

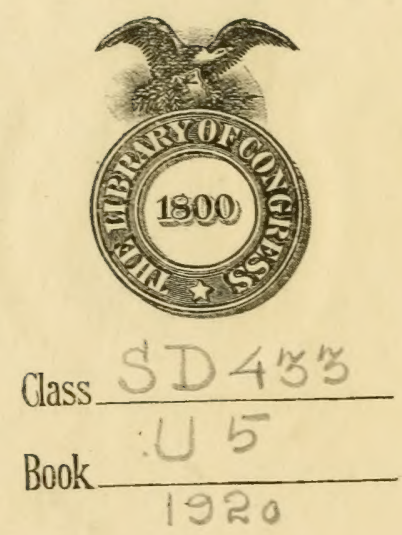






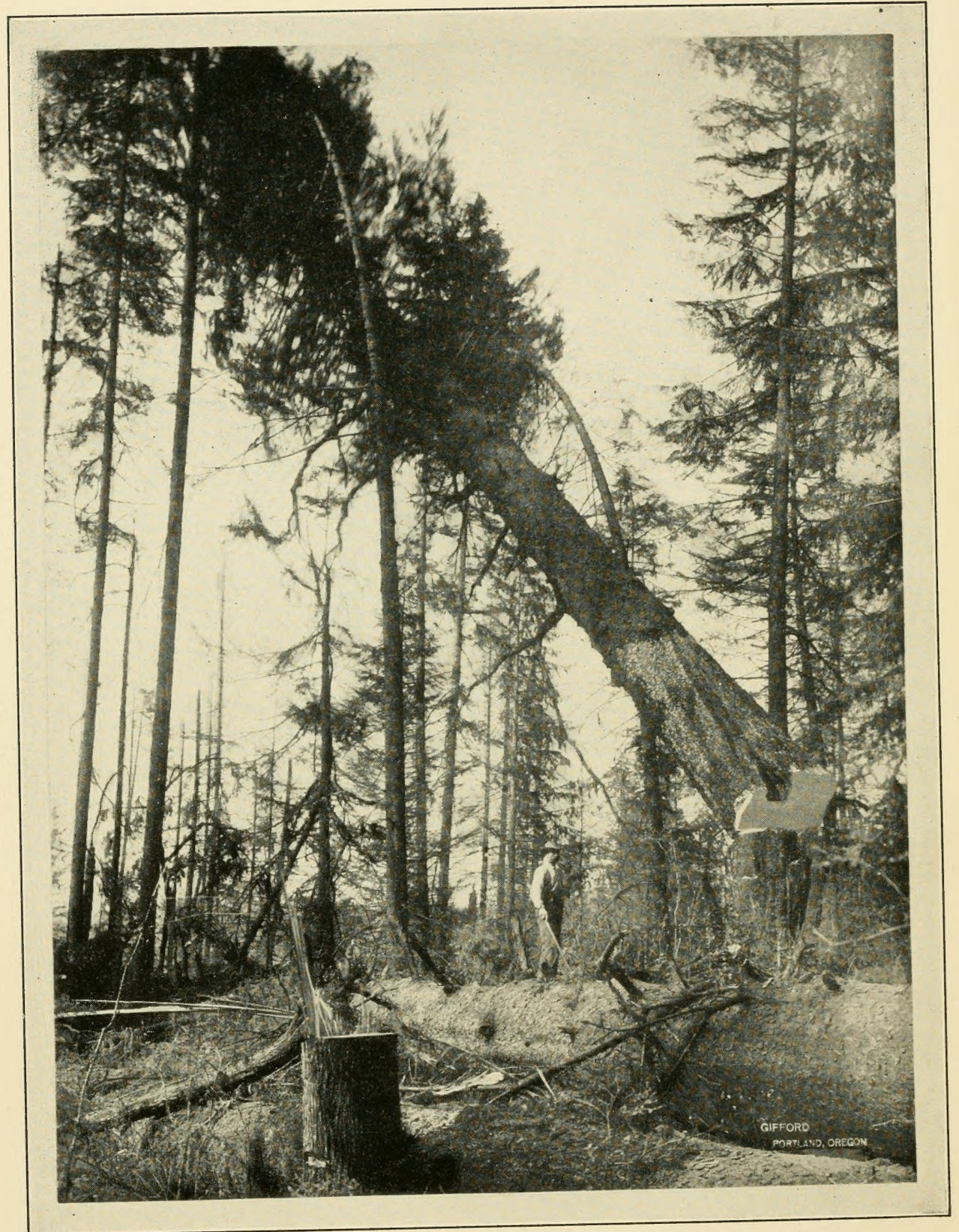

UTILIZATION-THE FIELD OF THE FOREST PRODUCTS LABORATORY BEGINS HERE 


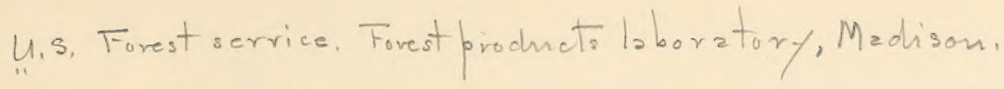

\title{
The Forest Products Laboratory
}

\section{A Decennial Record}

$1910 \quad--1920$

\author{
THE FOREST PRODUCTS LABORATORY \\ AN INSTITUTION OF INDUSTRIAL RESEARCH \\ MAINTAINED AT MADISON, WISCONSIN \\ IN QUARTERS FURNISHED BY THE UNIVERSITY OF WISCONSIN \\ BY THE \\ BRANCH OF RESEARCH \\ FOREST SERVICE \\ UNITED STATES DEPARTMENT OF AGRICULTURE
}




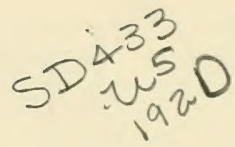

\section{LIBRARY OF CONGRESS \\ RECEIVED \\ JUL 201922 \\ DOQUMENTE PIVISION}<smiles>CCC1(C)CC[C@H]1C</smiles> 


\title{
GENERAL COMMITTEE \\ Decennial Celebration
}

FOREST PRODUCTS LABORATORY

\author{
MADISON, WISCONSIN \\ JULY 22 AND 23, 1920
}

Honorary Chairman,

Emanuel L. Philipe, Governor,

Commonwealth of Wisconsin.

Chairman,

HOWARD F. WEISS,

C. F. Burgess Laboratories, Madison,

Wis. Ex-Director, Forest Products La!oratory.

First Vice-Chairman,

Carlile P. Winslow, Director, Forest Products Laboratory.

Second Vice-Chairman,

H. J. ThORKELSON, Business Manager, University of Wisconsin.

Executive Secretary.

Don E. Mowry, General Secretary, Madison Association of Commerce.

R. H. Aishton, President,

American R.'R. Assn., Chicago, Ill.

W. R. ANDERSON, Publisher, "Packages,"

James R. ANgell, Chairman, National Research Council,

E. A. Birge, President, University of Wisconsin, Madison, Wis.

J. H. Bloedel, President, Bloedel-Donovan Lumber Mills, Seattle, Wash. Vice Pres. Nat'l Lumber Mfgrs. Ass'n.

C. S. Brantingham, President.

Emerson-Brantingham Co., Rockford, Ill. Chairman, Advisory Committee, National Implement \& Vehicle Association.

R. C. BRYANT,

Yale Forest School, New Haven, Conn. Pres. Society of American Foresters.

C. B. Chapman, President, Madison Association of Commerce.

Geo. M. Connwall, Editor and Publisher. "The Timberman," Portland, Ore.

Jos. H. Defrees, Defrees, Buckingham \& Eaton, Attorneys, Chicago, Ill. President Chamber of Commerce of U. S. A.

M. C. Fitzgerald. Director of Transportation, General Electric Co.,

A. L. Ford, Managing Editor,

Schenectady, N. Y.

"American Lumberman,"

I D Greago, Ill The Gardner-

W. A. Gilchrist, Chicago, III Chairman, Committee on Wood Utilization and Prevention of Waste. National Lumber Manufacturers'- Association.

JoHN M. GLenN, President, Glenn \& Co.,

Chicago, III. Secretary, Illinois Mfgrs. Association.

R. B. GOODMAN, Secretary, Sawyer Goodman Lumber Co., Marinette, Wis. Director, Nat'l Lumber Mfgrs. Ass'n.
Henry S. Graves, Washington, D. C. Former Forester, U. S. Forest Service.

W. K. Hatт, Purdue Univ., Lafayette, Ind. President Concrete Institute.

Chas. H. Herty, Editor, "Jour. Ind, and Eng. Chem.,"

New York, N. Y.

Howard W. HobBs,

Wood Mosaic Co., Inc., Louisville, Ky.

Willard C. Howe, President and Treasurer. Journal of Commerce Co., St. Louis, Mo.

B. F. Huntley, President, B. F. Huntley Furniture Co. Winston-Salem, N. C Chairman, Forest Products Laboratory Committee, So. Furn. Mfgrs. Ass'n.

Lovis T. JAmme, Chieago, Ill. Ex-V. P. and Chairman Civic-Ind. Com., Chicago Association of Commerce.

Elimer C. Jensen, Mundie \& Jensen, Architects, Chicago, Ill.

Bolling Arthur Johnson, Editor and Pub., "Lumber World Review," Chicago, Ill.

A. R. Joxce, First Vice-President, Joyce Watkins Co., Chicago, Ill. Pres., American Wood Preservers Ass'n.

C. F. Kettering, Dayton-Wright Branch, General Motors, Dayton, Ohio

James S. MACgRegor, United Aircraft Engineering Corporation, New York, N. Y.

B. F. Masters, V. P. \& Gen. Man.,

Rathborne Hair \& Ridgeway Company, Chicago, Ill.

Chairman of Bd. Nat'l Ass'n Box Mfgrs,

Harrt H. Merrick, President, Great Lakes Trust Co., Chicago, Ill. President, Mississippi Valley Association.

Geo. W. Mixter, Vice-President, Pierce-Arrow Motor Car Co., Buffalo, N. Y.

E. R. MOAK, Managing Editor, "Wisconsin State Journal," 'Madison, Wis.

L. D. Post. Publisher, "Paper Mill \& Pulp Wood News,"

New York, N. Y.

Percival Sheldon Ridsdale, Editor, "American Forestry," Washington, D. C.

F. J. SEnsEnBREnNer, First Vice-Pres., Kimberly-Clark Company, Neenah, Wis.

E. B. Stevens, President, Wood Products Co.,

Buffalo, N. Y.

W. H. Suldivan, Vice-Pres, \& Gen. Man., Great Southern Lumber Co., Bogalusa, La. Director, Nat'l Lumber Mfg. Ass'n.

David E. Town, General Manager, "Chicago Evening Post" and associated papers, Chicago, Ill.

R. F. Windoes, Editor, "Furniture Manufacturer and Artisan, Grand Rapids, Mich.

C. H. Worcester, President, C. H. Worcester Company, Chicago, Ill. Vice-Pres., Nat'l Lumber Mfgrs. Ass'n. 



\section{CON'TEN'TS}

Foreword

$$
\text { Patit I }
$$

CHAP'TER

PAGE

I Wood and Human Progress . . . . . . . 1

I I Early Perspectives of Forest C'tilization . • . . 4

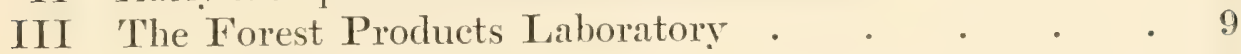

Establishment • . • • • . 9

Growth . . . . . . . . . 10

Organization . . . . . . . 12

Equipment . . . . . . . . 16

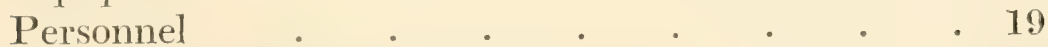

IV 'Ten Tears of Research in Forest Products . • . 23

Pre-war Research . . . . . . . 23

War Work . . . . . . . 37

$\checkmark$ Financial Value of Research Results . . . . . 59

VI Future Research in Forest Products . . . . . 63

VII How to Use the Laboratory . . . . . . 75

\section{PART II}

Decennial Foreword . . . . . . . 85

Decennial Celebration Program _ . . . . 86

Decennial Celebration Proceedings

General Assembly, July 22, 1920 . . . . . 87

H. F. Weiss, Chairman

Banquet, July 22, 1920 . . . . . . . . . 119

Burr TV. Jones. LL. D., 'Toastmaster'

General Assembly, July 23, 1920 . . • • . 139

John Foley, Chairman

Appendix

Decennial Registration List . • . • • . 179

Former Laboratory Staff Members _ . . . . 189 



\section{II.T.L'TRA'TIONS}

PAGE

Ltilization-The Field of the Forest Products Laboratory Begins Here . . . . . . . Frontispiece

Three Forester's, United States Forest Service . . . . 3

'The Yard to Which C'ome Iogs from Many Climes and Countries . . . . . . . . 8

Organization Chart, Forest Products Laboratory • • • . 14

Erection of the Million l'ound 'T'mber 'Testing Machine (1920) • 17

Three Directors, Forest Products Laboratory . . . . . 20

The Timber Mechanics Laboratory . . . . . . 24

Box 'Testing in the Big 'Tumbling Drum . . . . . . . 27

I ('harge of 'Ties Entering the Preservation (ylinder at the I al)oratory . . . . . . . . . 30

War Wrork-In Airplane Wring Rib Being Placed in a 'Testing Machine . . . . . . . . . . 36

Personnel Development Chart-July, 1917 to July, 1920 • 39

Laminated C'onstruction as Applied to Wooden Articles of Commerce . . . . . . . . . 44

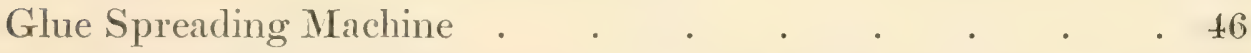

Some War 'Time Installations of 'Types of Dry Kins Dereloped at the Laboratory . . . . . . . . 50

Wood Distillation Retort . . . . . . . . . 56

Studying the Many Factor's Entering into the Manufacture and Storage of Airplane Propellers . . . . . . . 62

Forest Service Improvements in Turpentining . 68

Wood 'Technology-The Microscope is C'seful in Identification . 7? 


\section{IIILUSTRATIONS}

PAGE

'The ('ontrol and Operation End of a Dry Kiln at the Laboratory 76 Cooperative Box Work-A Study of Diagonal C'ompression 79

A Quiet Moment During the Decennial . . . . . 84

Fducational Work-A 'Typical C'lass in Kiln Drying . . 100

Timber Tests-A I arge Built-up Floor Bean Being 'Tested to

Destruction . . . . . . . . . 110

New Boxes for Old-Some War Time Box Work at the Laboratory . . . . . . . . . . 118

Notable Decennial Figures-Director $(-$. P. Winslow, Forester

W. B. Greeley, Former Director H. F. Weiss . . . 122

Bending Heavy Wheel Rims . . . . . . . 134

Ioisture Resistant Coatings-Applỵing Aluminum Leaf to

Wheel Pattern . . . . . . . . . 138

The Paper Making Machine . . . . . . . 142

A Corner of the Pulp and Paper Laboratory . . . . . 148

Notable Decennial Figures-Speakers and Leaders . 156

Iaboratory Helpers Gathering Data for Determining Moisture

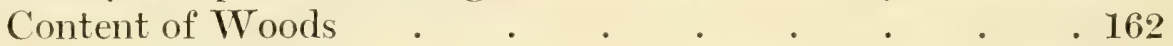

A Miracle of Chemistry-Conversion of Sawdust into Stock Food . . . . . . . . . . 170 


\section{FOREIVORD}

On July twenty-second, nineteen twenty, several hundred representatives of America's diversified woodusing industries assembled at Madison, Wisconsin, to celebrate the tenth anniversary of the founding of the Forest Products Laboratory. Men, representative of every important industry which draws upon the forests for its raw material, were present from throughout the United States. Several came from foreign countries.

The decennial celebration, of which the publication of this record is a part, was conceived as a mark of tribute to ten years of public service unique in the forest history of the world, and it was made possible by the contributions of over two hundred firms and individuals. Acknowledgment is here made by the committee for this striking evidence of good will, and the hope is expressed that this volume will reflect the spirit and character of the work of this institution during the first ten years of its public service. 

THE FOREST PRODLC'TS LABORATORY

A DECENNIAL RECORD

PART I 


\section{CHAP'TER I}

\section{WOOD AND HUMAN PROGRESS}

Knowledge is the torch of human progress. It throws its light forward and lifts each generation upward in the scale of civilization in proportion as that generation accepts its standards. In the story of creation, knowledge is symbolized by a tree. Down through the intervening ages man's use of wood in attaining new heights of knowledge has been one of the most important factors in the adrance of civilization.

Primitive man, we are told, was dominated by the forest. But as his crude imagination slowly awakened to the arts of life, he finally succeeded in reversing the order of his environment by making the forests more and more serve his material needs. And in conquering the forests, he built up the material structure of his own civilization: he stimulated his latent consciousness of the power of civilization; he lifted himself from a life of sarage and nomadic wandering to the social and industrial modernism of today.

History is rich in eridence of the achierement of human progress through knowledge derived from wood. Man, it is held, was rescued from a state of savagery primarily by two discoveries: the art of kindling fire at his will and the use of the bow and arrow, which made him master of his food supply and provided him with clothing. Ages later, the discovery of iron, with which he could fashion wood more and more to serve his needs, appears to have been the step from barharism to the first stages of cirilization.

It would be difficult to express proper appreciation of wood as a miterial stimulus to learning and the arts of living. Its ready adaptahility. we can well believe. made it the sculptor's clay by which man tested and developed his first imaginative theories and laid the primitive foundation of much present day science. The origin of the principle of the wheel, which is an essential part of almost every machine or mechanical converance of our own age, is lost in antiquity. as evi- 
denced by wooden wheels taken from the monuments of ancient Egypt. In these same mounds are found the earliest recorded form of plows, made from wood, with iron tipped wedges. With these plows man acquired his first crude knowledge of extensive agriculture, and he used them, with slight modifications, until the first half of the eighteenth century.

With wood, man learned to build homes and create architecture; to construct ships and master navigation; to build bridges and develop the science of mechanics; to generate steam and harness its power for transportation. MIodern electric and magnetic science owes its birth to fossil resin from coniferous forests which were prehistoric when Pliny, seventy years before the dawn of Christianity, recorded the fact that amber, when rubbed, acquired the power of attracting straws. Thus, in diverse ways, fundamental principles have first been worked out from wood, and the knowledge thus gained-primitive though it may now appear - has been applied in developing the use of stone, iron, steel, concrete and other materials. The process still goes on. Within a decade, man has conquered the air with a wooden plane and is today applying the results of his experiments to the fabrication of an all metal machine.

It is a striking fact that through the agency of wood, man has acquired more fundamental knowledge of related subjects than he has of the properties of wood itself. In the development of his wood craft, he has been likened to the growing child who, building with blocks, acquires an erer larger consciousness of their adaptability to new figures as experience matures his mind. Spurred by personal needs and the rewards of commercialism. howerer, man fashioned wood into many scores of standard products, about which trade-crafts took shape and became clearly defined through many centuries of competition and zealous individualism. He thus built up a great diversified mass of wood-using lore, based, not upon a scientific knowledge of the many different kinds of wood used, but upon rule of thumb methods, beliefs, customs and prejudices, passed down from one generation to another as expanded by the increasing complexities of each changing age.

Into this accumulated mass of trade practices, business methods, and usages built up through the years, there was injected, even up to 


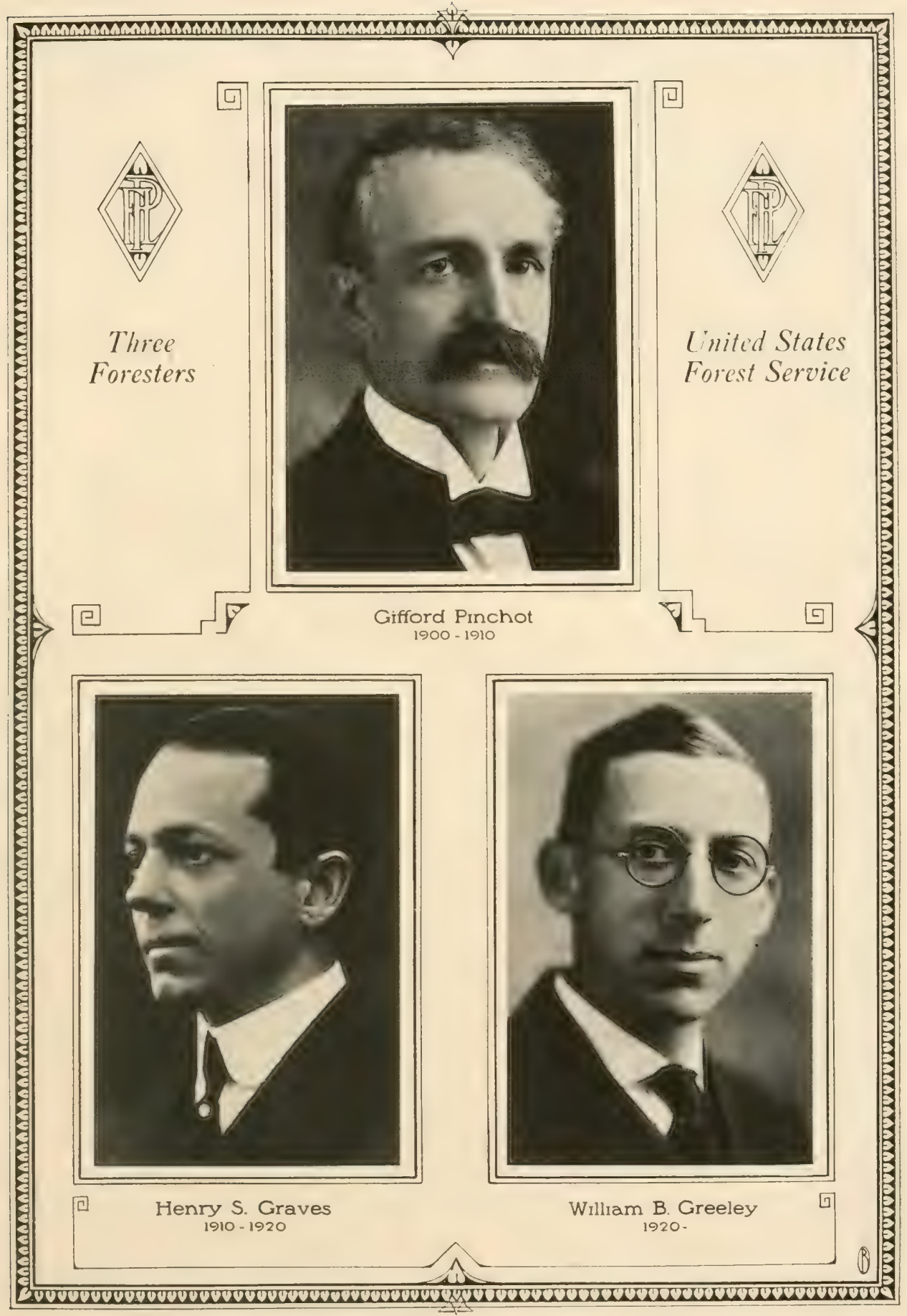


the begimning of our present century. little knowledge derived from pure scientific research into wood products and the wood products industries. However, by that time certain forces were well under way that were destined shortly to produce results and create an entirely new factor in the field of wood-using trade methods of America, and other countries also.

\section{CHAP'IER II}

\section{EARLT PERSPECTIVES OF FOREST L'TILIZATION}

Abundant forests have made the United States the greatest wood-using nation of the world, but they have made it also the greatest wood waster of the world. Our lumbering practice has been built upon supplying the best the forest affords and leaving the rest as waste. Our forefathers commenced the practice because they had more forests than they knew how to use. Pioneers, moving westward, continued the system. And lumber consumers, educated to expect the best, continued to demand the best. Thus the great dictator of forest utilization in this country has been custom instead of specialized knowledge of the properties of our different woods. The power of knowledge has been capitalized in a mechanical science for converting forests into lumber and manufactured products, a science which is unsurpassed anywhere in the world, and which has made wood available in a greater variety of forms than any other material with which man comes in contact. It has made wood, as Roosevelt asserted, an indispensable part of the structure upon which our civilization rests, but its ready convertibility to man's multitudinous needs appears to have held passive. so long as forests seemed inexhaustible, the stimulus to study its properties.

The world today very generally accepts the view that forests are essential to progress and to social and industrial supremacy. The 
culture of the forest-stared regions of Europe leares, in the minds of those who have had opportunities to make comparisons, no doubt that there is a point below which forests can not safely be reduced. Europe itself recognized that fact several centuries ago, but America, with its boundless forests, once thought inexhaustible, is just beginning fully to awaken to the cause of forest conservation espoused in this country a few decades ago by a small group of far-seeing men. 'The present Forest Service, a bureau of the U'nited States Department of Agriculture, is the outgrowth of the study, thought and efforts of these men.

'Their purposes, howerer, were much opposed and misunderstood from the start. A common misconception was that they proposed to lock up the forests against use; whereas what they sought was to replace heedless and wasteful exploitation by rational management of the forests and by rational utilization of their products. They spoke from the experience of older countries and urged the application of knowledge then arailable as well as the acquirement of an additional knowledge needed to put our forest lands and our wood crops to their highest use in perpetuity. They stressed the forest management that they had learned from Europe. but they did not fail to recognize that a knowledge of the properties of our many different woods is fundamental to the economical utilization and conservation of our forest resources.

In the report of the Division of Forestry for the year 1887. B. E. Fernow, Chief of the Division, wrote:

"The properties upon which the use of wood. its techmologr. is hased, should be well known to the forest manager if he wishes to produce a crop of given quality useful for definite purposes. Our ignorance in this direction has been most fruitful in fostering a wasteful use of our natural forests, and the same ignorance misleads even the forest planter of today in choosing the timber he plants and the locality to which he adapts it. How the Black IValnut has been sacrificed for fence material, how the raluable Chestnut Oak has rotted in the forest unused, how the Hemlock has been despised and passed by when it might have been successfully used to lengthen the duration of White Pine supplies, how timbers are now used in unnecessarily large sizes and applied 
to uses for which they are not adapted, while other timbers are neglected for uses for which they are adapted-all these unfortunate misapplications are or have been due to lack of knowledge of the technological properties of our timbers.

"Every day, almost, brings to light a new use for this or that timber, every now and then lumber papers are weighing the serviceability of this or that wood. Instead of proceeding on a sure and scientific basis in recommending the application of any wood to a particular use, opinions pro and con are brought to bear, and the proper development of our resources is thereby retarded. Yesterday it was Redwood that needed commendation in the market, today it is Cypress that must be praised in order to receive due appreciation. Our timbers have never been fairly tested, or if ther have their qualities are not duly appreciated. Many kinds have their use and ralue still hardly recognized; woods of exceptional value for manufacturing purposes are consumed for fuel; valuable and scarce varieties are used for coarse work, while cheaper and more abundant sorts are available. Still less knowledge exists in regard to the conditions of growth which influence the quality of woods. Crude 'experience' has been our guide, and 'crude' has remained our 'knowledge'.'

Fifteen rears later. Theodore Rooserelt, then President, broke all presidential precedents by addressing. at a private home in Washington, a meeting of the Society of American Foresters, an organization which embraced the handful of American foresters of that time. During his talk, he said:

"And now, first and foremost, you can never afford to forget for one moment what is the object of our forest policy. That object is not to preserve the forests because they are beautiful, though that is good in itself, nor because they are refuges for the wild creatures of the wilderness, though that, too, is good in itself ; but the primary object of our forest policy, as of the land policy of the United States, is the making of prosperous homes. It is part of the traditional policy of home making of our country. Every other consideration comes as secondary. 'The whole effort of the Government in dealing with the forests must be directed to this end, keeping in view the fact that it is not only necessary to start the homes as prosperous, but to keep them so. That is 
why the forests have got to be kept. You can start a prosperous home by destroying the forests, but you can not keep it prosperous that way. . . . 'Forestry is the preservation of forests by wise use?,"

In the midst of timber plenty, the work of early pioneers to advance the cause of forestry in this country belied itself to many, but in the years that followed, the rapidly enlarging spectacle of forest devastation accompanied by growing scarcity and increasing prices of wood, left in doubt no longer the accuracy of their vision or the justice of their endearor's. Today the problem of forest conservation stands out as one of the most vital economic issues of the nation. Knowledge accumulated during the past thirty rears has served to crystalize the problem, for it is now generally conceded that its solution lies along two main lines of endeavor: the first is by stopping further devastation through such measures as will afford adequate protection and regulation of our remaining forests and will put our forestbearing lands on a permanent forest producing basis; the second is the curtailment of the annual drain upon the remaining forests by more complete and scientific use of the trees cut, a use arrived at by an accurate knowledge of the properties of the rarious woods and their economic use. 


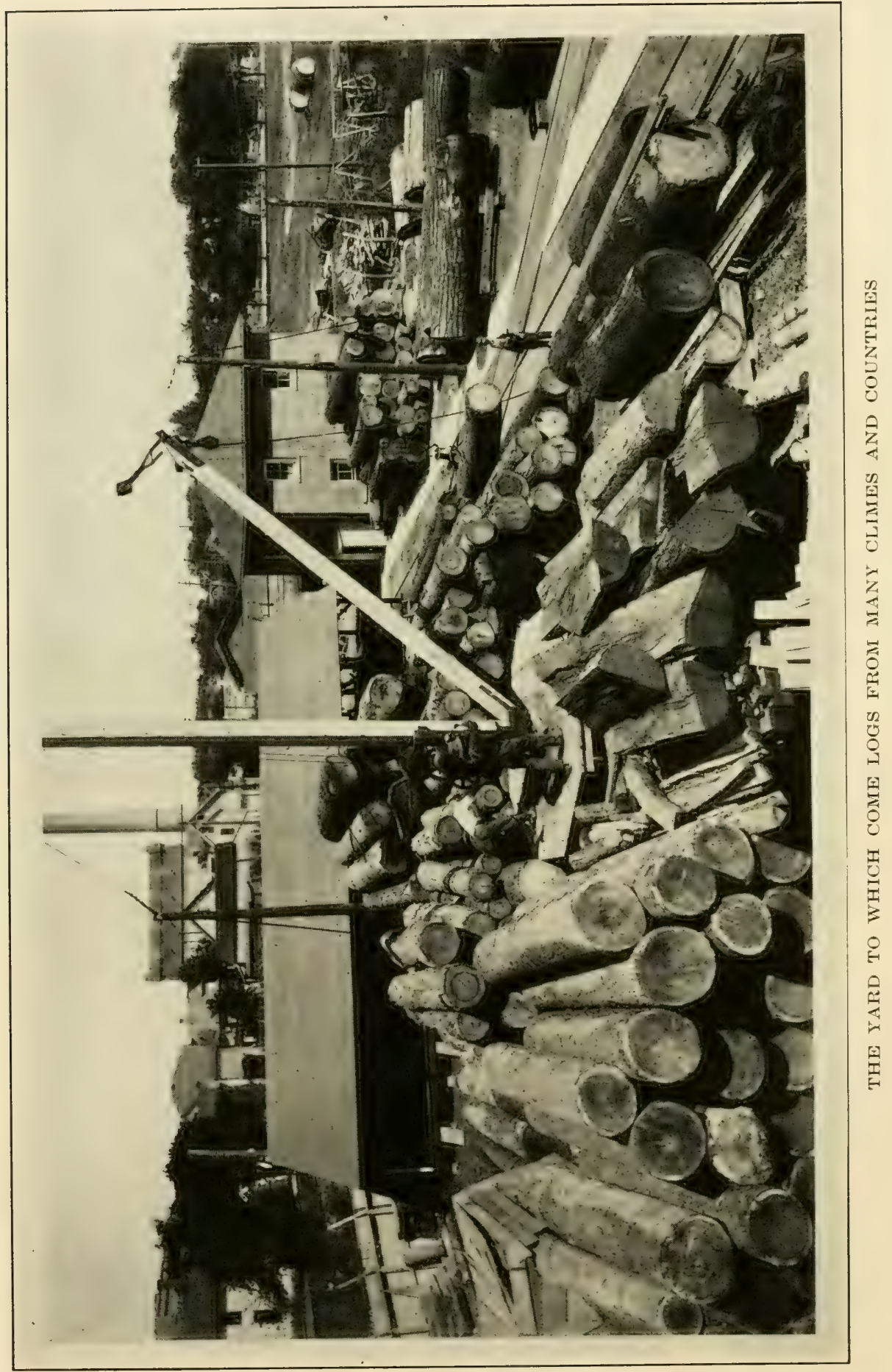




\section{CHAP'TER III}

\section{THE FORES'T PRODL'C'TS LABORATORY}

\section{Estiblishamext}

'The national need for research in forest products was recognized from the earliest days of the Dirision of Forestry and became increasingly apparent as forest exhaustion in the east adranced. Eventually it asserted itself. 'The scanty appropriations of the first decade of Anerican gorernmental forestry provided little money for research in forest products, and between 1890 and 1910 work was mainly of a cooperative nature and was done largely at various universities where laboratory facilities were obtainable or buildings were available for housing testing equipment.

Studies of the mechanical properties of the more important woods were begun at the universities of Washington, Yale, Purdue, California, and Oregon. Some preservation and kiln drying studies were undertaken at Yale, research in naval stores initiated in the South, and a small experimental pulp mill erected in Boston. Wood chemistry and the chemistry of wood preservatives were also handled in a limited way at this latter place in $\mathbf{1 9 0 7}$.

During the following two years it became increasingly evident that greater facilities for research would have to be provided, and that centralization was essential to the success of the work. The very nature of research demands coordination of all related facts and studies, and this coordination is difficult to secure without centralization of allied research agencies.

A very large part of the research work of the Forest Service had been carried out in cooperation with various universities, which had been glad to place some of their facilities at the disposal of the service. and so it was natural that, in the need for increased facilities, thought should be given to the universities. A thorough canvass of Washington had already shown the utter futility of trying to rent suitable quarters for the small sum available. 
A survey of arailable and potential facilities at a number of the unirersities was therefore made. An unexpectedly large number of universities showed a keen interest, and very generous offer's were made by several. Finally, the offer of the Lniversity of Wisconsin, which included the erection of a suitable building and the furnishing of heat, light, and power for it, was accepted. Construction started in the summer of 1909, and the installation of equipment was begun in the fall, shortly after the nucleus of the organization arrived from Washington and established temporary quarters.

At the time of the formal opening. June 4,1910 , the personnel consisted of about 45 people, drawn from the various lines of work under way elsewhere. Much of the credit for the progress of the laboratory belongs to the small group of loyal and enthusiastic workers comprising the original staff of the laboratory. They are the ones who laid down the general plans for the fundamental researches, worked out the details of procedure, and designed much of the special apparatus and machinery which was required for the preparation of the specimens and the carrying out of the tests. These preliminaries having been worked out, they proceeded to obtain the groundwork of information upon which most of the war work and the majority of the later general and special studies were based.

\section{Growth}

The first years of the laboratory's existence were deroted to the task of getting the plant running and obtaining a grasp of fundamentals. No marked increases in appropriations were secured. and expansion was comparatively slow. It was possible, howerer, to broaden the scope of the work gradually, and to establish satisfactory contact with the principal forest products industries.

When the United States entered the war in the spring of 1917, the laboratory staff numbered eighty-four persons, a mass of fundamental data on the properties of wood had been accumulated and good contact with the wood-using industries had been established. Thus equipped, the laboratory immediately bent all its efforts to war work, recognizing that the wood would play a major part in the conflict. It immediately made its knowledge and facilities available to all the other branches of the government which had need of them. An 
analysis of the entire wood and forest products situation, from the standpoint of war needs, was begun at once, and steps were taken to secure the rast amount of information which this analysis showed would be needed by the War and Navy Departments.

Contact was established with the rarious branches of these departments and others doing war work, and systematic cooperation undertaken. Funds were made arailable by the cooperating departments, and the personnel of the laboratory was increased as rapidly as men could be trained for the specialized work. This expansion continued throughout the war, and on armistice day the force numbered 458.

Many of the problems presented to the laboratory were solved immediately with the knowledge available. Others were of new and specialized character and required the construction of special machinery and the making of many special tests. The experience and the vision of the older men in the rarious branches of the work proved to be invaluable in the planning and execution of these special investigations. It is safe to say that a large measure of the usefulness of the laboratory during the war would have been lost had these men, instead of remaining in the organization. answered the many calls to other fields and gone where greater financial reward and personal gain would have resulted.

Many developments of the war, new inventions and new processes, chemical and physsical, born under the stimulus of war necessity and deroted to military use were found after the armistice to be of value in peace times industry, either with or without modifications.

In the poison gas campaign normal time industry profited by discoreries that, lacking the stress of national emergency, might not have come in years of derelopment.

The unbelievable progress in aeronautics in a brief four years. at once, upon the cessation of hostilities, was converted to commercial. sporting and other transportation, such, for instance, as the mails. The same thing happened in many fields, among them forest products research.

During the war, no effort had been made to publish and distribute the results of the laboratory's researches.-in fact. a rery large percentage of the war work was secret and confidential and did not permit of publication. Special effort has since been made by the entire or- 
ganization to disseminate as much of the accumulated information as has useful application among the industries.

The re-establishment of many of the contacts, which were broken during the war, was undertaken, and fundamental researches, temporarily laid aside, were resumed. Plans were perfected for further study of several new lines of research undertaken during the war, and for rounding out the investigative program of the laboratory.

\section{Organization}

The laboratory is organized upon a basis intended to yield the greatest measure of scientific results with the minimum amount of time and energy devoted to the mere mechanics of operation, and the routine of the organization is centered almost entirely in separate service sections; so that the research men may be reliered, as much as possible, from everything except the planning and execution of research investigations. This type of organization has proved itself very well adapted to research institutions, since, in the final analysis, the success of a research institution depends in greater measure, than is the case with most organizations, upon the individuals composing its staff. Research is most individualistic; and while it is possible for the leaders in the organization to plan and direct the research of the various men, the success of each project depends to an unusual degree upon the man immediately in charge of it.

The technical work of the laboratory is divided among seren sections, each of these units devoting its investigations to certain well defined fields. In addition to the research sections there are four service units carrying on the many functions, such as finance, engineering, maintenance, personnel details and so forth, essential to the smooth working of an organization of the size of the laboratory. In these service units is grouped for convenience the office that handles the editorial work, and to this office is assigned the responsibility for the general dissemination of the results of all the laboratory's research. Every effort is made to reach the entire wood industrial field through a variety of mediums. Coordination of research activities is handled through a small subdivision, tributary to the director's 
office, acting as a balance wheel or gorernor to the entire program of the research portion of the laboratory.

To one interested in getting a more intimate grasp of the laboratory organization scheme a stuly of the chart on the following page will serve better than a descriptive effort. Further, there can be gained from this chart a good general idea of the main lines of research pursued at the present time (1921).

\section{Forest Service Products Offices}

A discussion of the organization of the Forest Products Iab)oratory would not be complete without mentioning the forest products offices in sereral of the headquarters of the western districts of the Forest Service. While not a part of the Madison organization, their work is intimately tied in with the laboratory through chiefly furnishing a close contact with the industries in the sereral districts.

The offices of the District Forester's at Missoula, San Francisco and Portland are assigned one or more men to handle the work in this field that occurs within the states covered by these offices. Reporting to the District Forester at Portland there is also a timber testing laboratory maintained in cooperation with the University of Washington. at Seattle, which works on local problems referred to it directly or indirectly.

The persomel of the district products offices offers broader outlets, in somewhat remote regions, for the work of the laboratory than otherwise would prevail.

Irandling many local problems directly on the ground the field men are also enabled to rapidly oltain for the industries information or special inrestigations from the laboratory through interior organization channels. To these same offices the laboratory in turn occasionally refers problems that can be handled better in the field. The relationship, in the final analysis, is the logical outcome of the inseparable tie that the development of forest products utilization, represented by the laboratory, has to the silvicultural and management aspects of national forestry practice in this country. 


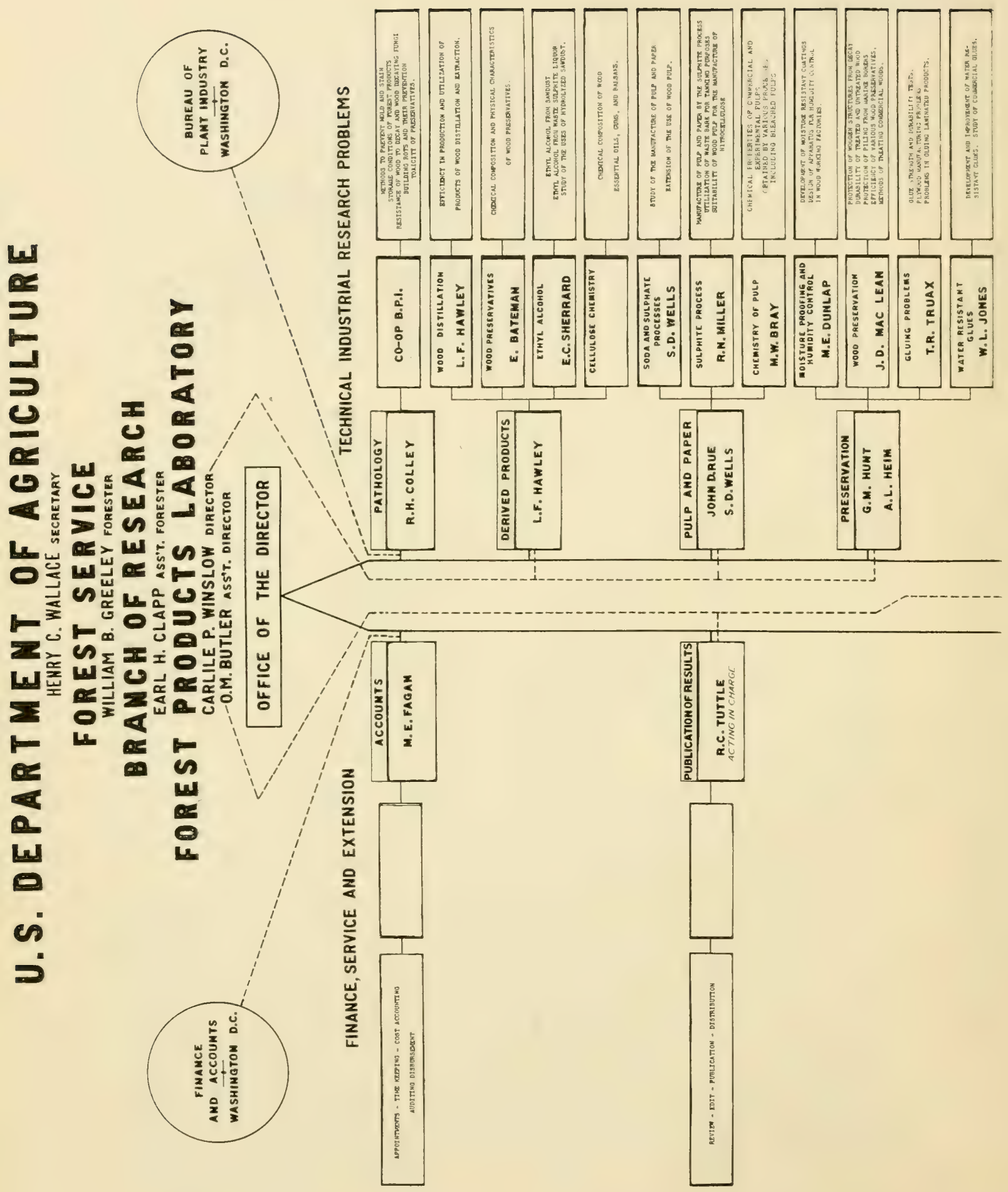




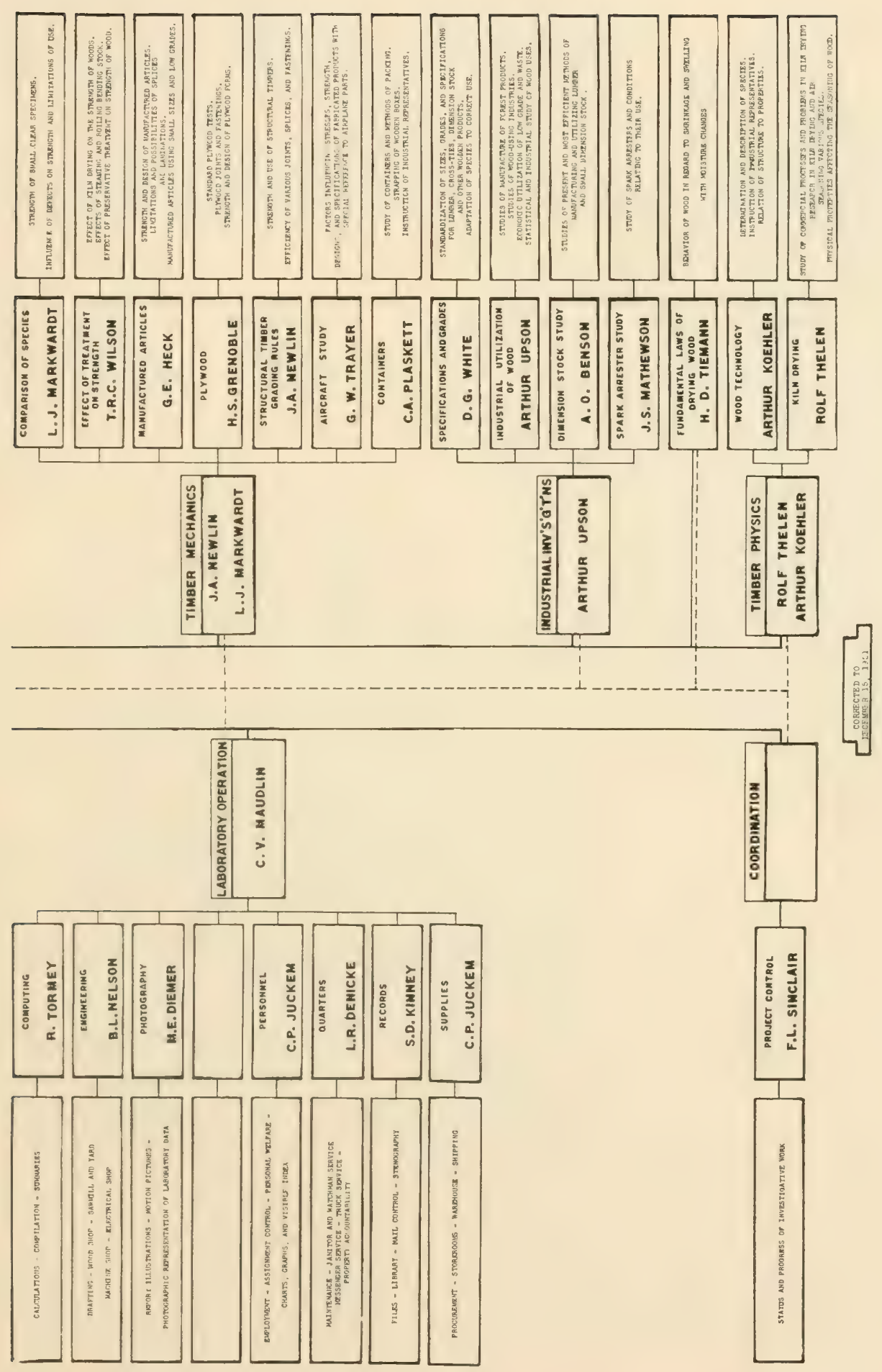




\section{Equipanest}

Mr. Howard Weiss, director of the laboratory from 1912 to 1917, tells the following story of conditions prior to the establishment of the laboratory :

"At that time I was in the office of Wood Preservation, and was in charge of the Section of Research, which consisted of myself and the title. Since we had no permanent laboratory, we had to more around from place to place with what little equipment we could gather together.

"It was about this time that I was sent to the great Southern Lumber Company at Bogalusa, La., to show them how to preserve timber. All I had was two galvanized iron tanks which I had had made at a cost of about $\$ 20$ each.'

From this meager outfit has grown the present thoroughly equipped section of wood preservation at the laboratory, with a large pressure treating plant handling several dozen ties at a charge, smaller pressure cylinders, one of which is capable of injecting preservatives at a pressure of 600 pounds to the square inch. and much auxiliary and special apparatus permitting carrying on of preservative treatments according to any commercial or experimental process.

Handling as it does the glue and laminated wood studies, the section of preservation is also suitably equipped with glue mixing and spreading machines, hot and cold presses, strength test machines, an aircraft propeller manufacturing plant and a series of conditioning rooms where temperature and humidity are under control.

'The first efforts at wood testing in this country were strength tests on timbers of several species of American woods. In this sense one may say that the study of timber mechanics of wood was the leading field of research. Today the equipment of this important part of the laboratory is especially complete, and most of the equipment was designed by the laboratory engineers.

A timber thirty feet in length is readily accommodated in the capacious jaws of the new million-pound testing machine recently erected as part of the equipment of the timber mechanics laboratory. This same giant of wood breakers will test the strength of horizontal, built-up beams, trusses and girders with a length as great as eighty 


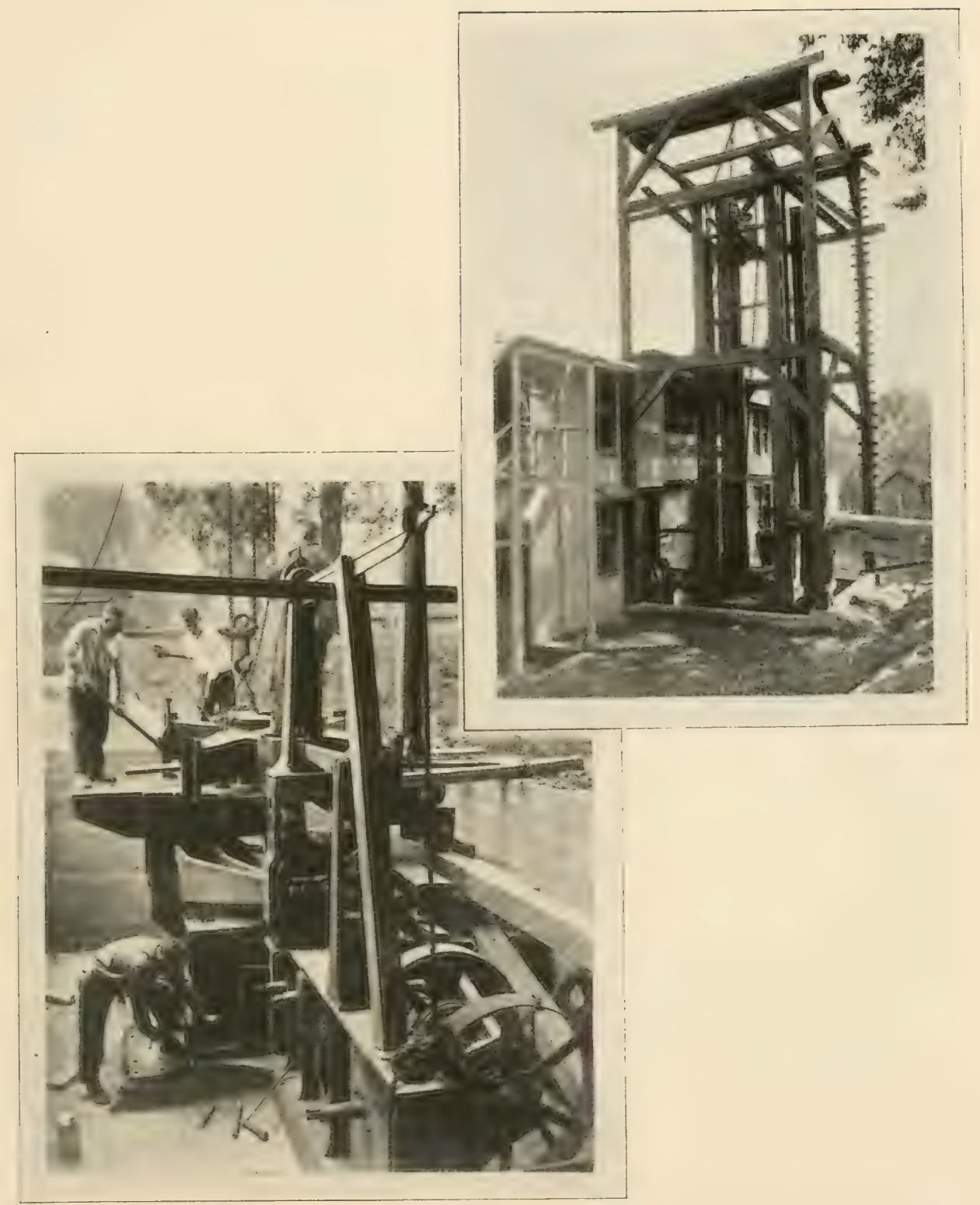

ERECTION OF THE MILLION POUND TMIEER TESTING MACHINE (1920) 
feet. While this indicates the maximum capacity of the Forest Products Laboratory to test timbers and huge built-up members, the equipment for lesser parts is especially complete. 'Ten machines capable of applying breaking strains of from 10,000 to 200,000 pounds are also arailable. Toughness and impact resistance are measured on other machines, while many special tools and rigs are here for special tests, including those for testing plywoods. Most of these machines are original derices that first saw the light of day in the laboratory as need for them arose in the progress of the development of the technique of testing wood.

The box laboratory, a part of the work of timber mechanics, is equipped with two tumbling drums, the larger of which can take boxes weighing as much as half a ton, and reduce them slowly or quickly to a shattered wreck-the quickness of the breaking depending on the amount of resistance built into the box by its designers. Here also can be measured the ability of a box to stand tension and compression, drop tests and similar abuse.

The drying of wood by almost any conceivable variation of temperature, humidity and circulation within practical limits is possible in the laboratory equipment of six dry kilns of commercial size, all closely regulated and entirely automatic and autographic in their operation. In addition to the kilns, a conditioning apparatus permits fundamental research in the conditioning and treating of wood under pressures or gases, and under absolutely controlled factors. This apparatus, as well as the kilns and many supplemental devices, was designed by laboratory engineers.

Completely equipped to make wood pulp by any of the commercial chemical or mechanical processes and convert the pulp into paper by crlinder or Fourdrinier process, the pulp and paper section measures up to the general standards of equipment existing throughout the laboratory. The list of equipment sounds like a combination of several paper-making plants, but of course everything is on a laboratory rather than on a commercial scale. The main items recognizable by the paper manufacturer are a wood chipper, sulphite and soda digesters and necessary auxiliaries, grinder, pulp press, wet machine, beaters, Jordan and a 22-inch combination cylinder and Fourdrinier papermaking machine. Pressers, driers, colender's, etc., complete the list. In addition to complete chemical equipment, a constant humidity and 
temperature room is maintained for strength tests on the finished products.

'The section deroted to derived products, dealing with the many phases of the chemistry of wood. carries as its working tools the usual chemical laboratory equipment. Much special equipment is used, especially instruments for measuring accurately the various physical and chemical properties of oils, sugars and solutions. Specialized equipment consists of complete semi-commercial plants for production of ethyl alcohol and stock food from sawdust; destructive distillation of hardwoods and softwoods; the extraction with rolatile solvents of resinous woods, waste paper products and other materials.

Pathological work, largely a study of fungi and their effect on wood in many fields of use and from many viewpoints, is carried on by a cooperating office of the Bureau of Plant Industry. The equipment for the work is complete, consisting of all necessary apparatus and mediums for studying fungi under various conditions. Included in the working equipment are pure culture samples of various wood fungi used for comparative studies.

The enumeration of this sundry physical equipment of the laboratory is made mainly to outline briefly to the prospective user, the man with a wood problem but unacquainted with the laboratory, what can be expected in the way of a capacity to handle that problem. The enumeration also indicates the growth in the science of wood technology and research in ten years, for it must he remembered that at the time of the establishment of the laboratory, an uncharted sea lay before the routhful explorer. Truch of the complex testing machinery in use at the laboratory stands as a marker or buoy in the portion of the unknown that has been charted. A rast and unlimited field ret remains ahead.

\section{Personnel}

It has been said that an institution is but the lengthened shadow of a great man. The laboratory, from its rather composite nature. more properly, as it stands today, is the lengthened shadow of many men. To its establishment and to its development many men have contributed the best that they had to give. The strength of the laboratory in its own particular field, after the brief lapse of ten years, 


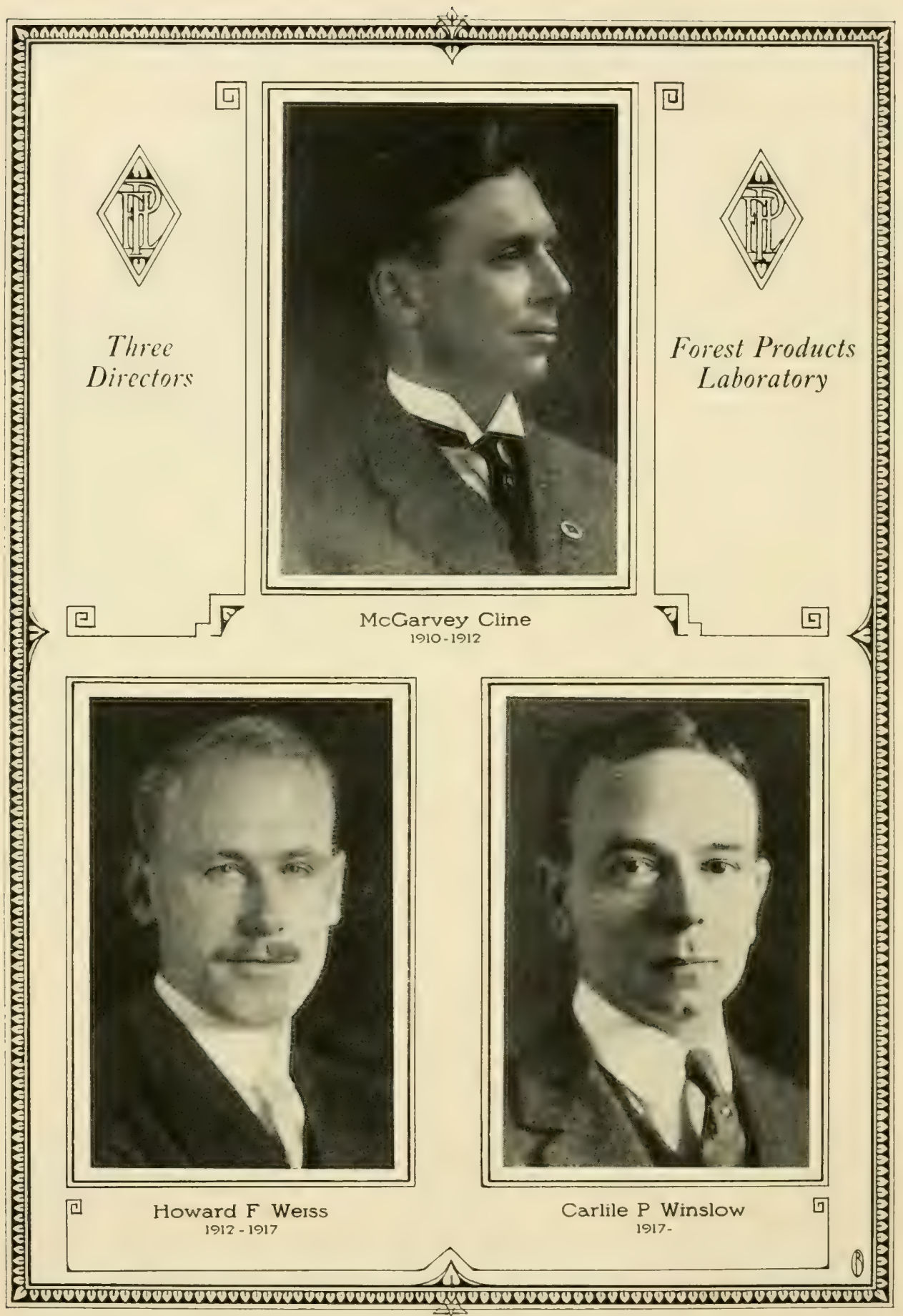


testifies that this best was no mean gift. Recognition of the ability of the men who have been associated with the laboratory by industries, by technical societies, by great industrial associations and by the govermments of this and other countries is a part of the record of the laboratory that in itself would require much space to tell.

It has been told elsewhere that the need for the laboratory was recognized for many years before its creation actually became a physical fact. Of interest are the first steps in forest products research, first only a man or two with ideas, then the establishment of small scattered units working on big problems with but meager equipment and limited means usually nearest the point where the problem existed. 'The realization grew upon some of these pioneers that problems of nation-wide interest involving many industries were being most inadequately provided for, and little progress being made toward faroff goals. 'The evolution of a new approach toward the desired ends marked the important step that is of chief interest in the story of the Decennial. Mr. Howard F. Weiss saw the germ of the present laboratory conceived and described it in an address to members of the laboratory several years ago.

"It was in 1908 that I was brought face to face with the foolishness of the whole situation. I felt like a very poor representative of the greatest government on earth in thus trying to demonstrate the art of preserving timber with a lack of funds for effective organization.

"It was in Washington that I met McGarrey Cline who was hatring similar difficulties although engaged in a somewhat different line of work. Many an evening we spent discussing possible ways of putting into execution the plan of equipping a suitable laboratory. with the lack of funds always confronting us. Our first ground gained was permission to spend $\$ 125$ per month for renting a building in which we might locate the laboratory. 'The jol fell to me to find a building for this purpose. I spent many weeks going from Chery ('hase to Great Falls and all through Georgetown, looking up buildings with sufficient floor space, and which could be rented at $\$ 12.5$ per month. I was unable even to get an abandoned car barn for this amount.

"Then Cline conceived a brilliant idea. It was to secure the cooperation of some university. I did not think this was a very 
good move but the more we talked it orer, the more I became in favor of it. We carried the proposition to $\mathrm{Mr}$. Pinchot, the Forester, who was favorably impressed with the idea and wrote to about a dozen universities suggesting the scheme to them. The idea met with hearty approval and resulted in establishing the Forest Products Laboratory at Madison in cooperation with the University of Wisconsin, the Unirersity to furnish the building, heat, light and power.

"The credit for this organization belongs to Mr. Cline, as he was the one who actually conceived the idea and put it into operation.

"Then came the struggle to equip the place for which we had little money. I had $\$ 120$ alloted to me to equip the section of Wood Preservation, in which I was specializing, and it required $\$ 3,200$ to install the machinery which I wanted."

Under these handicaps the first men of the laboratory laid the foundation upon which the present structure has its footing. McGrarvey Cline served as the first director of the institution in whose founding he had such an important hand, learing in 1912 to enter commercial life after the work was well established.

Others who played leading roles in the work of the early days when the laboratory was still in the formative state were Mr. William L. Hall, who, as Assistant Forester, had administrative charge of the laboratory in the days immediately following its inception and Dr. IV. K. Hatt of the Purdue ['nirersity faculty, at one time in charge of all timber test work for the Forest Service and later acting in a consulting capacity on various features of the work, especially in timber mechanics. Through the days of the war emergency, Mr. Earl H. Clapp was the Assistant Forester in charge of the Branch of Research of which the laboratory is a unit.

Possibly the best measure of the worth of the laboratory is an estimate of the practical value of the research results. These have been described elsewhere in this volume. The next measure is an estimate of the caliber of the men that make up its personnel. To a degree, the two are naturally inseparably related. The record of the requests made by wood using industries and other points of laboratory contact, for laboratory men to transfer their allegiance to these other fields speaks well for the ability of the men who have served here. A 
list of such men who have left the technical staff of the laboratory for other fields is given in the appendix to this volume.

\section{CHAP'TER IV}

\section{TEN YEARS OF RESEARCH IN FOREST PRODCCTS}

The decade following the founding of the Forest Products Laboratory in 1910 is marked by a convulsive upheaval.-economic, social and political,--msurpassed in modem history. In the Lnited States, at least, the ten-year period is now commonly divided into the eras "the pre-war years", "during the war", and "the post-war period". 'The latter is, of course, only begun, but a definite readjustment and new alignment of economic forces is already in the making.

So in discussing the laboratory development, and particularly the field of its accomplishments, the descriptive effort naturally falls into the cycles: pre-war six years, war period of two years, and the readjustment or post-war period of two years. The first two are here treated in some detail; the latter period and its outstanding features has already been discussed.

\section{Pre-war Research}

'The early work of the laboratory was largely fundamental in character, and was, in many instances, a continuation of investigations which had been under way at one or more of the various smaller laboratories which were discontinued when the Forest Products Laboratory was organized. In fact, full credit for some of the accomplishments described in this chapter belongs to the pioneers of those early days, who struggled along in the dark with practically no fundamental knowledge of the properties of wood to guide them. 


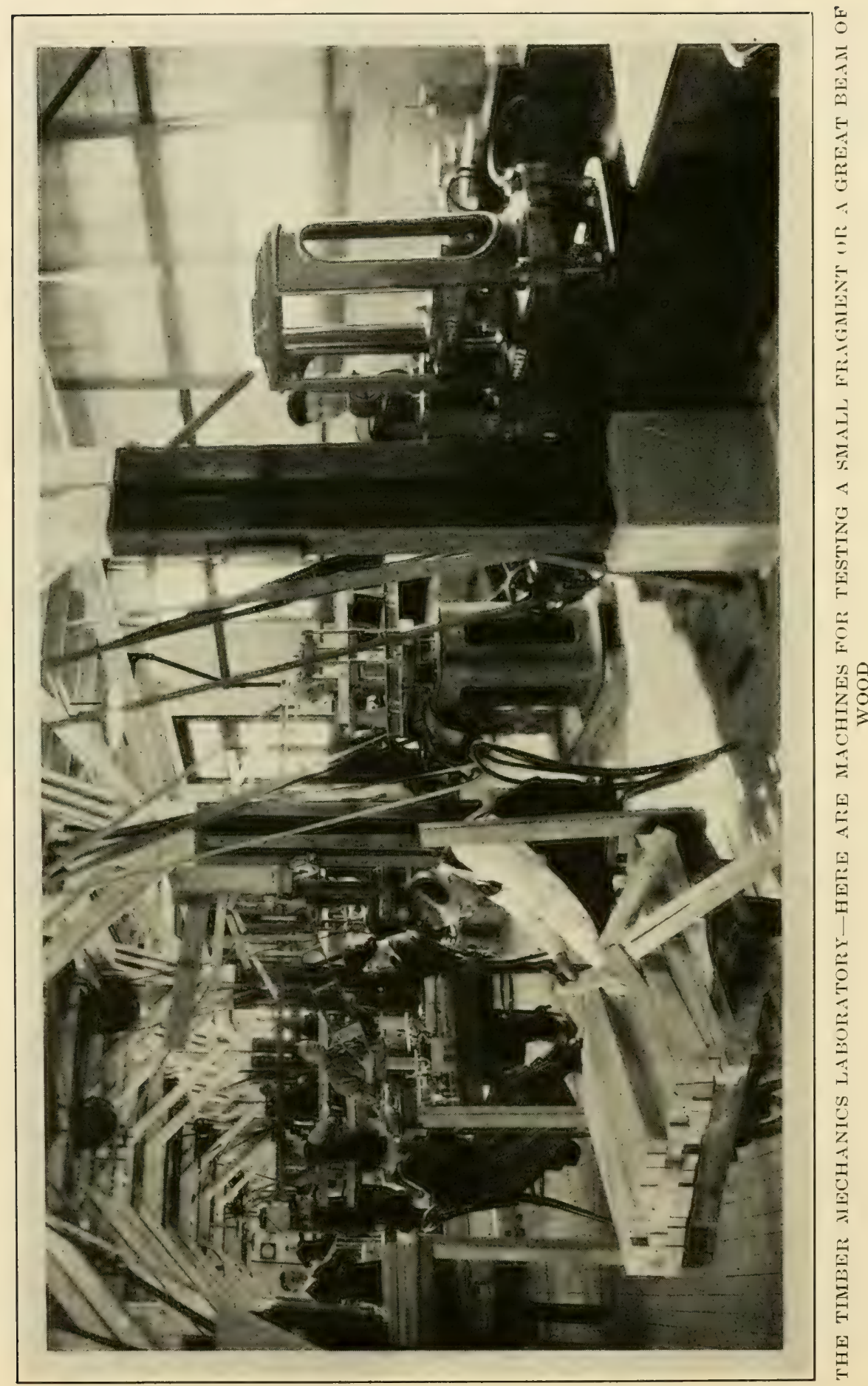




\section{In the Mechanics of Timber}

While no attempt has been made to arrange the various subjects in order of size or importance. it seems natural and logical to give first mention to the basic study of the properties of American woods. 'This is. without doulst, the most important series of tests erer conducted on American species, not only in actual size, but also in importance of results secured. Orer 200.000 strength tests and about the same number of specific grarity and moisture determinations, in all well orer half a million individual tests, have been made. covering every commercial species in the country and many of only minor importance. The tests were made on specimens cut from typical trees and were so planned and executed that proper analysis of the results has yielded. hesides actual and comparative strength values of green and air-dry wood of the various species. much additional information of fundamental character, such as the relation of strength to weight of strength to the height in the tree, the effect of distance from the pith upon the strength properties, and the relation between strength and rate of growth.

'The test data are frequently used for special studies, being regrouped and analyzed to bring out whatever unusual property or relation of properties may he desired. 'They form the starting point. also. for much of the experimental work upon structural material and parts of structures, such as aircraft parts.

Work of previous experimenters has shown that the amount of moisture present in the wood had a rery marked effect upon its strength. and efforts had been made to deduce the laws underlying this relation. It remained for the timber testing laboratory at Ýale to plan and carry out a series of tests which not only yielded specific data on the moisture-strength relation for sereral species, but also proved the existence of a definite point. now called the "fiber-saturation point", beyond which the amount of moisture did not affect either strength or shrinkage. This basic information is in constant use in all of the studies of the mechanical and physical properties of wood.

'The requirements for grading rules for structural timbers differ from those for rough and worked lumber since strength is a verr important consideration in structural timber, and it is highly desirable that this class of material be graded on the basis of strength, so that the 
"better" grades will be uniformly stronger than the poorer ones. 'This allows higher fiber stresses and consequently more efficient use, since allowance does not have to be made for the occasional weak piece which slips in under grading rules patterned after lumber grading rules. 'The laboratory has studied and analyzed the effect of defects and physical properties upon the strength of structural material, and has drawn up grading rules for the two principal structural timber species. These rules have been adopted by the associations concerned and are now in everyday use. Tables of allowable fiber stresses under various conditions of service to be used with these rules, have also been drawn up. So far as known, this is the first successful attempt on a commercial scale to grade structural timber on a basis of strength.

Efficient design of any article requiring strength demands not only that sufficient strength be present, but also that this strength be secured at a minimum expenditure of material. To balance the construction by the elimination of surplus material is frequently more difficult than simply to strengthen an admittedly weak part by the addition of more material. Through a series of tests upon white oak barrels, in which the barrels were subjected to various kinds of tests, such as internal pressure tests and drop tests, the laboratory determined the proper relation among stave thickness, head thickness and hoop spacing to yield the best service with the smallest amount of material. New types of barrels, based upon the results of these tests, have been approved by the Interstate Commerce Commission. Just as in the design of barrels, so also with boxes, crates, and other types of shipping containers, one of the most important design problems is to secure a "balanced construction" affording greatest strength at least cost. The proper selection of the species or kind of wood for various uses is also very important.

The laboratory has perfected a box testing drum giving consistent results which indicate the value of any type of construction for the shipment of goods and has developed various standard types of box constructions which have been adopted by the associations of manufacturers and of users of boxes. It has also investigated and tested the relative value of many woods for box making and divided them into four groups on this basis, the woods in each group to be used interchangeably. This work represents the greatest single step forward 


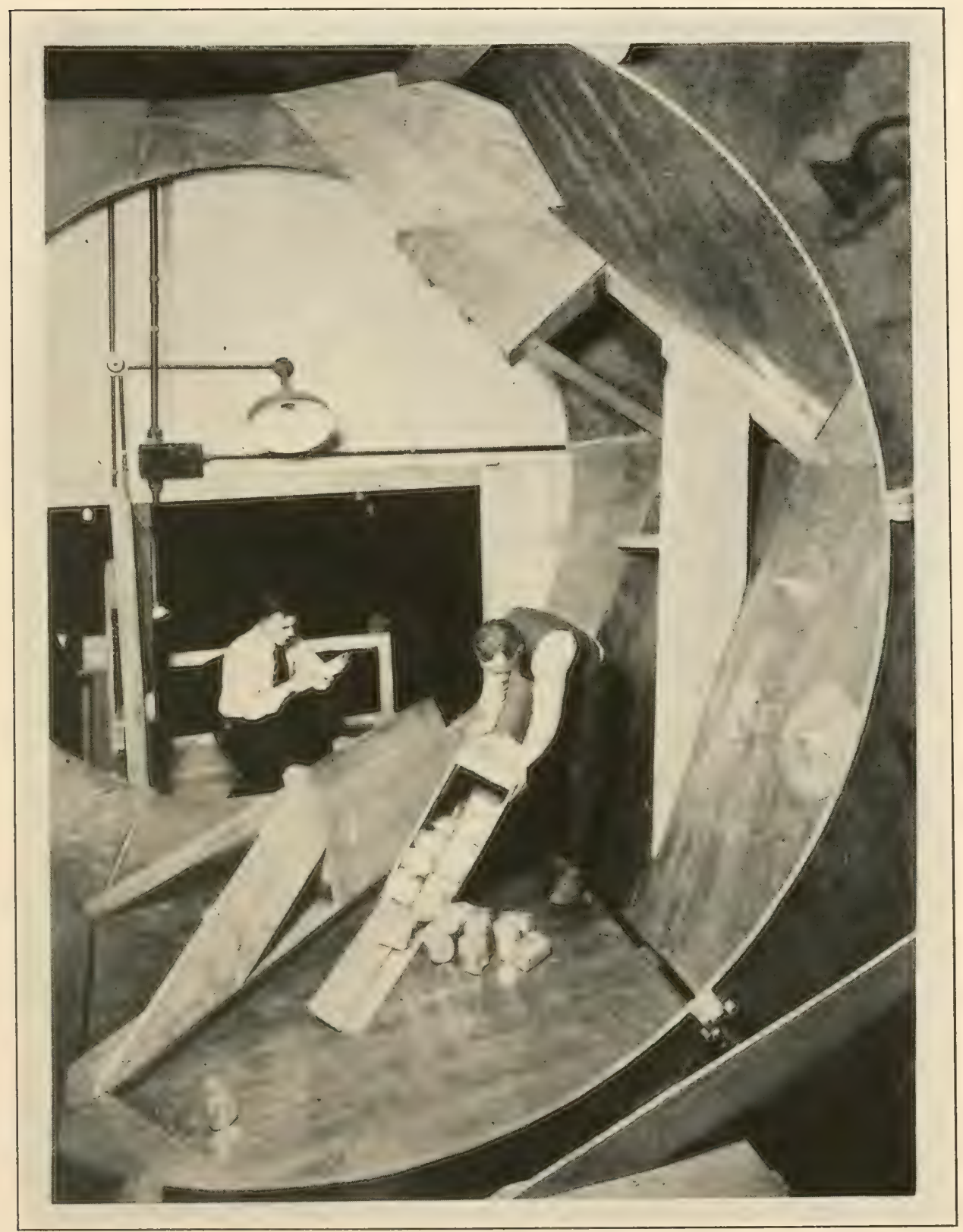

BOX TESTING IN THE BIG TUMBLING DRUM-A LABORATORY DEVICE FOR QUICKLY DETERMINING BOX OR CRATE WEAKNESSES 
in box design and proper selection of box species which has so far been taken.

Typical of various studies is the one made on hickory. A large number of tests on spokes and other vehicle parts showed definitely that "red" hickory was not inferior to "white" hickory in its mechanical properties, and that grading rules discriminating against it on account of color were basically unsound. Tests on larger vehicle parts such as axles, bolsters, and poles brought out the relative merits of hickory and rarious substitute woods which the ever-increasing shortage of hickory has forced into use.

The relative strength of various species of wood when used as telephone or other electric poles has been determined through actual strength tests of a number of poles. simulating as nearly as possible actual conditions in service. Several series of tests have also been made upon cross arms of various sizes and species. to determine the strength and proper design.

For many years, timber cut from southern pine trees which had been "bled" or turpentined was considered inferior on that account and suffered discrimination. Strength tests made upon "hled" and "unbled" wood showed that the turpentining had not in jured the wood. and enabled this material to assume its proper commercial value.

\section{In the Preservative Treatment of Woods}

'The preservation of structural timbers against decay has long been recognized as very desirable, particularly from the economic standpoint, and the treatment of this class of material is growing. There has, however, been considerable confusion concerning the effect of the treatment upon the strength of the material. 'This has naturally tended to retard the progress of the art. The laboratory has conducted a series of tests upon various species of wood, treated and untreated, and has shown just how much each kind of treatment has affected the strength. This led to improvement in processes which were injurious and to greater confidence in the strength of treated timber, besides furnishing data to be used in the design of structures of treated timber.

Wooden piling and other wooden structures placed in salt water. especially in southern waters, suffer severely from the attacks of marine borers of various kinds, and the annual loss from this one cause 
alone is tremendous. Preserration with creosote has been practiced for many years, but not always with success. 'The laboratory hats made extensive studies on the resistance of various tars and creosotes and their fractions to marine borer attack. and has collected numerous service records. 'The problem is by no means solved, however, and many related factors such as temperature and salinity of water, available food supply and other biological aspects of the question need further study and correlation. A great deal of study must also be made upon the rarious constituents of creosote and their relative effectiveness.

'The discoloration of the sapwood, principally of pine, which is commonly known as "sap stain". is considered a defect in most grades of finishing lumber. and causes much loss from degrade. V'arious improrements in chemical dipping to prevent sap stain have been leveloped at the laboratory, and experiments have been made showing that proper kiln drying will obviate the staining.

An objection frequently raised against creosoted wood block parements is that the creosote oozes from them in warm weather, producing a very disagreeable and dangerous surface. After a study of the various factors involved and the making of a number of experimental preservation runs on wood blocks, a method was evolved whereby the observation of certain precautions in the process resulter in reducing to a minimum the oljjectionable "bleeding" common up to that time. In the drawing of specifications adopted by the American ITood Preserver's' Association and the American Society for Municipal Improvements, for the treatment and laying of wood blocks in pavements, the laboratory played a prominent part.

Knowledge of the toxicity and preservative value of different kinds of preservatives. both proprietary and otherwise. is fundamentally necessary. so that the good ones may be developed and the poor eliminated. The laboratory has made tests on and analyzed practically all the important preservatives which have been on the market since its inception.

Fundamental information concerning the relative ease of treatment with preservatives has been obtained for all of the woods ordinarily treated in this country. In important commercial application of this information lies in the grouping of woods for treatment. 


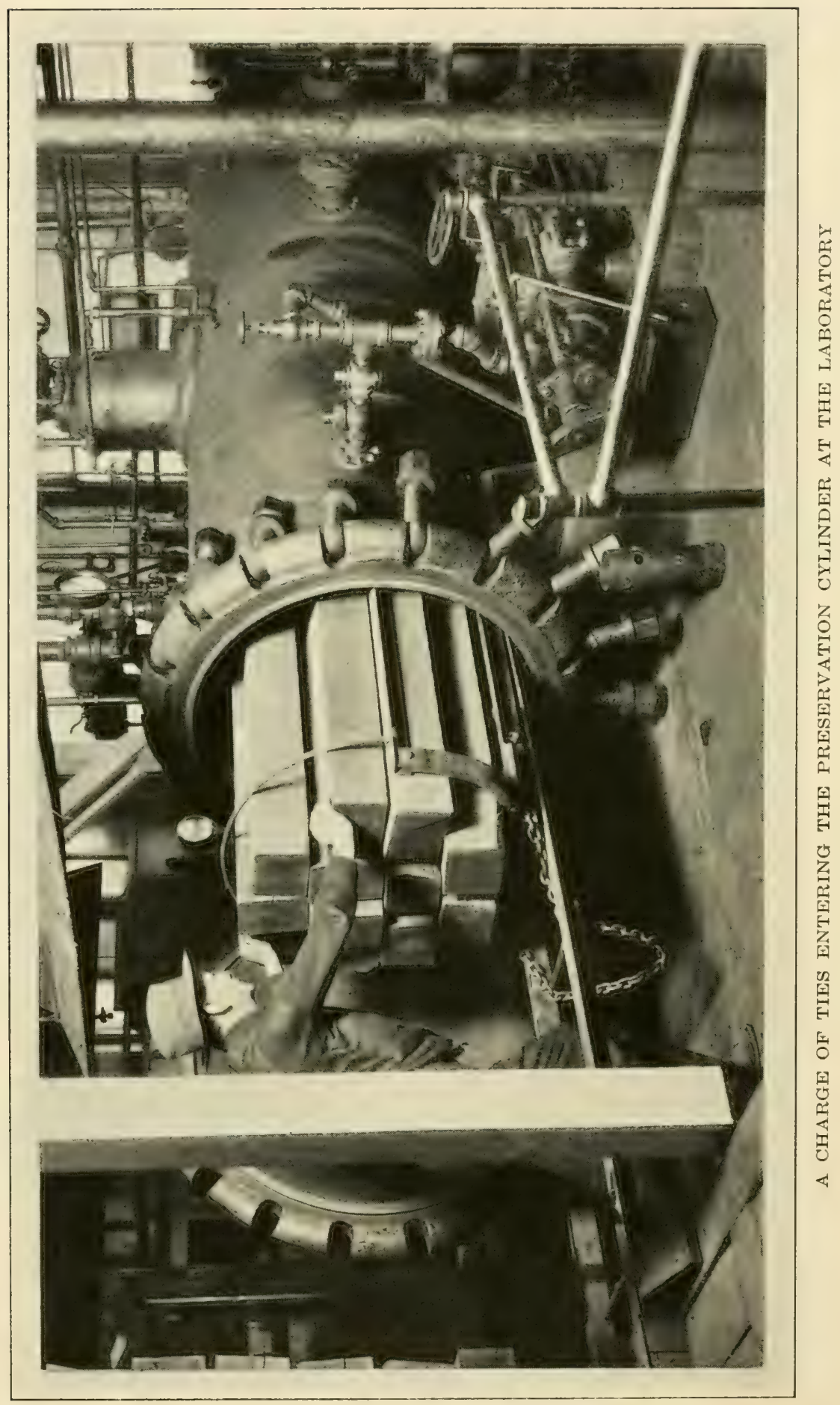


A subject of tremendous importance, upon which comparatively little work has henn done so far is the fireproofing of wood through painting or the injection of chemicals. 'The laboratory has dereloped apparatus for the measurement of the inflammability of either natural or "fireproofed" wood and has studied the relative inflammability of untreated wood of many species and of specimens treated with various kinds of fireproofing agents. The relative value of several methods of fireproofing has been studied and a fireproofing paint developed.

The final test of any wood-preserving process or material lies in the results which it rields in actual service: no laboratory test can simulate the widely rarying conditions encountered in use with sufficient accuracy. Therefore, a large number of experimental tests of treated timber have been placed throughout the country, principally in cooperation with large consumers of timber. There are tests of treated ties, poles, fence posts, mine timbers. wood block parements, and piling timbers, some of which have been in place for about 15 years. Yarious treatments and various species of wood were used in each case, and complete records of treatment and periodical inspection kept. These records form the best arailable measure of the value of various preservatives and preserving processes under ordinary service conditions.

The study and analysis of wood preservatives has been a major project since the inception of the laboratory. Especial attention has been giren to the analysis and grading of coal-tar and water-gas-tar creosote, and a number of refinements have been made in the art. This work has had commercial application not only in the improvement of specifications for preservatives, but also in the modification of the technique of plant operation.

\section{In Kiln Drying and the Physical Properties of Wood}

The artificial seasoning of wood, commonly called "kiln drying", has been practiced by rule-of-thumb methods to a large degree for" many years; and in any erent it was a commercial practice only with comparatively easy drying conditions, since little progress had been made in handling successfully the drying of species and sizes of materials which did not readily respond to the generally unscientific proc- 
esses in rogue. Recognizing that, after all, any failures to succeed with the more difficult conditions imposed by the demands of industry for wider application of kiln drying, were simply attributable to a lack of fundamental knowledge of the physical properties of the wood to be dried, the laboratory from the beginning made kiln drying one of the leading studies. The study centered on the physics of timber and, as a natural auxiliary, a study and consequent development of apparatus to perform the drying operation.

The outstanding features of kiln drying as dereloped in the past ten years at the laboratory are: first. absolute control of moisture and temperature conditions in the entire kiln or any part of it at any stage of the drying; second, an exact knowledge of physical changes taking place in the lumber in the kiln throughout the run; and third, the perfection of means of diagnosing these changes and applying any corrective measures necessary in case adverse conditions derelop.

'The natural result of these ten years of study has been a notable contribution to the knowledge of timber phrsics, the invention and development of sereral types of kilns and auxiliary apparatus that have been quite widely adopted in the fields of kiln drying where ther are especially suited, the extension of kiln drying with its economic advantages to new fields and the elimination of much loss that had been taken mistakenly for granted in kiln drying practice.

Schedules for proper drying with practically no loss from degrade, have been dereloped for many species and sizes of material from dimension oak to smaller sizes of pine. As to the kilns, the water spray and superheated steam types are largely of laboratory development. and they have received the main attention considering the objectives in mind.

Fundamental data on the structure of wood, as revealed under the microscope, serve as foundation for many laboratory studies, and for the identification of wood as to species through examination of the wood itself rather than by a study of the botanical characteristics of the tree. Authentic specimens of most of the trees native to this country have been collected, and microscopic slides made showing radial, tangential, and cross sections. These have been studied and analyzed and a key constructed, by which it is possible to distinguish most commercial species. This ker and the slides are in constant use in the identification of samples of wood submitted by organizations 
and individuals outside of the laboratory, as well as for routine identification within the organization.

\section{In the Use of Wood for Pulp and Paper}

One of the most comprehensive investigations completed by the laboratory is the one on the grinding of wood for mechanical pulp, which was conducted in a full size experimental ground-wood mill especially constructed for the purpose at Wausau, Wisconsin.

This study brought out the fundamental principles underlying the grinding process and the effect of certain variables such as pressure, speed and quality of grinding surface upon the quality and amount of pulp. 'The effect of preliminary steaming of the wood upon the pulp was determined for a number of species, and the suitability for mechanical pulp of a large number of American woods was determined. In fact, experiments were carried out on all species which seemed to have any possibilities whatever; it being the intention to make the study so nearly complete that no further work would have to be done upon grinding for many years to come.

Studies of similar breadth and scope have been under way for many years in the production of chemical pulps from American woods. Two principal objects have been aimed at, viz., to determine the fundamental cooking or pulping conditions underlying each of the three principal chemical processes (sulphite, sulphate and soda), and to determine the suitability of the individual species for the production of pulp by the process or processes to which it is adapted. These studies were not quite completed when war activities made it necessary to abandon them for the time being. They have since, howerer, been finished and the results made available.

Most paper is bought and sold upon specification, and the specification usually has some provision concerning the physical properties. Methods of determining these properties have been very unsatisfactory, however, and knowledge concerning the subject lacking. A special testing room in which the atmospheric conditions can be kept constant, has been constructed and series of tests made to derelop the inter-relationship among the various physical properties and to improve methods of test. 'The effect of atmospheric moisture upon the strength of paper has been determined, and several new methods of test perfected. 
In connection with the investigations into the fundamentals of the chemical pulping processes, attention has been directed to the improvement of the processes in their various details. Typical of the improvements worked out is the impregnation of the chips with cooking liquor before starting the cook. This is applicable to the sulphate and soda processes and produces more uniform cooking and increased yields of pulp, at the same time reducing the cooking period and the steam consumption. The commercial trials of this improvement were successfully completed shortly before the declaration of war.

There are many problems in the specialty fields which could be solved if time and funds were arailable. On some of these the laboratory has worked as occasion arose. In connection with the utilization of waste hemlock bark from pulpwood, a new use for spent tanbark presented itself, and experiments were undertaken to determine its commercial value.

As a direct result of this work, a number of companies began the use of a certain percentage of spent tanbark in the manufacture of roofing felts, in place of cotton rag stock. This produced a new market and exercised a stabilizing effect upon the cotton rag market, which had begun to skyrocket.

\section{In the Derived Products of Wood}

The hardwood distillation industry is one of the older woodutilizing industries, and has gradually developed to its present state largely without the aid of organized research. The laboratory undertook a series of experiments to determine the fundamentals of the process and found that proper control of the temperature in the retorts during distillation produced decided increases in the yield of valuable products without increasing the time required. This improvement has been rapidly adopted by the industry.

Beech, birch, and maple have always been considered the standard woods for distillation, and only a very small percentage of other woods was used. As part of its distillation studies, the laboratory determined the value of a number of other hardwoods such as oaks and chestnut, and demonstrated that the yields from sereral were sufficient to warrant commercial exploitation. Several plants have recently been erected to distill these substitute woods exclusively. 
A number of demonstration experiments have been made in cooperation with the Bureau of Mines to show the value of certain tars and oils, products of both hardwood and softwood distillation, as agents in the flotation process of ore separation. Sereral of these distillation products have proved themselves well adapted for this purpose, and have assumed definite commercial ralue, instead of being merely waste by-products.

Certain perculiar properties of wood turpentine, not possessed by gum turpentine, created a prejudice against it and retarded its sale. The laboratory made a very complete study of wood turpentine, including methods of analysis, methods of refining, chemical composition, and commercial value, and through this study assisted in obtaining proper markets for it.

'To assist in the development of efficient utilization of softwood sawdust and similar waste wood, the laboratory has carried out detailed fundamental efficiency studies on the process for obtaining ethyl alcohol from wood. These studies have determined the best operating conditions and the amounts of alcohol which can be obtained from various species of wood. Special research in the fermentation of the sugars-one step in the process-has resulted in a decided increase in the yields of alcohol commercially produced.

In this same connection, investigations have been carried out on the fermentation procedures for the fermentation of sugars contained in waste sulphite liquors. This waste is produced in rast quantities in sulphite process pulp plants of the country. and the investigations established a means of increasing the yields of ethyl (grain) alcohol obtainable from the waste material.

Basic underlying data on the chemical composition of wood and on the effect of varying chemical composition on the physical and mechanical properties have been entirely lacking; methods for making the chemical analysis have not even been completely dereloped. The laboratory has made a fair start on this work, and has made progress in the refinement of methods of analysis. The analysis of several species of wood has been completed.

\section{Conclusion}

This, in brief, outlines the major fields of work done by the laboratory during the first years of its existence. The formative 


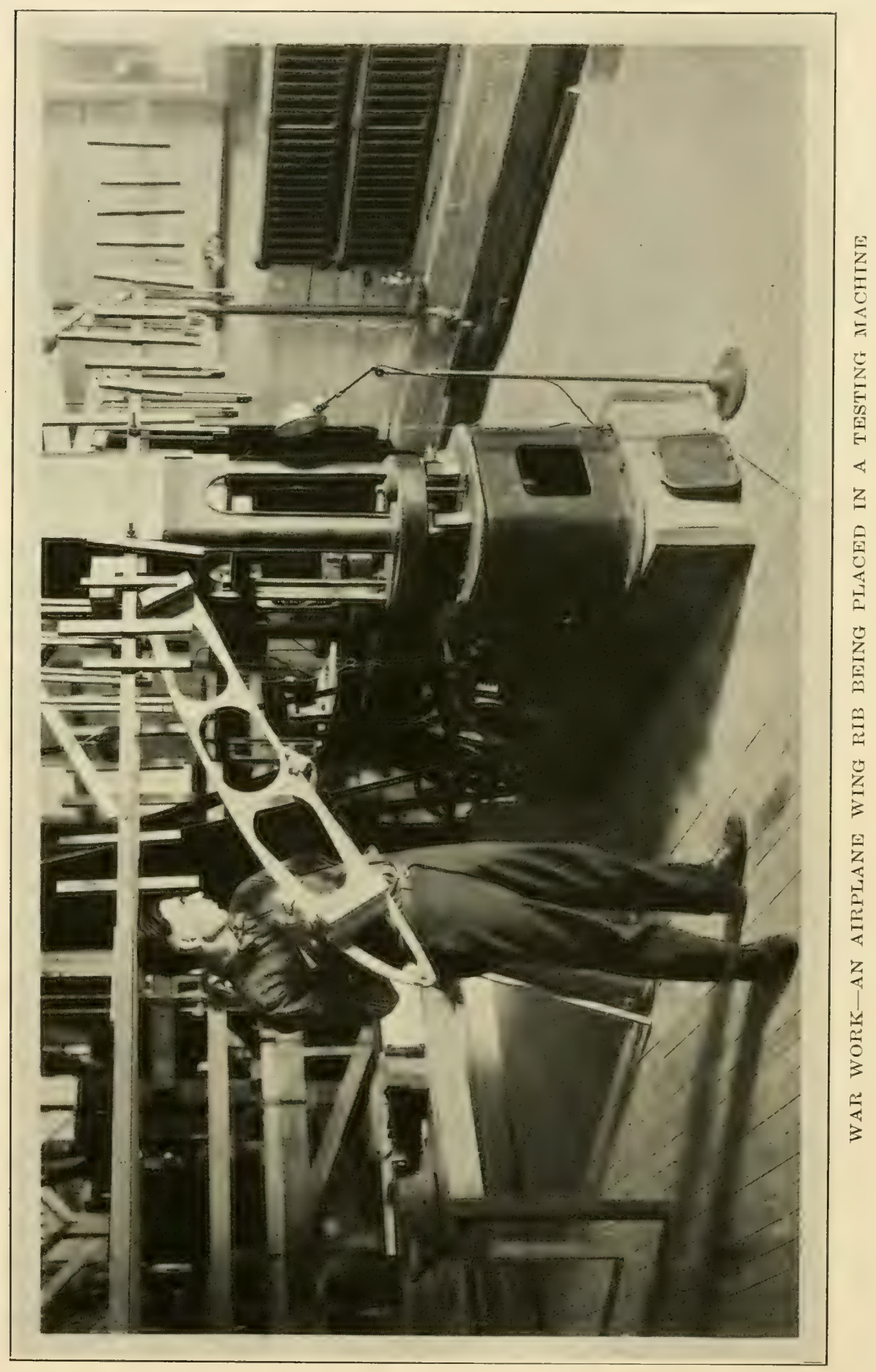


period can definitely be said to have been passed. 'The work in wood products research had been clearly defined and many plainly blazed trails had been opened through this little traveled field by the time the world war assumed for the L'nited States a more critical aspect. Before the war was orer, these trails were widened to broad highways orer which traveled many agencies and interests that sought the help of this institution in solving problems vital to the welfare of nations.

\section{WAR WORK}

The declaration of war on April 6. 1917. found the laboratory with a fund of basic information on wood and wood products. welldeveloped apparatus and equipment for research and a small but well-organized staff numbering among its members men with nationwide reputations in their indiridual lines of research. Better still, the personnel, largely composed of those who had seen the birth of the laboratory or helped in its early growth, was possessed of a sense of partnership in true pioneer work, and of a spirit that stands out as one of the real assets of the institution in the time of stress that marked the opening of the war. It was this spirit that contributed largely to whatever measure of success may have been achieved later, for it kept the force largely intact despite the material gain or increase in personal prestige that awaited in so many other fields, military or civilian. at that time. Without this loyal nucleus the usefulness of the laboratory to many war agencies would have been much limited.

The entire energy of the whole organization was at once deroted to the most efficient use of its knowledge and facilities in the prosecution of the war. A careful surver immediately showed that the lahoratory's help would be needed in the solution of a great many problems conf ronting these departments. A general list of problems was drawn up, and steps taken to get into contact with the proper agencies and to start the various researches which were plainly needed.

This survey of forest products needs in relation to national defense served to bring out with startling clearness the rast importance of wood and other forest products in warfare. Wood in the form of lumber, timber, ties. posts. poles, piling. etc., must be supplied for uses similar to those prerailing during times of peace. such as for buildings (barracks-cantonments), railroads, bridges, telephone and 
telegraph lines, docks, ships, boxes and crates, furniture, fuel, and a multitude of other uses normally associated with modern commerce and industry.

Then there were the multitudinous special war uses of wood in the building of airplanes, trucks, artillery wheels, and escort wagons, as well as for gunstocks, handles of trench tools, mortar boxes, and posts for entanglements, to mention but a few. In the building of trenches, essentially a mining operation, there were required in the last war millions of feet of lumber to mantain these works and make them habitable. For most of these uses experience has found no other material to substitute for wood.

In war time the demand for wood pulp jumps tremendously, largely through the increased demand for paper. For instance, in France, despite the suspension of many journals the number of copies of papers issued daily jumped 100 per cent over peace times. Wood pulp, in the emergency, in the blockaded central European countries assumed vast importance in the manufacture of explosives, as a substitute in surgery for absorbent cotton dressings, in the making of textiles and clothing. As one German editor expressed it fervently, "'To be without wood is almost as bad as being without bread."

The chemical aspects of the wood situation likewise play a tremendously important part in the game of the nations-distillation products, for instance,--methyl alcohol and its important part in the making of medicines and disinfectants, in the manufacture of dyes and other products; acetic acid; the turpentines and resins. These need merely be named to conjure up the impossibility of carrying on important functions connected with modern warfare lacking ample supplies of these products derived from wood.

\section{Personnel and Financial Situation}

In addition to establishing contact with the various war agencies and getting under way the most urgent researches, plans were immediately undertaken for the expansion of the organization to meet the greatly increased demands which it was erident would be made upon it, and for providing the necessary funds and the additional laboratory space.

The demand for the facilities of the laboratory at once raised a critical financial situation that needed solution before expansion could 
be authorized. While the very limited appropriation for the regular staff could be devoted to war time work, the amount was fixed. Recognition of the situation by the Forest Service resulted in transferring small amounts of money created by adjustment of work in other fields and also in the sending of experienced personnel to assist in the enlarged program. Despite these adjustments, but little progress could have been made without the allotment of funds from the various cooperating bureaus in the Army and Navy departments. From these sources came the bulk of the funds used for carring on the important war program. Additional space, as needed, was made available through the patriotic cooperation of the University of Wisconsin, a number of whose buildings, in whole or part, were racated and turned over to the laboratory during the period of the war.

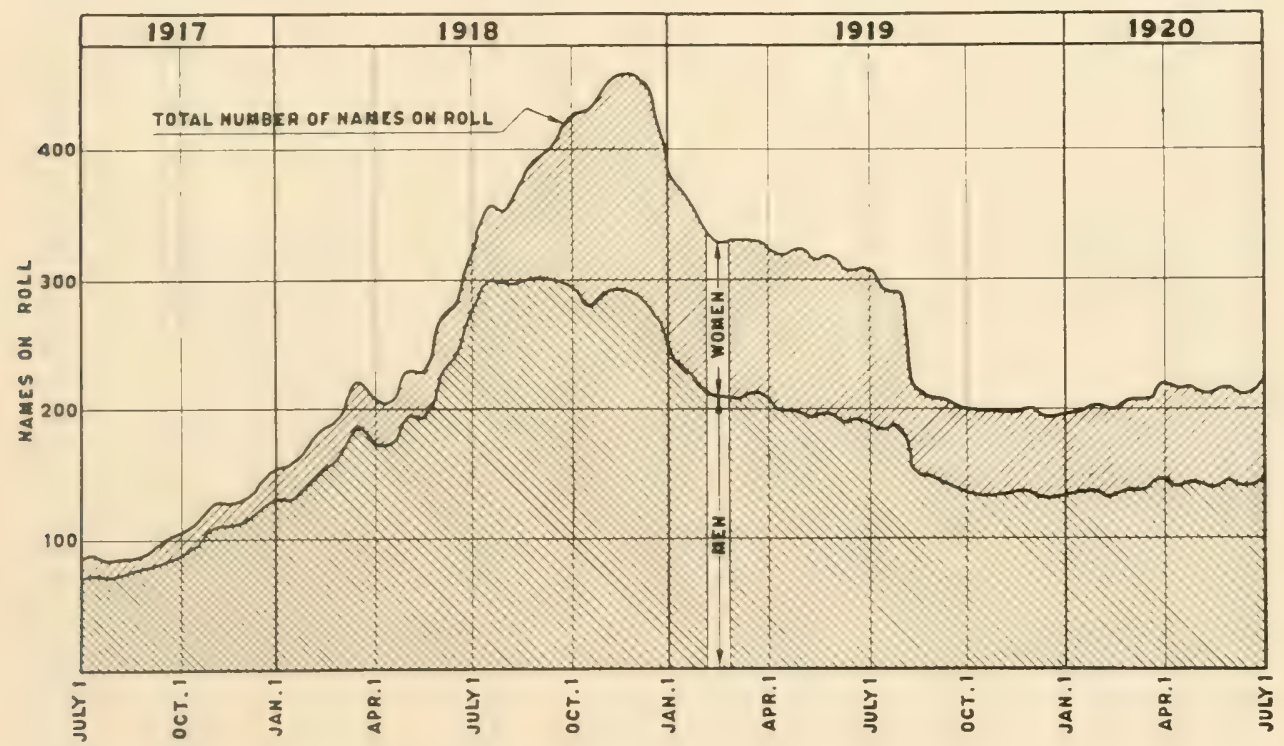

PERSONNEL DEVELOPAIENTS AT THE JABORATORT-JULT 1917 TO JULY 1920

Of the many difficulties encountered in carrying on the necessary work, the matter of personnel was ever present. 'The dearth of properly trained men who could be secured at the comparatively low salaries which the laboratory was able to pay was always most acute, and was largely responsible for many irksome delays in expanding the organization. This expansion went forward, however, at a reasonable 
rate, and on armistice day the entire force numbered 458 persons. After that time, the personnel was gradually reduced, and much of the emergency work dropped. However, certain of the projects, especially those of importance in peace-time developments, have been continued, support for them being largely furnished by the cooperating bureaus. The war expansion and the relative personnel situation today and in 1917, prior to the sudden growth of the laboratory, can be seen at a glance in the diagram on page 39.

\section{Kiln Drying of Aircraft Woods}

In presenting the accomplishments of the laboratory during the war period, it will be necessary to include a certain amount of background, so that each research may be properly oriented and fitted into the general plan of national defense. The very essence of this work was the necessity for the development of unprecedented supplies of spruce for aircraft production and research. 'The demands of the allied nations for aircraft materials in the years preceding the entry of the United States into the war had practically cleaned up the available supply of air-dry spruce in the country and in addition, the production of green spruce was entirely inadequate; though eren had it been sufficient, the delay incident to air drying would have been prohibitive. The only alternative was kiln drying. Utilizing the available knowledge possessed by the laboratory in this field, the proper authorities were convinced of the practicability of kiln drying material green from the saw to a condition equal to or better than air-dried stock. The preparation of kiln-drying specifications covering the principal aircraft woods followed and they were almost immediately approved by the Signal Corps and became the standard for both Army and Nary.

'Tnder these specifications it was possible to dry three-inch green spruce planks in 21 days, ordinary air seasoning taking from six months to a year, depending upon climatic conditions. Batteries of suitable kilns were erected by the Army and Navy for the drying of aircraft woods, the largest of these being at Vaucouver Barracks, Washington. In the erection and operation of this large drying plant considerable technical advice and assistance was rendered by the laboratory. Several aircraft manufacturers also installed similar kilns 
or kilns based on laboratory ideas with modifications to suit particular conditions in their product.

The drying schedules embodied in this specification were considered perfectly practical and safe from the standpoint of the strength of the wood; however, it seemed desirable, especially in the case of various woods which were being considered as substitutes for spruce and for mahogany and walnut (for propellers), to secure additional data on the effect of various drying schedules, inchding those specified, upon the mechanical properties of the wood. These data were intended to determine the limits, as to drying schedules, which could not be exceeded with safety, it being adrantageous, of course, to dry the stock as rapidly as permissible. Therefore, a comprehensire program of drying and testing was initiated. Thousands of strength tests were made upon carefully matched specimens, green, air-dried, and kiln-dried, and the effect of the drying upon the strength determined by analysis of the data.

\section{Work on Design of Aircraft Parts}

There was inmediate demant for accurate strength figures for woods used in aircraft design, and it was possible to supply much of this information from data on hand. A study of the data arailable on most American species resulted in the approval in specifications of suitable substitute species for woods commonly used in airplane manufacture. The list of approved substitute woods issued by the Bureau of Aircraft Production was hased upon the results of these studies.

Designs and specifications for airplane wing beams presented many perplexing problems: to secure reasonable quantities of perfect beams, each machined out of a single piece of wood, was quite impossible. It hecame necessary, therefore, to devise ways and means for the production of satisfactory beams from defective material. Two general lines of attack were followed, namely. (1) a study of defects and (2) the development of built-up beams.

Much attention had been given to defects and their effect on strength prior to the war. but further study of earlier results coupled with some additional tests gave complete data on the relation of pitch pockets, knots, cross grain and spiral grain to the strength of a given 
piece. The result was the issuance of specifications which described the kind, size and location of defects permissible. This specification immediately made available many beams which had already been rejected, and increased greatly the yield of acceptable beams.

Active investigation into the relative merits of various types of built-up airplane wing beams was undertaken early in the spring of 1918 at the urgent request of the Bureau of Aircraft Production. The need for such investigations had been apparent for a long time, and fairly thorough knowledge of the history of the use of the various types had been secured; but lack of ability to organize for this work in addition to that already under way had prevented progress in the study. Clearing of the way for this work resulted in the evolution of a satisfactory beam as the result of an intensive test and study of 300 beams comprising that number of individual variations of ten main types of construction. Subsequent tests developed the best types of splices for flanges and webs, and detailed data was secured concerning the behavior of individual woods with different types of glue used in making built-up beams.

'The possibility of improvements in design, especially in the larger' beams, became evident; further, the matter of "form factors" to be applied to beams of various forms in making strength calculations assumed importance because cross section has an important bearing on specific strength. Consequently, tests on built-up beams have been continued since the armistice and sereral noteworthy improvements brought out.

As the engineers in charge became more familiar with aircraft design and construction, they saw more and more details which needed improvement. Among those aircraft parts which seemed to suffer most from poor design were the wing ribs, not only of the training planes. but also of the fighters. Almost the first test made showed that improvements were possible, and a group of men was given the task of designing, building and testing wing ribs. A standard type for small and medium ribs was erolved and ribs of this type were dereloped for a number of Army and Nary planes. So far as known, the new type was an improvement over all existing types. Later several very efficient truss types were developed for larger planes.

Interplane struts, both solid and hollow, though designed on the basis of formulae which had been checked experimentally, were in- 
spected and selected in a manner which did not seem to insure acceptance of all suitable struts and the rejection of all unsuitable ones. Further, there arose numerous questions concerning the actual strength of certain struts and fittings. A rather extensive series of strut tests was therefore undertaken to answer these questions and rarious others which arose from time to time concerning special types of struts. These tests showed definitely that methods of inspection could be improved materially and that certain special types of strut were not satisfactory. A non-injurious method of test or inspection was devised, and later adopted by the Army, whereby the actual maximum load which each strut can bear is determined. Several noteworthy types of large built-up struts were dereloped for the big flying boats being designed by the Nary.

The improvements in design resulting from the experimental development of beams, ribs and struts made erident the desirability of similar work on other air craft parts. 'Tests were undertaken as opportunity offered, on rarious special details which were giving trouble, and in several cases the development of new principles of construction was carried out. In most instances these centered about the use of plywood. Shortly after our entrance into the war. a very elaborate investigation into the mechanical properties of plywood had been initiated. since there was no information available upon this suljject and its importance in connection with aircraft design was evident. As this investigation proceeded, the possibilities in the structural use of this material became greater and greater, and the new knowledge was applied as quickly as possible. Mention has already been made of the new type of wing rib, a large part of the success of which depends upon the efficient use of plywood webs. 7Iuch of the progress made in wing beam design likewise was due to the application of the new data to the design of these important parts.

Sereral large elevator spars were designed for Nary flying boats. and in the progress of the test an entirely new type of construction was perfected. The use of spirally or diagonally wound veneer over the core provided very high resistance to torsional stresses with extremely low weight. The net result was a very strong and stiff spar with the minimum weight.

A new engine bearer was designed for the De Haviland plane. 'This bearer is of plywood about an inch thick, cut out of the solid sheet 


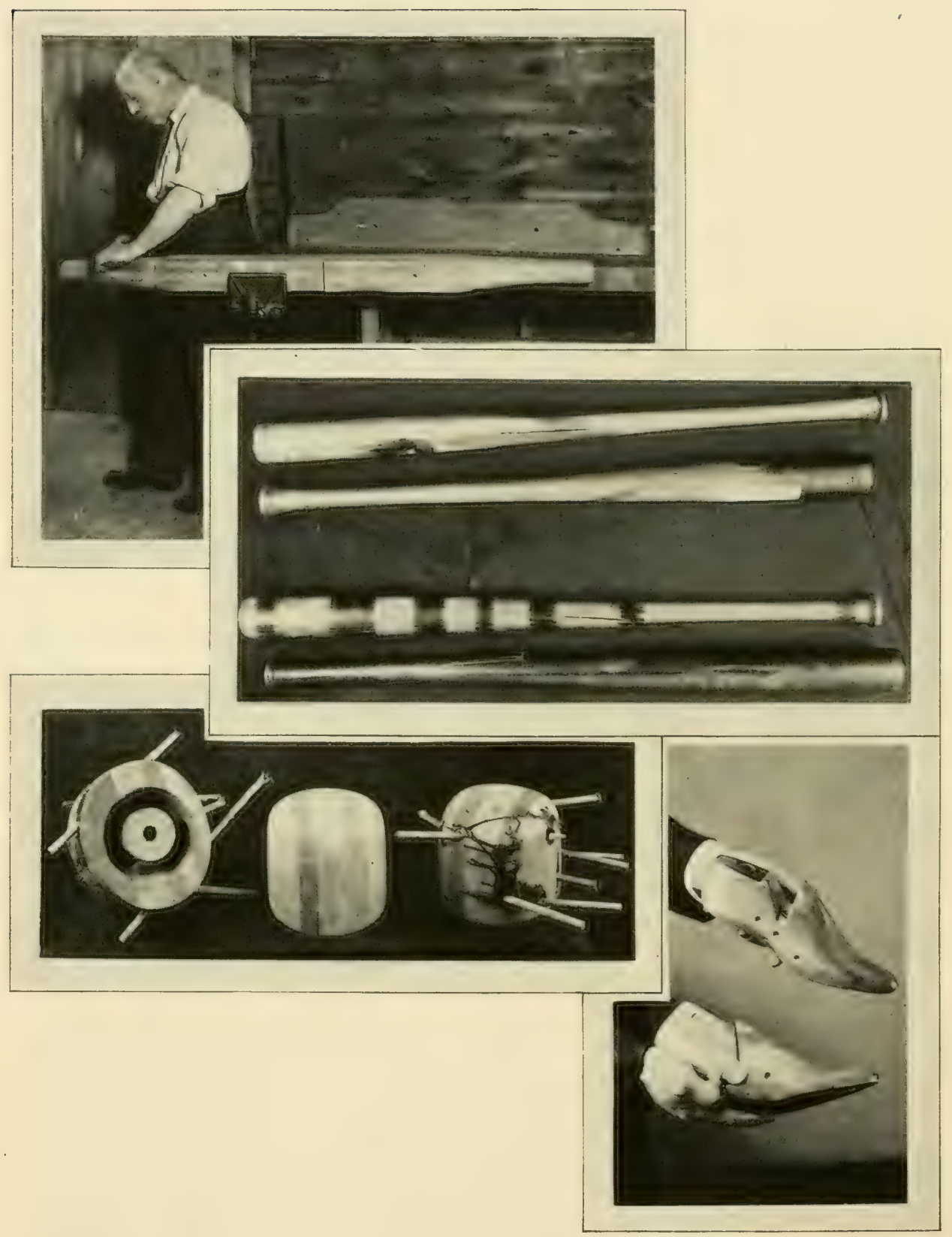

LAMINATED CONSTRUCTION AS APPLIED TO WOODEN ARTICLES OF COMMERCE Wagon Bolster Hat Blocks

Baseball Bats

Shoe Lasts 
and lightened as much as possible through the use of lightening holes. The proper selection of species and thicknesses of piles resulted in an appreciable increase of strength without increase in weight. Similar parts were designed for several Nary planes.

Much attention was deroted to the use of thin plywood as a wing covering and a number of tests were made in the hope of developing a satisfactory linen substitute. Several types of construction were tried out, and interesting preliminary results secured. No corering or type of construction was perfected. howerer. which was superior to the standard wood and linen type.

\section{Development of Watcr-resistant Glues}

Closely associated with most of the aircraft problems upon which the laboratory worked was the all-important one of glues and gluing. A great deal of reliance is placed upon glue in the construction of the ordinary plane. since many of the structural parts are glued together, and it is essential that only the best glues and best gluing technique be employed. 'The first request for help came from the Signal Corps in the spring of $191 \%$, asking for assistance in hide glue inspection. No standard. usable system of grading and inspection was available, but one was quickly developed at the laboratory by an inspector assigned to the work. and all hide glue used by the Army dir Service as well as much of that used hy the Nary Air Service was inspected and certified by him and his assistants.

Attention was then directed to the great desirability of using water-resistant glue in aircraft construction, not alone on account of exposure to the weather when in service, but also because of the serere conditions during shipment and storage. It had been known for many years that so-called "water-proof" glues could be made from blood albumin and from casein, and rarious secret formulas had been dereloped and were in use to a certain extent. In fact, it is well established that the enemy was using casein glue in his aircraft before our entrance into the war. In this country there were several small manufacturers of "waterproof" plywood glued with blood albumin. However, there was not arailable for general use an appreciable amount of a suitable water-resistant glue, for either plywood or joint work. Therefore, the perfection of several types of water-resistant glues was immedi- 


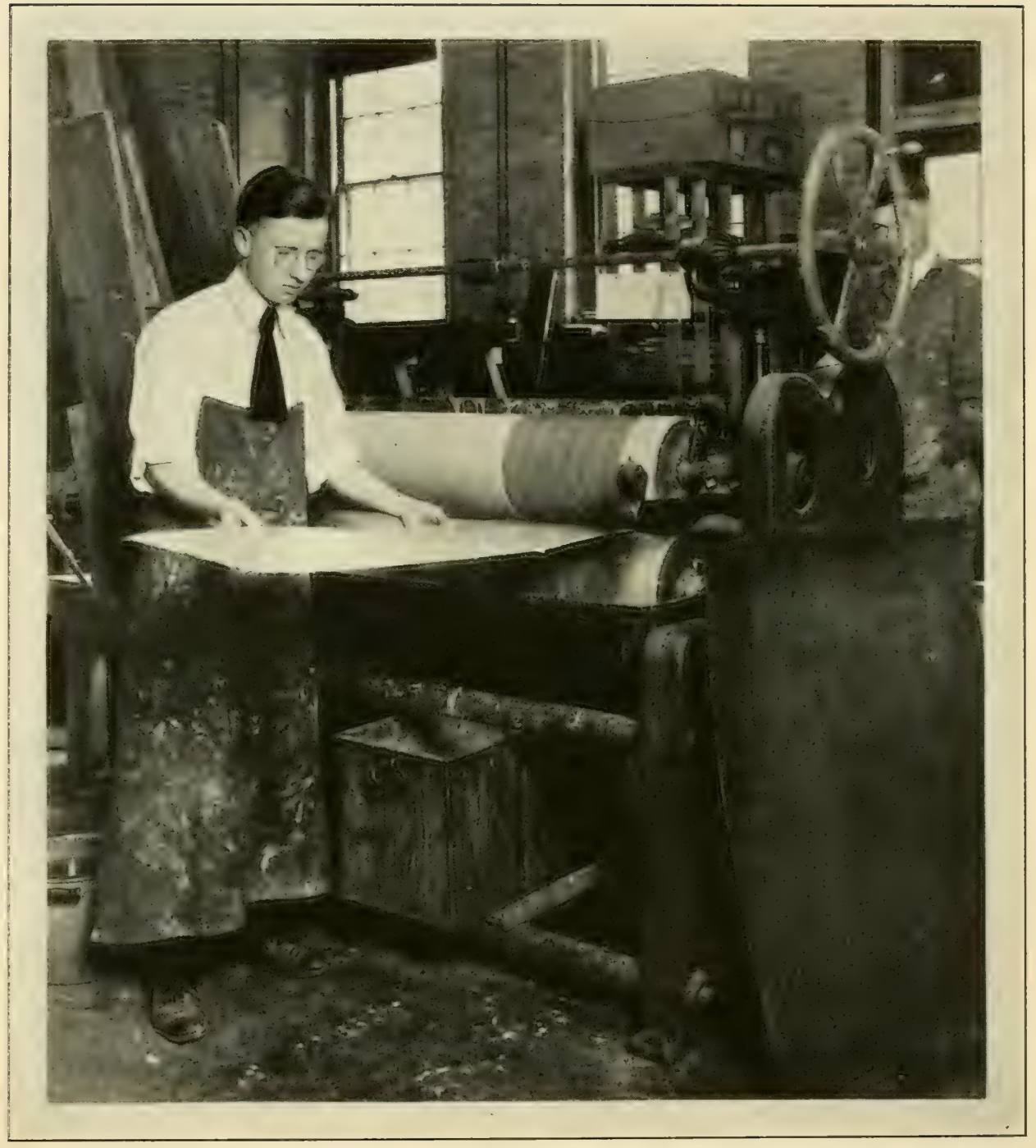

GLUE SPREADING MACHINE-A STEP IN THE MAKING OF PLYWOOD 
ately undertaken. A special staff of chemists and assistants was gathered together, and the necessary equipment installed. This virtually marks the laboratory's entrance into glue research.

Within a reasonable time, high class glues of both types, blood albumin and casein, had been worked out and made available to the Bureau of Aircraft Production. Regular inspection and test of samples of plywood glued at various plants had been established early in the study and was maintained as an aid to the manufacturers in making a satisfactory product. Assistance was rendered them, also, by trips of inspection and study at the individual plants. In addition to the glues already mentioned, a special kind of blood albumin glue tissue was invented. This is particularly adapted to the gluing of very thin plywood, such as that used in the experiments on plywood wing corering. In connection with the glue work, special studies of the supplies and quality of the raw materials entering into their manufacture were undertaken. Through these, adequate quantities of suitable material became assured.

\section{Propeller Work}

The effect of moisture upon the properties of wood was well known, and it was generally accepted that the planes and their parts should be manufactured at the moisture content which ther would assume in serrice. There were already in existence certain data showing the relation between atmospheric humidity and the moisture in wood, but these were not considered sufficient in riew of the importance of the matter. Therefore, several series of accelerated tests were made, the results pernitting the determining in advance of moisture content that will be reached by any species under given atmospheric conditions.

Closely correlated with this study was an entirely dissimilar one, planned to prevent change in the moisture content of propellers especially during storage under humidity conditions different from those of manufacture or use. 'This investigation concerned itself principally with the rarious kinds of wood finishes and treatments with substances known to be water-resistant. Tests on many commercial paints and varnishes showed that none of these were sufficiently resistant to the passage of moisture through them, and there resulted 
a search for a new and satisfactory coating. Thus was brought about the invention and perfection of the aluminum leaf coating, which is practically impervious to moisture so long as it remains intact.

The change in the moisture content of propellers due to atmospheric conditions, with the consequent warping, twisting, and unbalancing of the blades was only one of many troubles experienced in the manufacture and use of aircraft propellers. The results were, however, much the same. There are many variables entering into the manufacture of propellers, such as differences in weight, shrinkage and moisture among the various laminations, and to separate all of these variables and their effects upon the finished propeller required a very elaborate and costly series of tests on full sized propellers of various species. The species entering into this study were: Central American, African and Philippine mahoganies, white oak, red oak, hard maple, yellow birch, yellow poplar and red gum. A complete propeller manufacturing shop and a number of storage rooms were erected, all provided with automatic temperature and humidity control. Lumber of the different species was kiln dried at the laboratory, and the task of making up several hundred propellers, each in accordance with a definite plan, was got under way. 'These propellers were subjected to various atmospheric conditions ranging from very moist to very dry, and the changes in them carefully measured at stated intervals. This project was not finished during the war, but is now nearing completion. The results are already quite evident, and shortly the desired specifications for manufacturing limits and control will be drawn up in correct and final form.

Many small but important problems in connection with the aircraft program were solved, and much miscellaneous help given, principally through numerous field trips by the technical staff. Permanent record of this service, and of the results of the major studies as well, is found largely in the specifications of the army and navy aircraft bureaus.

\section{Kiln Drying of Heavy Woods}

The sudden increase in the demand for vehicle stock brought about by the need for tremendous quantities of army escort wagons, automobile trucks, and artillery wheels almost immediately exhausted 
the comparatively small supply of dry stock arailable, and left the alternatives of either using green stock or resorting to artificial drying. The former was of course out of the question and many were convinced that the latter also was not feasible. The shortage of northern-grown oak complicated the matter still more since the southern oaks are admittedly much more difficult to dry, and the seasoning losses, even with the most careful air drying, are very large. 'The problem here was to get the wood dry. even if considerable degrade occurred, the derelopment of the last ounce of strength being out of the question and not essential. In this it differed, of course, from the aircraft wood-drying problem.

The laboratory's experience in the experimental drying of rehicle stock and in the design and operation of kilns indicated clearly that successful drying of this class of stock would require very careful control of kiln conditions--an accuracy of control which could not be secured in kilns of the common rentilated types, even with welltrained and skilled operators. The only type of kiln which, in the laboratory's experience up to that time, was susceptible of sufficiently close control was the water-spray type, and therefore this type was recommended for this purpose, and suitable drying schedules were prepared.

'I'his heary drring divided itself naturally into two groups: the army wagons for the (Quartermaster corps, and the artillery wheels for the Ordnance Department. Assistance was given at both govermment-owned plants and arsenals and at contract plants in the design and erection and the eventual operation of numerous kilns handling heary stock, a corps of experts being maintained in the field for that purpose. One man was stationed at the Rock Island Arsenal almost continuously for seren months, while the kilns were being erected and the operator's trained. The knowledge and experience of the laboratory staff and the help which they were able to render made possible, since it enabled the dry material to be secured promptly, the carrying on of the various programs dependent upon heary hardwood stock.

An important problem involving wheel stock was the steambending of the felloes. There was but little standardization of practice in the industry. and the losses which were occurring at many of the plants were rery large. A field study of this problem was under- 


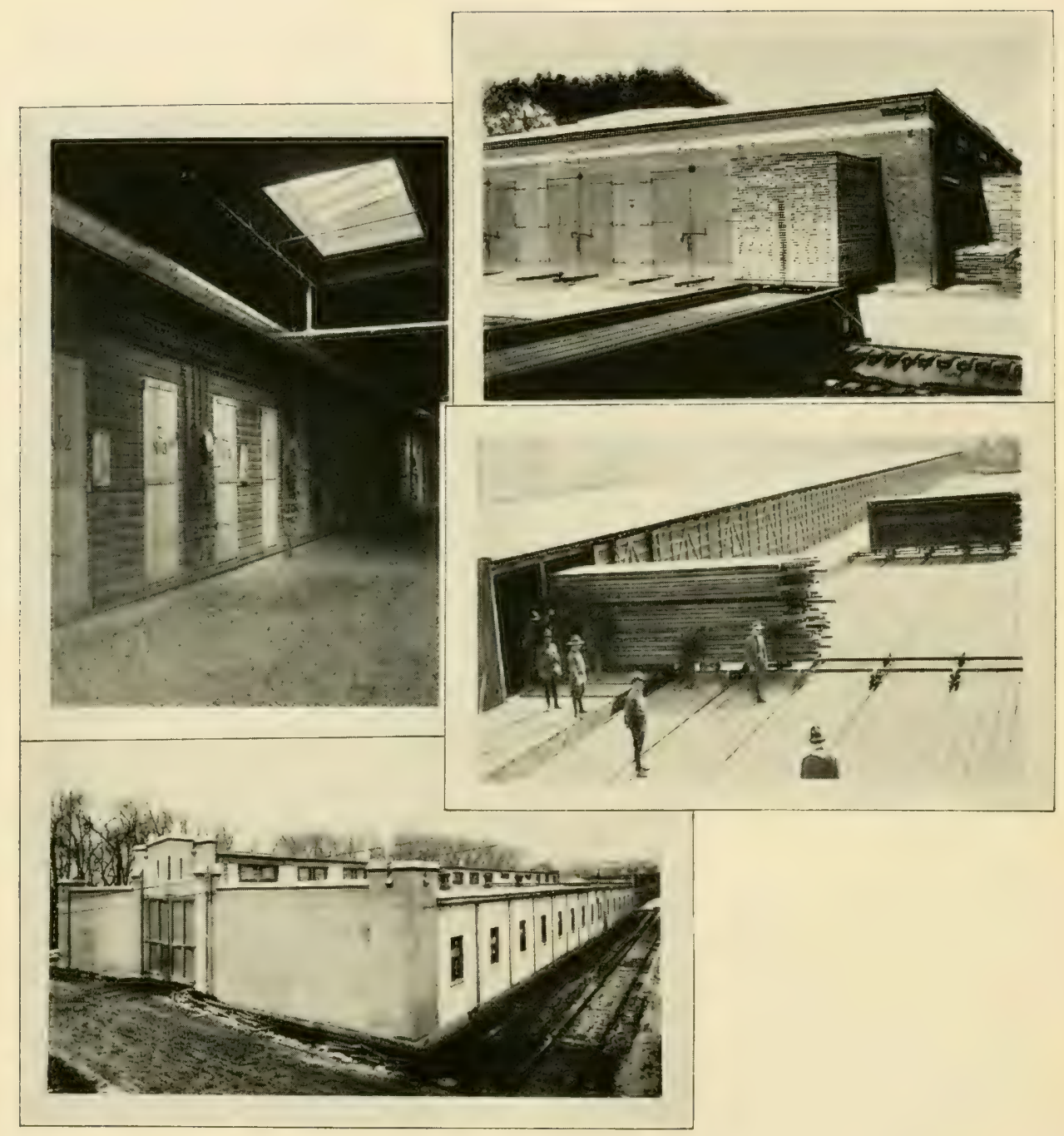

SOME WAR TIME INSTALLATIONS OF TYPES OF DRY KILNS DEVELOPED AT THE IAABORATORY

Contract Plant, Quartermaster's Corps Rock Island Arsenal, Rock Island, Ill.
Naval Aircraft Factory, Philadelphia, Pa.

Spruce Production Division, Vancouver, Wash. 
taken and certain principles determined, the adoption of which cut down the losses very materially. It was evident, however, that further investigation would serve to improve the art still more, and plans were made for an extensive project. A steam-bending machine and steaming retort were installed and preliminary tests had been made when the armistice was signed. Further work has been temporarily abandoned because of the lack of funds.

An interesting phase of the drying situation was that connected with the conditioning of walnut gunstock blanks. The quantity of blanks needed was beyond belief, and naturally, long before the entry of the United States into the war, air-dry supplies of walnut had heen absorbed by rifle manufacturers filling contracts for the allies. The first attempts to kiln dry green walnut when the arailable air-dry material disappeared, resulted disastrously-one instance being recorded when the opening of the kilns at one plant at the end of a run disclosed 60,000 totally ruined blanks with a loss of $\$ 72,000$ in material costs. One firm with an order for two million rifles for Russian use called on the laboratory in this crisis and the application of the drying principles already perfected, supplemented with needed variations indicated after a study of the problems of this specific material, reduced losses to less than two per cent. When the United States itself entered the market for greater quantities of rifle blanks than ever, facilities existed for filling orders without loss and with but little delay.

Additional assistance was rendered in various ways, especially in the preparation of specifications and in the selection of substitute species for those difficult to secure in sufficient quantity. The fund of data on the properties of wood accumulated since the laboratory's inception. coupled with the experience of the staff, proved of very great value in this work.

\section{War Time Bow Work}

The first intimation that there was going to be trouble in connection with the boxing and crating of goods for overseas came when the Ordnance Department sent out requests for bids on boxes, using its standard specifications which called for high grade white pine. No bids came back. The help of the laboratory was sought. and, on the 
basis of its previous experience in box testing, a specification was prepared which allowed the use of many different kinds of wood, the thickness of the boards or shooks rarying according to the species. 'This solved the immediate difficulty and showed the way for much additional work. This was at first largely confined to the Ordnance Department and consisted, for the most part. in the re-design of containers for various specific articles, such as rifles, shells, hand grenades, machine guns, saddles and harness and other equipment covering a wide range. It was possible, in practically all cases, to make a material reduction in the size of the container and also in its first cost without reducing its efficiency. Thus, in the case of the Browning automatic machine rifles, the re-design of the package carring two of the rifles netted a saring of 33 per cent both in cargo space and in material. The significance of the saring in cargo space becomes evident when it is realized that it was valued at $\$ 6.00$ per cubic foot, and was not to be had in sufficient quantity at any price.

Assistance in boxing and crating was rendered to a number of the army branches from time to time, and when the general staff took over many of the functions formerly exercised by these various branches, definite cooperation was arranged with the Office of Industrial Research of the Division of Purchase, Storage and Traffic, which acted as a clearing house and systematized the work to a great extent. When the shortage of cargo space became acute, and baling of many goods was adopted to cut the space required to the minimum, many tests were made upon various types of water-resistant papers to determine their suitability for this purpose. Miscellaneous investigations were made, also, upon various patent boxes and upon different types of straps and seals. Courses of instruction in boxing and crating were given to officers and enlisted men, as well as to civilian employes of various branches of the War Department, and these branches have reported that the courses were of exceptional ralue in building up efficient inspection forces.

\section{Laboratory Participation in Wooden Shipbuilding}

The huge wooden ship program planned by the Emergener Fleet Corporation encountered many technical difficulties, a number of which were new or unusual, and the laboratory's assistance was requested in the solution of a number of them. 
The laboratory's experience in the grading of structural timbers and in the utilization of many of the woods used in shipbuilding was called upon in the drafting of new grading rules for ship timbers adopted by the Emergency Fleet Corporation and in the revision of the rules of construction laid down by the American Bureau of Shipping. Assistance was also rendered in the inspection of timber under the rules of the Emergency Fleet Corporation and for the same organization specifications for creosote and its application were prepared. These specifications permitted the use of all suitable creosotes and made the corporation independent of various expensire proprietary preservatives originally specified.

A shortage of treenail stock and of properly seasoned treenails seemed imminent in the spring of 1918, and the laboratory was called upon to find new kinds of wood and to specify means of artificially seasoning the treenails. This problem was of first importance since. for a time, the supply of treenails actually determined the rate of ship construction at a number of yards. Certain promising species were selected for experiment. and driving tests made to determine their suitability. Live oak and osage orange were selected as comparing farorably with black locust. and specifications were adopted allowing the use of these woods and providing for a better system of inspection. Experimental work upon the kiln drying of these species was pushed by the laboratory and the Fleet Corporation made extensive preparations for the kiln drying of live oak treenails, which were abandoned on the signing of the armistice.

\section{Cooperation With the Railroad Administration}

The shortage of coal-tar creosote interfered seriously with the wood preservation industry, particularly the railroad branch. An analysis of existing records of the service rendered by treated ties throughout the country was made in connection with a study of rainfall, and it was possible thereby to recommend the use of zinc chloride in a number of localities in place of creosote. This formed the basis of the allocation of creosote to the railroads by the Railroad Administration. Specifications for a creosote to be used in the joints in car construction were also submitted. 
The Railroad Administration experienced endless trouble in the construction of wooden cars, largely due to seasoning difficulties caused by the shortage of dry car stock. An extensive field study was made and the exact causes of the trouble determined. A report outlining the proper remedies was prepared and submitted to the Railroad Administration. In various other ways the laboratory worked with the Railroad Administration to solve miscellaneous problems. The results of much of this work appear in the form of specifications issued by the Administration.

\section{Furthering the Chemical Warfare Campaign}

The chemical warfare work for the army was first got under way by the Bureau of Mines and later taken orer by the Chemical Warfare Service when this Service was organized. Specific problems were assigned to various laboratories throughout the country and several having to do with forest products were taken orer by the Forest Products Laboratory.

One of the most urgent needs was for a highly absorbent charcoal for use in gas masks for protection against chlorine. Ordinary charcoals were soon found useless for this purpose and experiments were started to evolve a suitable coal. This resulted in the preparation of a beech-wood charcoal which met the requirements. A similar material had been developed at the same time by the chemists of a large commercial carbon-producing firm. The manufacture of this charcoal was immediately undertaken at a distillation plant under the supervision of a laboratory chemist, only seven days being required to make the needed alterations in the plant. Later on it became desirable, due to a shortage of raw material to find a substitute for the very dense charcoal made from cocoanut shells. This charcoal was capable of absorbing a number of gases against which the beech-wood charcoal offered but slight protection. A method of actirating charcoal, similar to a secret process used by the Bureau of Mines, was first developed, so that activating and absorption tests could be made at the laboratory, following which a series of artificially dense charcoals, made from the hydrolized wood sawdust which is a waste product in the manufacture of ethyl alcohol from wood, were developed. The hest of this series were almost perfect substitutes for cocoanut shell 
charcoal, and the process was worked out by laboratory chemists on a semi-commercial scale at the Cleveland chemical laboratory of the Chemical Warfare Service. The commercial production was just about to be undertaken at the termination of hostilities.

A number of other problems connected with defensive and offensire chemical warfare were worked upon and definite conclusions reached. Changing conditions, however, frequently made the results of no value almost before they were secured. Among these problems may be mentioned tear gases, gask mask filters, carbon monoxide absorbent, solvent for arsene gas, and the recorery of isoprene and toluol from turpentine.

It seemed, at first sight, that our entrance into the war would not throw a very great burden upon the wood distillation industry since the British munitions manufacturers were the only ones using acetate of lime in making smokeless powder and it was not anticipated that American manufacturers would produce this particular type of powder. It soon developed, however, that the aircraft program would, demand twice the current production of acetate for the preparation of the cellulose acetate "dope" used to shrink the wing fabric.

The Signal Corps finally decided to construct several new distillation plants, after the field had been carefully gone over and the merits of rarious expedients determined. 'The laboratory acted in a consulting capacity in all of this work and also assisted plants already in operation to secure greater yields through the use of a temperature control method worked out by the laboratory before the war.

Later, when the demand for acetic acid became so acute that the price of production no longer was a controlling factor, a method of increasing the rields of acetic acid by fusion of the wood with caustic soda was perfected. 'This method produced three and one-half times as much acetic acid per unit weight of wood as straight distillation.

\section{Wood C'cllulose for Explosives}

Among the many fancied and real shortages of raw material, those having to do with munitions were perhaps the most spectacular, because their immediate significance was most easily appreciated by the lay mind. Among these munition shortages none seemed to come so unexpectedly or develop so rapidly as that of cotton linters. the 


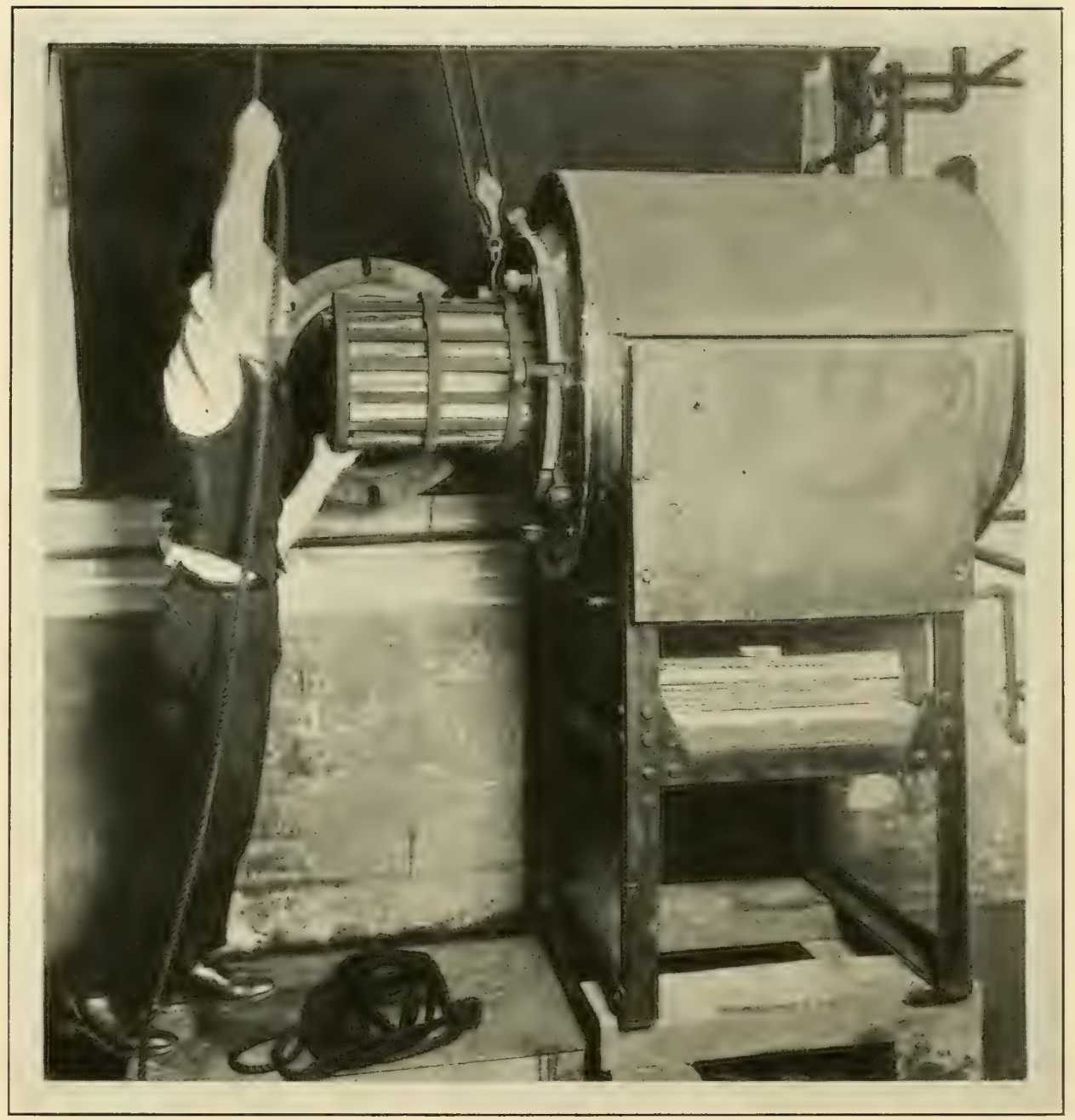

WOOD DISTILLATION RETORT-A CHARGE BEING PUT INTO THE RETORT PREPARATORY TO DESTRUCTIVE DISTILLATION 
base for the manufacture of nitrocellulose, one of the most important high explosives. In spite of the fact that special machinery for cutting the linters from the cotton seeds had been installed at most cotton seed crushing plants, the demand grew much faster than the supply. Finally, the laboratory undertook to find ways and means for producing suitable cellulose from wood. Several grades of wood pulp were giren a series of after-treatments to remore the impurities, and the treated samples sent to an arsenal for nitration. It was found that at least two of the after-treatments produced entirely satisfactory material, and plans for the daily production of sereral hundred tons of this pulp had been made when the cessation of hostilities ended the immediate need for such tremendous quantities of high explosives.

\section{Miscellaneous War Time Activities}

Among the many little things typical of the minor actirities of the laboratory was the derelopment of sereral types of shrapnel nose plugs. These plugs were used, early in the war, to replace the time fuses on shrapnel shells during shipment from the munitions plant to the front, and were intended to keep out moisture as well as to protect the machined face and thread forming the shrapnel nose. The threaded and paraffined wooden plugs formerly used. quite frequently swelled during transportation and broke down during attempted remoral. In one type perfected at the laboratory. use was made of the fact that wood shrinks very little along the end grain. Therefore, by so disposing the wood that the threaded portion was all end-grain, it was possible to prevent its swelling and sticking in the hole.

Another type was moulded from a mixture of paper pulp and asphaltic pitch. Still a third, intended to be quick-detachable and quick-attachable as well, was built up of wood with a flexible tongue which caught in the threads and held the plug in place. A quick pull served to break the tongue and release the plug. Just about this time the Ordnance Department decided to put the fuses into the shells at the loading station, and thus dispense with the use of the nose plugs altogether.

The skill and knowledge gained through many year's' study of wood under the microscope, and the collection of authentic wood samples and microscopic wood sections proved to be of very great value 
in many ways. The great bulk of the work carried out by the woodmicroscopy specialists during the war consisted in the identification (as to species) of samples of wood for the laboratory and for various agencies and manufacturers engaged upon war work. Over 18,000 specimens were thus identified during the war. One of the most remarkable series of identifications was of gas mask charcoals submitted by the Bureau of Standards early in the war. It was possible, by the use of the identification keys worked out before the war, to identify the species of wood from which each sample of charcoal had been made.

A distinct phase of the microscopic work was the examination of wood for decay. There are many kinds of stain and discoloration caused by various agencies, among which are certain decay-producing organisms. It is frequently impossible to determine the origin of a stain except under the microscope, and it is most important, especially in aircraft work, that no wood be used which is even slightly decayed and. almost as important, that no wood be rejected simply on suspicion of decay.

Manufacturing and purchasing specifications of the leaders in industry usually embody in a few simple words the results of years of study and experience and they represent the latest and best practice. Much of the progress made by the laboratory in its ten years of research is embodied in the specifications of the various Army and Nary bureaus and of the leading manufacturers in many industries using wood. Several hundred such specifications were referred to the laboratory for criticism and revision, and of these a goodly share were written practically in their entirety at the laboratory.

Instructional work afforded another excellent means of making the laboratory's knowledge effective. The staff had been doing instructional work of various kinds for a number of years and was therefore well qualified to undertake the instruction of various grades of inspectors and operators. The first course for airplane inspectors was given in July, 1917, and succeeding courses at intervals of two or three weeks until the close of the war. About 125 men received instruction in these courses, exclusive of various of the newer members of the laboratory staff.

Courses of instruction for box inspectors, principally for the Ordnance Department, were inaugurated at about the same time as those for airplane inspectors, and continued until after the cessation 
of hostilities. About $90 \mathrm{men}$ in all attended these courses. As an illustration of their practical worth it is reported that a new type of cartridge case box designed by one of these men saved the Ordnance Department $\$ .50 .000$ on the first contract. besides saring $\$ 100,000$ worth of cargo space. Instruction was also given dry kiln operators at various periods, to supplement the individual instructional work being done by laboratory representatives in the field.

In concluding this chapter of the laboratory's history. record should be made of the fact that it could not have been written had it not been for the lovalty and enthusiasm of the individual members of the staff and the spirit of the organization as a whole which overeame seemingly insurmountable obstacles and produced the results.

\section{CHAP'TER V}

\section{FINANCIAT VIITE OF RFSFARCH RESTI'TS}

Closely related as the Forest Products Iaboratory is to much of the business life of the country, and having much of its research applied directly to industrial processes, the acid test of, "does it pay?", is more likely to be applied than it would be if the research conducted here were entirely of an abstract nature. At the same time emphasis should be placed on the fact that much of the laboratory work has been and always will be in the field of pure science, laying the necessary ground work for the applied type of research that finds expression in many of the processes described earlier in this rolume. With far Hung connections such as have been built up in ten years, and with no definite knowledge of the ultimate distance traveled by the methods and ideas radiating from here as a center. it is impossible to answer in full the query, does it pay, or correctly estimate the true financial value of the research results of the laboratory. Any honest estimate. naturally, falls short of the total. 
We do know the operating cost of the laboratory for the past ten years, what has been expended to produce the results so far attained. Briefly, in the ten years of its life, very close to two million dollars has been appropriated to maintain the institution. The war period accounts for a fair portion of this total, so the rearly amount, excluding the time of greatest expansion, is, in the light of accomplishments, low. While the total gain cannot be estimated in dollars and cents, some of the known results, howerer, enable the use of a yard stick which will serve to demonstrate that organized industrial research in wood is a paying investment.

The building and construction trade, for example uses annually about $5 \frac{1}{2}$ billion feet of lumber for structural purposes where strength is important. This material is worth roughly $\$ 200,000,000$. Inrestigation at the Forest Products Laboratory on the mechanical properties of American woods has given knowledge permitting a 20 per cent increase in allowable working stresses in structural timbers. 'This means a possible saring of $\$ \$ 0,000.000$. of which it is estimated that some $\$ 4,000,000$ is already saved each year through use of laboratory data.

Claims for loss and damage to commodities in shipment actually paid by the railroads amount to over $\$ 100,000,000$ annually. Proper nailing and improved designs developed by the laboratory and adopted by the National Association of Box Manufacturers, and through them by many companies and shippers, is estimated to save about one per cent of this loss, a total saving of $\$ 1,000,000$ a year.

Work on water-resistant glues and plywood for airplanes carried on at the laboratory during the war emergency alone saved the War Department a sum rumning into millions in its procurement of such material during a twelve months' period.

Investigations in the use of hull fibre and second-cut linters for pulp and paper have resulted in the establishment of several plants having a potential daily production of 300 tons of paper with an annual sale value of $\$ 8,000,000$.

The adoption of improved methods of turpentining dereloped by the Forest Service has resulted in increased yields and decreased injury to timber with net savings aggregating $\$ 4,000,000$ per year.

The importance of the knowledge which the laboratory had accumulated on suitable methods of drying and on dry-kiln design 
at the beginning of the war, cannot be estimated in dollars. It was put to immediate use in the drying of lumber for all war purposes, as gunstocks, wagon parts, artillery wheel rims and spokes, airplane wing beams and propellers. 'The results have been described elsewhere.

Preventable losses in commercial operations, due to improper air drying and poor kiln drying, have aggregated annually over one billion dollars, at the present price of lumber. How much of this is now being saved through the assistance of the laboratory it is difficult to estimate, but the losses are obviously growing less through the constantly widening sphere of laboratory influence.

The annual saving to American industries directly attributable to the work of the laboratory is estimated at approximately 30 million dollars, with the possibility of a much larger saving were full use made of the results of its investigations. In addition, these results are of much value to Federal and State Govermments and to private owners in the management of forest lands, and are promoting forest conservation by pointing the way to making one tree do the work of two.

Results, of course, camnot be obtained over night, and but ten years has elapsed since the beginning of the work. However, the results obtained so far have clearly demonstrated that over any reasonable period of years, economies resulting from organized research so greatly exceed the expense involved that there can be no questions as to its value.

As a side commentary on the financial aspects of forest products research, the practical value of the work done at Madison has received wide foreign recognition. Based on a study of this laboratory a similar institution has been installed by the Canadian gorernment; also in South Africa, India, and Australia, the various local govermments have called men of the laboratory staff to direct research in forest products particularly in the seasoning and kiln drying of timber species commercially used there. In practically every country on the globe are laboratory contacts, largely with wood-using industries. established through requests for information arailable at the laboratory and the recognition of the practical value of this information. 


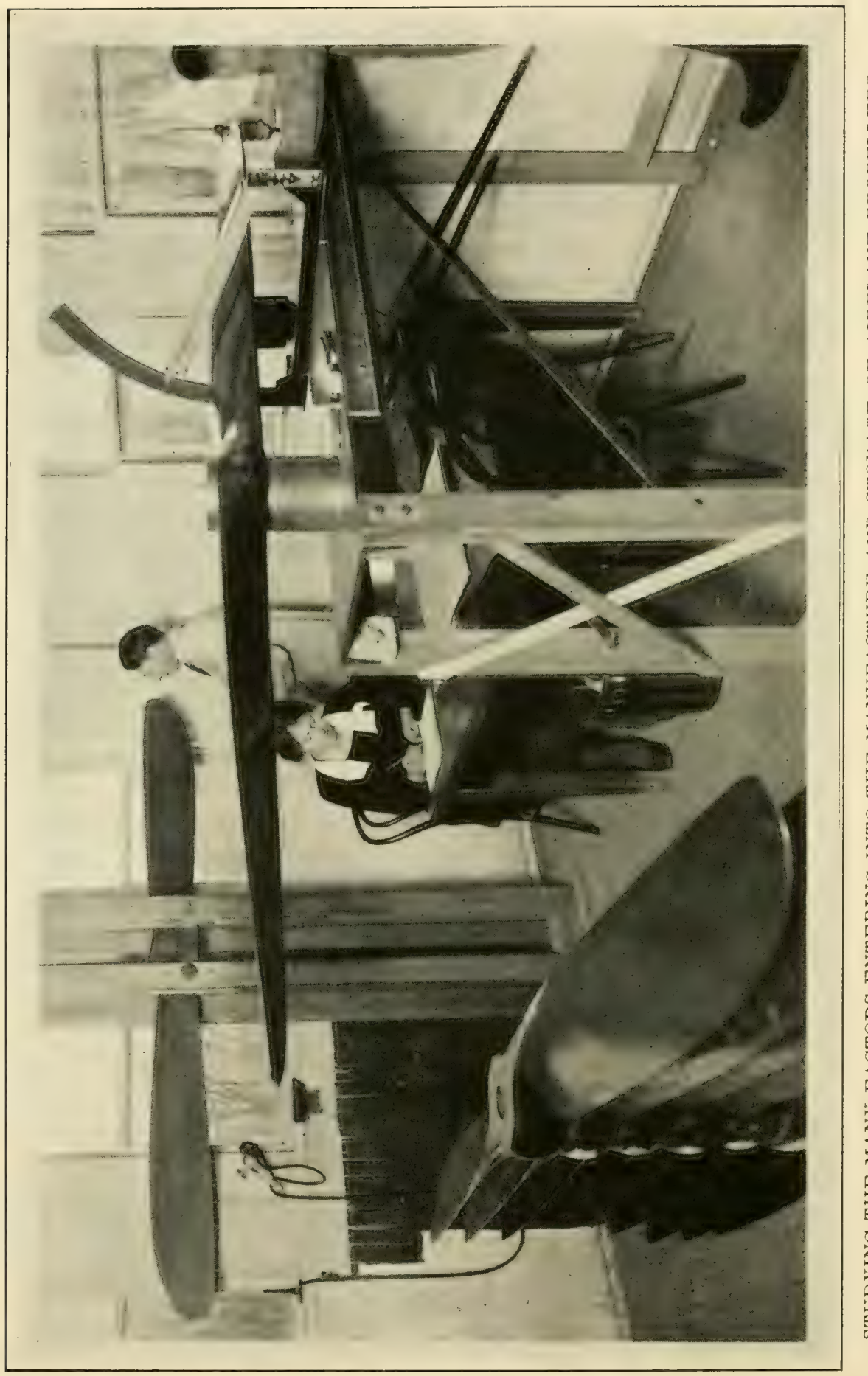

吾) 


\section{CHAP'TER VI}

\section{FUTCRE RESEARCH IN FORES'T PRODUC'TS}

The laboratory, passing, as it did, through the war with a large measure of service to its credit, is now in the post-war adjustment period, sailing out on a new tack. The immediate realigmment of forces, following the armistice, the reduction in persommel, the cleaning up of war projects. and the application of facts learned during the war to peace time industries and processes, have been told earlier in this book. 'The two years that have elapsed since the armistice have seen the adjustment largely completed.

What of the future, of the problems still unsolved, the fields of research visioned from this point, the beginning of the second decade of the Forest Products Laboratory's existence? Such a rision exists. and its kernote is the reduction of the annual drain upon the remaining forests of America by more economical utilization. A rision of service to the wood-using industries of the country and a desire to stop the widening of the alarming gap in America's economic fabric-the shortage of timber to meet our present standard of cirilization-are essential parts of this vision.

Some of the problems facing the wood-using industries are given briefly below, together with their relation to past and present work of the laboratory. A number of phases of these problems are being worked on now, in so far as prorision has been made to finance them. either through Federal appropriation or through cooperative funds.

\section{The Mechanical Properties of Wood}

The lahoratory's work in this field has been centered upon determining the mechanical properties of the different important commercial species of the I'nited States. At the outbreak of the war some 130 different species had been tested, and the results of these tests formed the foundation for practically all of the laboratory's war work where the strength of timber was a factor. This data, still incomplete, 
likewise forms a fundamental basis for determining the design and use of wood and things made of wood; effect of defects; the selection of proper woods for various uses; the technical studies of wood-using industries; the standardization of grading rules and building codes; and the economic utilization of structural timbers.

When it is realized that more than one-half of the timber cut each year is for structural use, the savings possible because of the accurate knowledge of the mechanical properties of the different woods may be appreciated. For example, one-sixth of the 40 billion feet of lumber consumed annually is in the form of boxes and shipping containers. It has been estimated that by developing balanced box construction it will be possible to use from 25 to 50 per cent less lumber (equivalent to a saving of from two to three billion feet of lumber annually), and at the same time provide containers equal to or better than those now used. The demands upon the laboratory for information relative to proper box construction are far in excess of what it can handle; and while it has made a good many tests of different types of boxes, it has scarcely scratched the surface of the field of possibilities.

Another field in which the mechanical properties of wood should be studied is that involving the steam bending of wood. 'This is a field in which the percentage of waste is exceedingly high. particularly in the vehicle, furniture, and cooperage industries, due to the high percentage of breakage in the wood when under bending pressure. The problem involves many factors. It is one upon which the laboratory has been able to do practically nothing.

Other profitable fields are those involving the development of built-up trusses, thus making possible the utilization of low grade lumber; the development of joints and fastenings in timber construction; the effect of growth conditions on the properties of wood, and especially the determination of the differences in the mechanical properties of the second growth timber now coming to merchantable size, and upon which the industries will be more and more dependent; the development of laminated construction permitting greater utilization of small sized and low grade material; comprehensive tests on full sized timbers used as columns for building construction; the standardization of building codes so that each species will be giren its proper place, based upon its true mechanical value, thus avoiding the large 
waste now resulting from the inefficient selection and utilization of material.

\section{The Preservative Treatment of Wood}

This is a large field of conservation possibilities. 'To date the laboratory's work has been directed mainly to determining the penetrability of different species with available commercial preservatives and to dereloping more efficient processes of treating wood to protect it against decay. Recent estimates show that the annual loss due to decay in varied forms of structural timbers, such as railroad ties, mine timbers, piling, bridge timbers. posts, poles, etc.. amounts to as much material as is annually lost by forest fires. Wood preservation has been demonstrated as commercially profitable, but its practice is not as general as it should be, and preservative methods are still susceptible to much improvement.

'The laboratory has also done a limited amount of work on the problem of fire-proofing wood, but has not had the facilities nor the organization to carry it to the point of success. Of the annual fire loss in this country a great deal could be prevented by the development of more effective and cheaper methods of fire-proofing wood. Research in this field is necessarily expensive, but the possibilities of saving both timber and property are so great and important that work of this character should not be long postponed.

Great quantities of mine timbers are destroyed annually by decay because they are not given preservative treatment. 'The amount of timber used in the mines throughout the country is staggering, and the laboratory should have men in the field most of the time conferring with mine officials, demonstrating the ralue of wood preservatives and promoting their use. Much of the necessary experimental work on the treatment of mine timber has been done, and its value has been conclusively proved, but the laboratory has not the organization to carry its information to the mine and demonstrate its application and use.

Similarly, great quantities of timber used as piling in salt water are destroyed annually by marine borers. Incidents may be cited where large docks and over-water buildings erected at great expense have been undermined and practically destroyed within a year or two 
after construction, due to the attack of the marine borers. The laboratory has done some work on this problem cooperating with a committee of business men on the West Coast, but the problem of finding a more effective treatment to protect piling against these borers is one calling for urgent consideration, both from timber-conservation and property-maintenance standpoints.

Because of the gradual depletion of eastern woods, railroads in the East and Middle West are being forced more and more to use the far western species for ties and structural purposes. Many of these woods are of the so-called inferior species, and they must be given preservative treatment in order to render effective service. A number of them, however, take treatment with difficulty, and the present investigations of the laboratory are inadequate to recommend treating processes which are wholly satisfactory. The laboratory plans to continue its work on these species, but its organization and finances are inadequate to attack it on the scale its importance justifies.

During the war the laboratory was called upon by the Army and Navy to conduct a series of researches involving the development and use of water-resistant glues. The results of this work have found wide application for peacetime uses, including the manufacture of plywood, laminated articles, airplane construction, etc. The development of most effective glues in relation to the service which wooden products should give, is, however, still in its infancy, and it is difficult to predict what economic savings may result from intensive research in this field.

Laminated wood is becoming increasingly practical, and developments in its manufacture hold out promise of great improvement in wood utilization practice. They may eren have a profound effect on the future methods of forestry in making it unnecessary to raise trees of large size. Even under conditions existing today, the development of laminated construction will open a market for the profitable use of millions of feet of small material now wasted. The single discovery of a process of making a durable water-proof glue which will withstand outside climatical conditions will open a great field for laminated products. 


\section{The Chemical Utilization of Wood}

From the standpoint of utilizing waste, this is an important field calling for further derelopment in our knowledge of the chemistry of wood and the application of that knowledge to the chemical and byproducts industries. The laboratory has had a small force of specially trained men engaged in studying the processes by which some of the more important chemical products, including ethyl alcohol, methyl alcohol, acetic acid, tannin, etc., are derived from wood. It has not been able to advance far in a fundamental study of the chemistry of wood cellulose or to investigate in a comprehensive way many other problems which hold out promise of utilizing present waste.

It has been stated that in the waste resulting from the lumbering and milling of southern pine there are values in chemical products greater than the ralue of the lumber manufactured. The problem is to work out practical processes for reclaiming these values. One of these products, for example, is grain or ethyl alcohol. The laboratory has done considerable work in developing efficient processes for converting sawdust and wood waste into ethyl alcohol and the process is now on a commercial basis. This alcohol is of high purity. It is an efficient fuel for gas engines and finds wide use throughout the chemical and pharmaceutical industries. To extend the use of the process further, intensive and exhaustive investigations to secure greater efficiency and lower production costs are desirable.

Another example of how new uses for wood waste may be discovered through research is the recent development by the laboratory of a stock food prepared from white pine sawdust. Results from the preliminary feeding of this material by the University of Wisconsin indicate that a carbohydrate food from sawdust of many coniferous species may be made and that it has a value equivalent to one-half that of barley and similar stock foods. Conservative estimates indicate that it can be produced under present conditions at approximately $\$ 7.00$ per ton.

Another striking and important field embraces the problem of providing a future supply of wood alcohol obtained primarily by destructive distillation of hardwood. Many of the basic industries are dependent upon wood alcohol, and no other means of producing this 


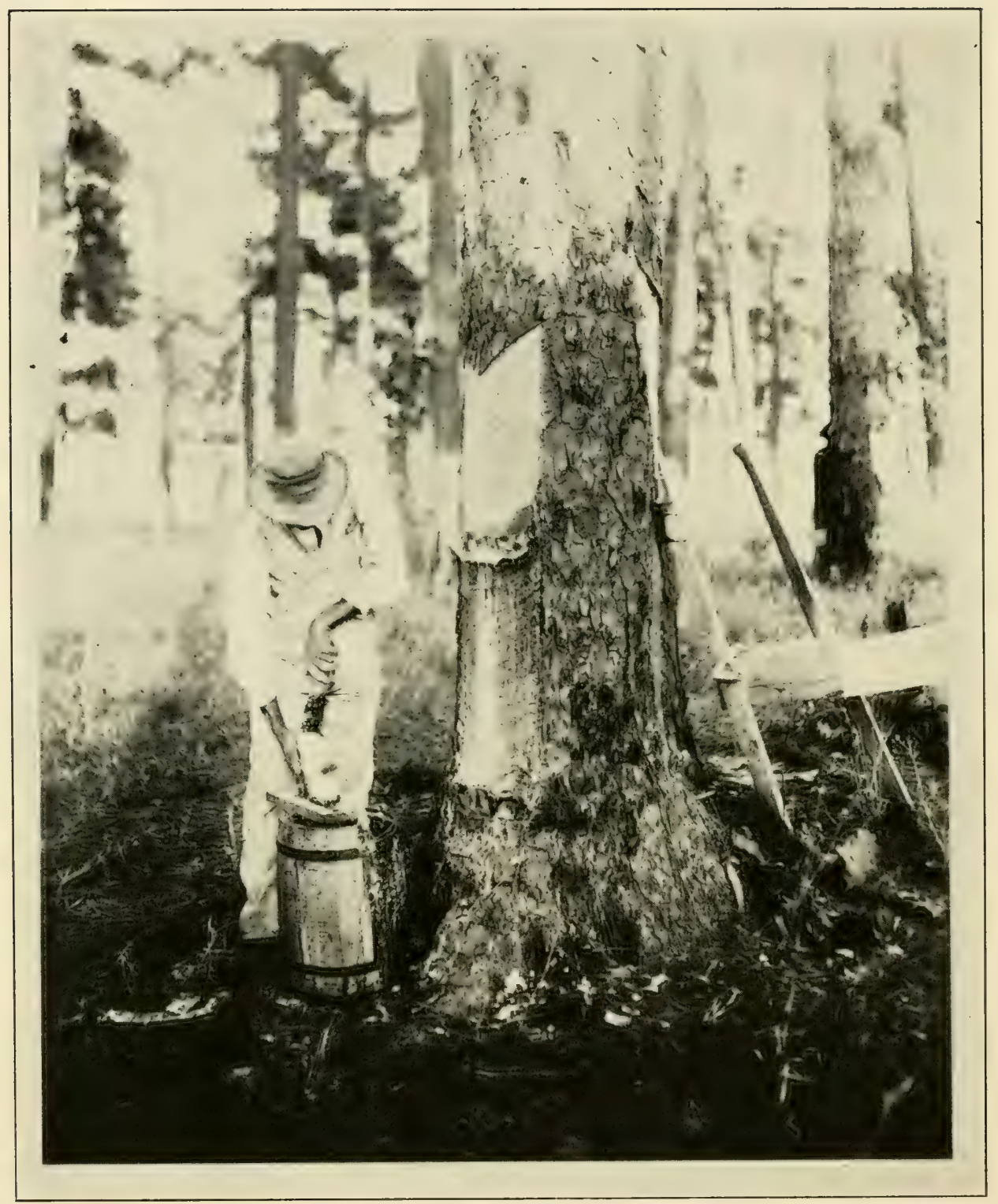

FOREST SERVICE IMPROVEMENTS IN TURPENTINING PROCESSES REPRESENT AN ANNUAL SAVING TO INDUSTRY OF $\$ 3,000,000$ 
product have yet been discovered. The growing scarcity of hardwoods makes the problem of its future supply increasingly acute. 'The laboratory has given some study to the different processes now used in wood distillation, and during the past year it has developed certain modifications which indicate that the rield of wood alcohol from a given quantity of wood may be increased about 50 per cent over the present normal production. It is important that this whole field be studied more comprehensively than the laboratory is now able to do, not only in order that processes may be made more efficient, but that the productive value of new woods may be determined.

Still another field, in which better methods of utilization are urgent. embraces the turpentine and rosin industry. This industry is in a precarious situation hecause of the rapid exhaustion of southern yellow pine which is its main and practically only source of supply. Not only is it one of the oldest industries in the country but it gives the United States the leadership in the world in the production of turpentine and rosin. It is imbued with old ideas and in many cases is following old customs with consequent waste of raw material. While the laboratory has already developed methods which have elininated some of this waste and have increased the yield of both turpentine and rosin. further work is desirable in order that the life of the industry may be prolonged by developing maximum production from the longleaf pine timber now remaining.

There are many other lines which gire promise of reclaiming wood now wasted and of increasing the value of products already being reclaimed. Among these may be mentioned studies to improre fire boxes and grates so als to get the maximum heat from wood waste when burned in fire plants: the production from wood of absorbent and decolorizing charcoal; the effect of rarious species used in food containers on the odor and taste of the contents. and the methods of treating wood to remove odor and taste: and methods for decolorizing rosin obtainable from pine stumps. thus making it comparable to that obtained from the living tree.

\section{The Utilization of Wood for Pulp and Paper}

It is umnecessary to call attention to the importance to the nation of the pulp and paper industry. Its products weave into every other 
industry and almost every activity of the nation. Under present methods of converting trees into pulp this industry is dependent for its raw supplies upon three per cent of the standing timber remaining. This is due to the fact that present processes are commercially adapted to a very few species only. This accounts, in part, for the fact that the pulp mill industry in the East and the Lake States faces exhaustion of local timber within a decade or two, and the future of the industry for the country as a whole rests upon the development of processes which will make it commercially practical to use species other than those now being used, especially western woods which comprise over 60 per cent of our remaining timber.

The laboratory's work in the pulp and paper field has been focused primarily in determining the value of our different species for pulp and paper. More than 70 different species have been studied. A process was recently developed, for example, whereby a high grade book paper may be made from southern yellow pine. This process, put to commercial application, makes available the southern pineries as a source of book paper and thus relieves the drain upon the species now used, the supply of which is rapidly being exhausted.

A further field of research work promising high returns, particularly in the East where the industry has been long established, embraces the prevention of waste and the greater utilization of the timber supply now available. It is conservatively estimated that with proper research to develop increased utilization, our remaining pulpwood supply will produce, unit for unit, double the finished product that is now being obtained. Present chemical processes applied to over 30 per cent of the wood used in producing newsprint, for example, convert less than 50 per cent of the raw wood into paper. The remainder passes off as waste. It contains valuable chemical constituents.

Tremendous losses occur in the storage of pulp wood and of the manufactured pulp. These losses are placed by the industry at about $\$ 5,000,000$ annually. They are due to fungus decay which the mills. to date, have been unable to combat, owing to the lack of knowledge of the fungi and their methods of attack, and of proper methods of control. Within the past year (1920) the laboratory has made a study of this problem in cooperation with the industry which has supplied a large part of the necessary money to conduct the work. Preliminary results indicate that much can be done to check the decay by applying 
proper methods of storage to both pulp and pulp wood and by treating the pulp with antiseptics. These possibilities should be fully investigated, and the limiting concentrations of antiseptics already found effective should be clearly determined.

Much more comprehensive work should be done in studying the chemistry and fundamental practice of the cooking processes, as at present conducted by the pulp and paper industry. These processes have not been improved to any degree for a long period, and there appears to be little doubt but that there is great room for improvement, not only in cooking but likewise in the bleaching processes.

Over 50 per cent of the weight of the wood that enters the chemical pulp mills, or over 2,000,000 tons, is now dissolved in the cooking liquors. Of this less than a third finds ultimate use and that merely as a fuel. It contains, however, methyl and ethyl alcohols, acetones, acetic acid, various oils and materials from which it should be possible to obtain a vast number of other valuable products. The pulp-maker, however, is not essentially a chemist and avoids by-products processes that are purely chemical. It is a problem that should be undertaken by the research men.

\section{Physical Properties of Wood}

'The laboratory's work in this field has been along two main lines: (1) The development of efficient methods of kiln drying lumber, and (2) the identification of woods and the relation of their structure to their properties. The latter is important and fundamental to the determination of the penetrability of different woods by preservatives, fire-retardent solutions, coatings and glues, the explanation of phenomena occurring in kiln drying, such as shrinkage, casehardening, etc., and the detection and effect of decay and other strength-reducing factors.

Considerable work along both lines has been done by the laboratory, but the respective fields are so large and the laboratory's facilities so small in proportion, that many of the more fundamental problems remain incomplete. The seasoning process is an especially weak link in the chain of processes transforming the log into the finished product, and the annual loss incident to poor seasoning runs into many millions of feet. The laboratory has worked out some of the funda- 


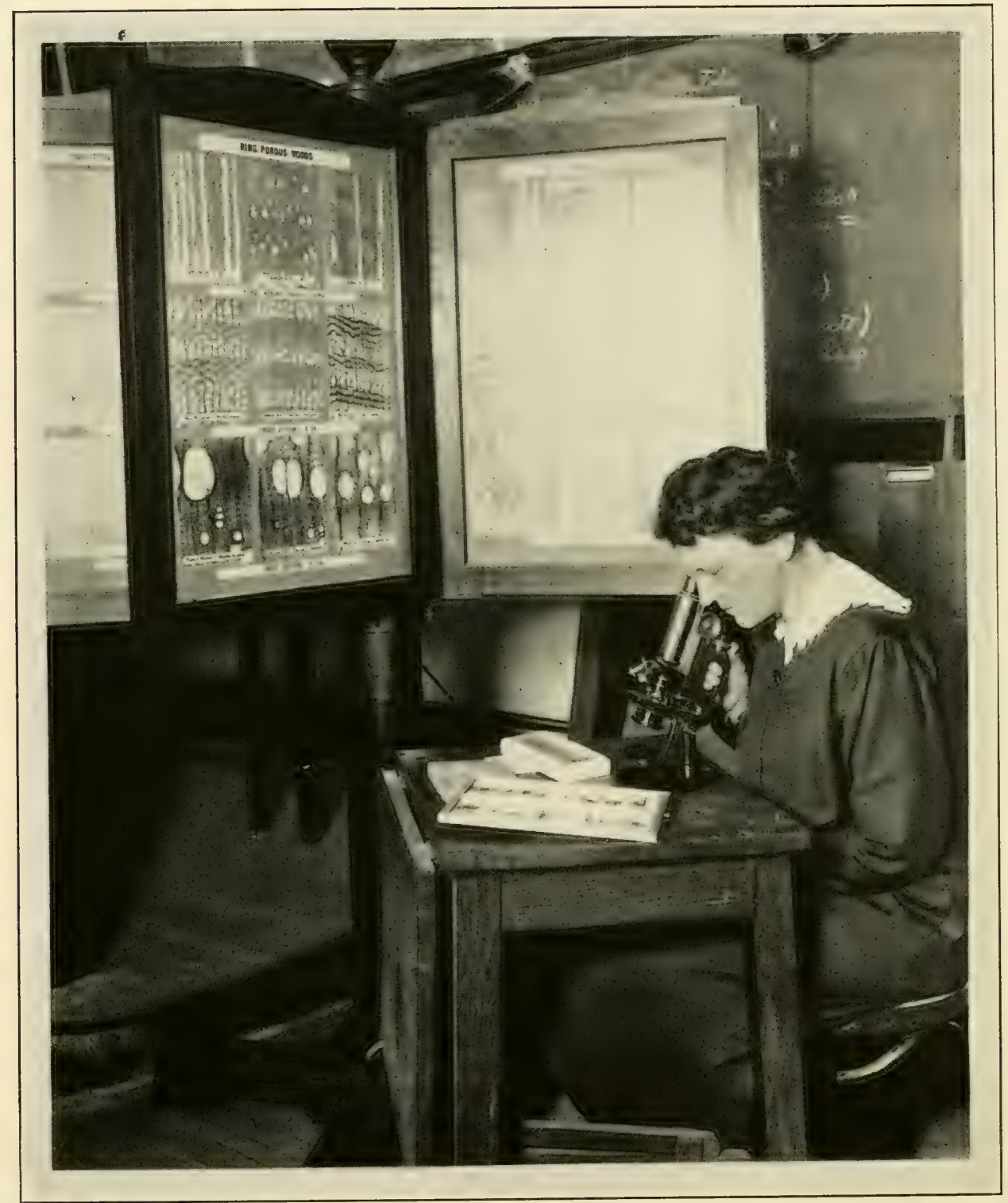

WOOD TECHNOLOGY-THE MICROSCOPE IS USEFUL IN IDENTIFICATION AND IN THE STUDY OF DECAY, PRESERVATION, COATINGS, AND OTHER FACTORS 
mental phrsical laws governing the drying of wood and the relation of moisture to strength.

This data forms the groundwork whereby characteristic industrial problems involved in the seasoning processes have been dealt with extensively and through which this country, shortly after its entrance into the war. became recognized as the highest authority in the world on the kiln drying of wood. 'This data, incomplete though it still is, has already done much to promote more scientific and more efficient kiln drying of wood.

The laboratory has not only worked out kiln-drying schedules for a number of our more important species. but it has dereloped two types of dry kilns. one especially adapted to slowly drying refactory hardwoods and the other to rapidly drying softwoods. Within its limited means it has given assistance to lumber companies and woodworking plants in designing and remodelling commercial kilns, and through experiments it has developed methods of kiln drying many kinds of lumber green from the saw, reducing. in some cases, the time of drying as much as from 4 or 5 years to 90 or 100 days.

With an expanded organization it would be possible to bring about very generally better methods of drying wood, by sending laboratory representatives to the different plants and helping them to solve their problems upon the ground. In the course of a year the laboratory receives many such requests, but is able to meet relatively few of them without interrupting its regular work.

'There is, furthermore, great need for more extensive study of auxiliary dry-kiln apparatus in order to simplify the operation of dry kilns: the development of humidity control in shops and storage sheds; the improvement of drying schedules for many species upon which conclusire investigations hare not yet been possible: and the derelopment of improred methods of air seasoning lumber in order to reduce degrade to the minimum.

\section{Industrial Investigations}

This field might be termed "the technical study of the efficiency of wood conversion processes". It is a field in which the laboratory's work has been exceedingly limited, owing to the fact that an adequate organization has not been available. Some of the problens involved 
are the standardization of lumber grades and specifications; effect upon the cost of production of various sizes and grades of logs; efficiency and character of mill operations; studies of processes of manufacturing furniture, vehicle, cooperage, etc., and the wood waste incident thereto; and the correlation of the properties of different species to their most efficient use.

As an example of the tremendous possibilities of conserving timber through such studies the dimension-stock problem may be mentioned. The total requirements of the secondary wood-using industries for wood in dimension stock sizes amounts to eight or nine billion feet annually. Of this amount, some five or six billion feet is small dimension stock which is cut from standard lumber sizes after the lumber has reached the wood-using factory. The extent to which this practice causes waste cannot be accurately gauged, but it is the opinion of many of those who have carefully studied the problem that a large percentage of this small dimension stock material could be cut at the mills from material now wasted.

The laboratory plans to assign a number of men to this dimension stock problem with the ultimate object of determining by accurate studies the most efficient process by which the standing tree can be manufactured into the dimension standards required by the woodusing industries. This is merely one of the many important problems which should be undertaken in the same field.

\section{Estimated Saving, Ten Billion Feet}

The foregoing indicates, in a very broad way, the character of the work in which the laboratory is now engaged and the large and profitable field before it. There can be no doubt of the value of research work of the character which is being done, whether performed by the laboratory or some other organization. It is one of the most effective and practical measures for meeting the forest problem. There is no extravagance in the statement that it is entirely feasible to save ten billion feet annually through better utilization. 


\section{CHAPTER VII}

\section{HOW TO USE THE LABORATORY}

To a greater or less degree every wood-using industry of the country is a prospective user of the Forest Products Laboratory or the data available there. This statement is made with a fair appreciation of the vast complexity of the inter-relation of the many different aspects of this great primary industry. Sooner or later in the long process from the forest giant growing peacefully in the fastness of the far-away hills to the finished article of commerce containing wood in its make-up, a number of contacts of common interest will be developed by every one of these industries, however unrelated the ultimate products. Economies in logging, in saw mill practice, in kiln drying, in the elimination of loss all along the line, in the development of means of utilizing what is now waste by-product, all these will ultimately affect the wood user through cheaper or more stable supplies of raw material, whether this user be a man building a house, a plant turning out wagons, a pulp manufacturer, or the maker of wooden mouse traps. The laboratory, through its contact with all phases of forest products, has something of interest to all of these.

The prospective user should think of the laboratory as a big reservoir of facts bearing on his industry, which he, as a taxpayer, has helped to create and which he can tap on demand. If he is engaged in a business that has a relatively wide bearing on wood and its use-for instance, wood preservation, pulp and paper, kiln drying-he will find here information in great detail, even the most complete data in existence bearing on his problems. Many minor fields and side trails of the rast ramifications of the wood-using industries have also been probed to a greater or less degree, or, if problems in these lesser lines have not been specially covered, light may be thrown on them through knowledge obtained by work done in related fields.

"Ask and it shall be given you", might be the first suggestion for using the laboratory. The daily quota of laboratory mail contains many request : from all parts of the T'nited States and usually a num- 


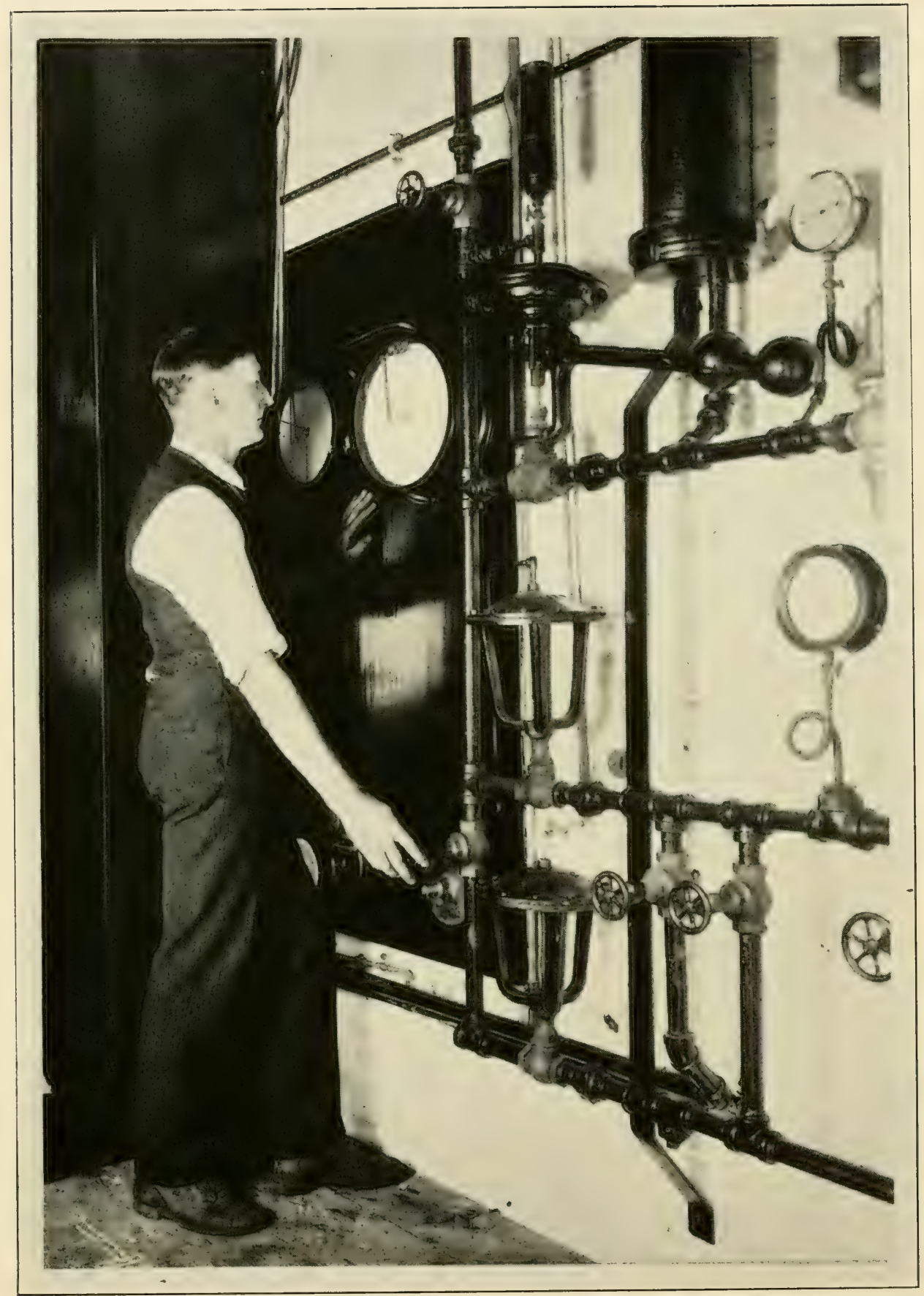

THE CONTROL AND OPERATION END OF A DRY KILN AT THE LABORATORY 
ber of far corners of the world for information, publications, and advice on general and specific phases of problems arising in every conceivable sort of wood-using industry. If a problem comes within the field covered by the laboratory - and this field has been indicated in other chapters of this book - the mail and telegraph will tap the laboratory's reservoir of information on demand. Many companies and individuals have found personal conference of value, and this medium of communication with the industries is welcomed. Further, the laboratory is always available for either a short or extended study and investigation of its methods and lines of work not only by American citizens but by accredited representatives of foreign wood users or governments.

Naturally, for any of the services rendered as just outlined, there is no charge. A rast amount of material-reports and articles, printed bulletins. photographs and diagrams has been prepared for distribution and, as far as arailable, will be fumished gratis on bona fide request.

With the establishment of fundamental principles and processes, and the outlining of standard methods of testing, the laboratory gradually has entered, in the past two years, a new phase of relations with the wood-using industries, namely, cooperative service. While essentially a government activity conducting research in forest products for the benefit of the people of the United States, its purpose is best served when the results of its work are of broadest application and of most permanent ralue in promoting the economical use of wood.

The laboratory is maintained and operated by annual appropriations made by the Congress of the United States. These appropriations are based upon general estimates of work to be undertaken during the ensuing fiscal year, so that the amount of moner appropriated by Congress for the laboratory's use must be spent in accordance with an annual program of work. In keeping with the purpose of the laboratory, it is the policy of the Government to make this program, in so far as possible, one of fundamental research, the results of which will be of greatest benefit and of most lasting ralue from a public standpoint. In addition. it is necessary to provide sufficient moner to disseminate its data and information. free of charge, through correspondence, which arerages 3,000 letters a month, and through reports and special articles. 
From the foregoing, it will be seen that the laboratory does not have available money with which to undertake projects not included in its regular program of work. The amount annually made available by Congress must be spent in accordance with a general program approved by it. This sum, however, is much less than could be expended effectively with the laboratory's present facilities.

Recognizing the further opportunity for service, the laboratory has adopted the policy of undertaking cooperative work up to the point where it can be handled efficiently and without disruption of its regular program of fundamental work. A number of important considerations influenced the Forest Service in offering this cooperative service, among which are:

(1) 'The Forest Products Laboratory is the only organization of its kind in this country fully equipped to conduct intensive research in all lines of wood utilization and readily available to the lumber- and wood-using industries. During the ten years of its existence, it has built up a great fund of scientific information on wood which is usually of direct value and application in the solution of specific problems, thus making it possible to solve many new problems with a minimum amount of new research. The idea behind its cooperative service is thus to place its facilities. organization, and fund of information at the disposal of the industries under the best terms possible and practicable. The alternative would be to attempt no research except that provided for in its approved program.

(2) A certain amount of cooperative work, it is believed, is a healthy thing for an organization of this character. It not only increases contact between the laboratory and the wood users, thus stimulating appreciation of one another's problems, but it adds to the general fund of scientific information on wood. While all information in possession of the laboratory is disseminated free of charge, much of this information is incomplete when applied to specialized commercial problems. Cooperative service makes available to the industries an opportunity, which otherwise would not be available, to supplement by special research at minimum cost any incomplete data in possession either of the laboratory or of the industry. And it tends to utilize the full capacity of the laboratory. 


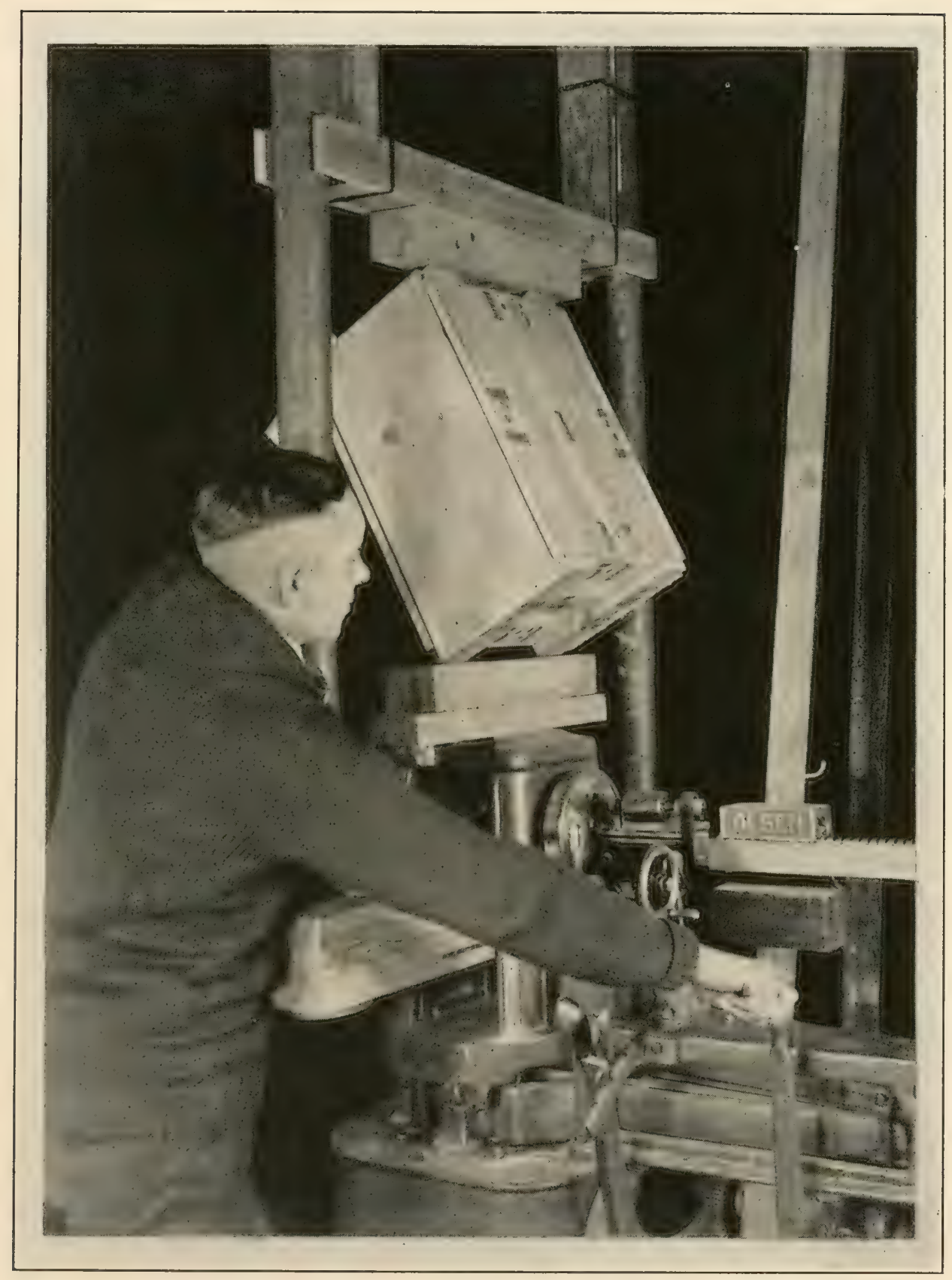

COOPERATIVE BOX WORK-A STUDY OF DIAGONAL COMPRESSION 
In offering cooperative service, however, it has been necessary to place certain limitations upon the work which will be accepted. The laboratory does not desire to engage in mere routine testing, and it is not its purpose to do so. To meet all requests of this character would require many times its present appropriation. Especially does it avoid a type of routine work that could be readily done by an industry through the installation of simple testing machinery, at reasonable cost, by the industry itself. Advice on such installations will invariably be given if desired. It is not its purpose to promote one product as against another, but to present facts which will enable the public and the industries to put wood to its best use. It has therefore adopted as one of its underlying principles of this cooperative work that it will not accept any project the results of which will not be of some general value and application. As between two pieces of cooperative work. only one of which the laboratory could undertake, the one would be accepted which it appeared would give results of broadest application. 'The conditions under which this cooperative service is rendered are:

(1) 'The laboratory will plan and carry out the tests of investigations desired and will prepare the necessary report. 'The cooperator will pay all expenses incidental to the work. He will be charged actual cost of work only. 'The laboratory does not render' cooperative services on a profit basis. In cases where the work is of direct value in furthering the regular research program of the laboratory, the cost is often divided between the laboratory and the cooperator.

(2) The laboratory shall have the unrestricted right to publish and distribute the results obtained from the investigation. 'The cooperator shall not publish for general distribution any statements or reports commiting the laboratory unless specific approval is first obtained. Experience has shown this restriction necessary as a protection to the laboratory, the cooperator, and the public against possible misuse of data obtained and against dissemination of incomplete and misleading results. The value of the laboratory's work depends upon the authenticity of its results and the confidence which the public and the industries can place in them at all time.

(3) Results are not subject to private patent. 
'The cooperative service offered by the laboratory is thus an effort to aid the industries, at minimum expense, in a larger way than would be possible by limiting activities exclusively to the work authorized by annual appropriations from ('ongress. It in no way commercializes the work of the laboratory, because all information available on any phase of wood utilization is furnished free upon request or through personal consultation. But special problems, involving additional data and investigations outside its regular program of research, can be handled only under the conditions stated.

Individuals or companies, by referring their wood problems to the laboratory, may obtain in advance a statement of the tests or inrestigations thought necessary to their solution and an estimate of the cost. Communications should be addressed to the Director. Forest Products Laboratory, Madison, Wisconsin. 
PART II 


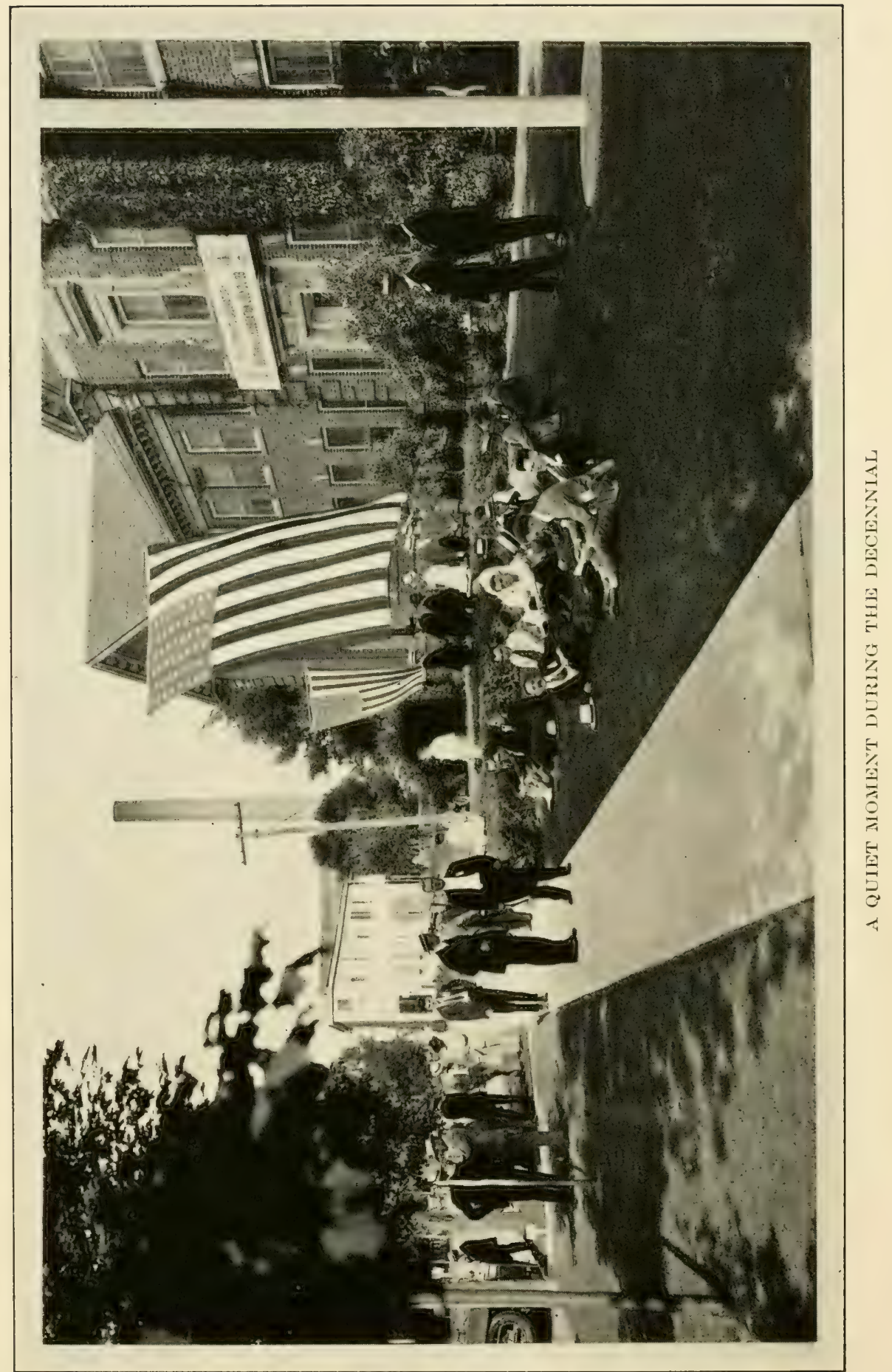




\section{THE DECENNIAL}

'The culmination of the first ten years of the life of the laboratory came with the Decennial Celebration on July 22 and 23, 1920, at Madison, Wisconsin. 'That the ten years was fruitful of no small measure of service and establishment of good will among those whom the laboratory was intended to serve is shown by the registration during the two days' festivities, which were attended by 269 visitors from 22 states and Canada and Porto Rico. Largely drawn from the nation's wood-using and forest and lumbering interests, these representative business men and friends were given opportunity to study the derelopment of the laboratory as it stands today in physical equipment and facilities for future service. On the part of the laboratory, it was the laying of a new foundation stone for the erection of a greater laboratory, the gaining of inspiration to press on to the making of a new ten-year record. Service to the woodusing industries of the country indirectly, and primarily the extension of the usefulness of America's forests, so vital to the welfare of our present standard of civilization, were the keynotes of the decennial.

The program and proceedings of the celebration follow. 


\title{
PROGRAM OF THE DECENNIAL CELEBRATION FOREST PRODUCTS LABORATORY
}

\author{
Thursday, July 22, 1920
}

REgistration

Headquarters have been established at the Park Hotel on Capitol Square and all are requested to go there for room reservations, registration, banquet tickets, train schedules and other information.

10:30 A. M. General Assembly

Agricultural Hall, University of Wisconsin

H. F. Weiss, Chairman, Consulting Engineer, C. F. Burgess Laboratories and Former Director, Forest Products Laboratory.

"Legislative Measures for Forest Conservation" The Honorable Emanuel L. Philipp, Governor of Wisconsin.

"Translating Knowlenge Tnto Power"

E. A. Birge, LL.D., S.C.E., President of the University of Wisconsin.

"The Forest Pronucts Laboratory"

C. P. Winslow, Director, Forest Products Laboratory.

12:00 NOON LUNCHEON

Gymnasium, University of Wisconsin

1:00 P. m. Inspection of the Forest Products Laboratory

(Report at the main building of the laboratory on University Avenue and join a party with a guide.)

The Home Economies Department of the University of Wisconsin will hold a special demonstration for the benefit of visiting ladies. 
4:00 P. M. RECREATION

Automobile tour of the city, boating and swimming.

$7: 00$ P. M. BANQUET

Gymnasium, University of Wisconsin

Burr W. Jones, LL.D., Toastmaster.

"Forests and National Prosperity"

Lieutenant-Colonel W. B. Greeley, Forester, Forest

Service, United States Department of Agriculture.

"Scientific Research axd the Submarine Detector" Illustrated talk by Prof. Max Mason, Research Specialist of the National Research Council.

Friday, July 23, 1920

10:00 A. m. General Assembly

Agricultural Hall, University of Wisconsin

John Foley, Chairman, Forester, Pennsylvania Railway System.

"Sone Problens of the Pulp and Paper Industry" D. C. Everest, Secretary and General Manager, Marathon Paper Mills Company.

"America's Place in Industrial Research"

H. E. Howe, Chairman, Research Extension Division, National Research Council.

"Some Problems of the' Lumber Industry"

W. A. Gilchrist, Member of the Forestry Committee, National Lumber Manufacturers' Association.

12:00 NOON LUNCHEON

Gymnasium, University of Wisconsin 


\section{A D J O UR N M N T}

\section{SPECIAL ANNOUNCEMEN'TS}

A Wood-L'sing Industries Conference on a National Forestry Policy will be held on July 23 at 2:00 P. Mr. in Agricultural Hall, University of $W$ isconsin. All are invited to attend this conference.

A meeting of the Executive C'ommittee of the American Wood Preservers' Association will be held on the afternoon of July 22.

Deans of Forestry and Engineering Schools will meet the morning of July 24 to consider a curriculum for Forest Engineers.

'There will be a meeting of the Inter-regional 'Technical Committee of the National Lumber Manufacturers' Association on the morning of July 24.

'The Venetian Night Regatta of the Eniversity of Wisconsin will be held at the foot of Park street on Lake Mendota on the afternoon and evening of July 23. This is a gala event. 


\section{FOREST PRODUCTS LABORATORI DECENNIAI. CELEBRATION}

\section{Ixtroductory Speech}

\section{H. F. Weiss, Chairman}

Friends of the Forest Products Laboratory :

Ten years ago the state of Wisconsin, through its university, entered into a cooperative agreement with the Federal Govermment through its Forest Service to establish an institution for studying the properties of one of our country's great natural resources, namely. timber.

We are assembled here today to celebrate the first ten years of work of this institution, to take an inventory of what has been accomplished, and to interchange views in reference to developing plans for a bigger and better future. I think in these days of high taxes. which may go even higher, it is well for all of us to become much better acquainted with our Government, to know what our Govermment is doing for us.

The tendency of the time, I think, particularly on the part of Goremment and industry, is for these two to work too much apart, this being due largely to a lack of familiarity with each other. I believe it is particularly necessary for the Goremment and the industries to cooperate more whole-heartedly if our country is to play a prominent part in the commerce of the world. In the Forest Products Laboratory the Gorernment has established an institution which is doing much direct good for all of the wood-using industries and indirectly is doing good for all of us, because all of us use wood in some form or other. On hehalf of the Celebration Committee I want to thank each and everyone of you for coming here and for the splendid and loyal support which you have given. Without your support this celebration could not have been held.

It now gives me great pleasure to present the man who stands at the head of the great commonwealth of Wisconsin, which has done so much to make this work in studying forest products a successful reality-Governor Philipp. 


\section{"LEGISLATIVE MEASLRES FOR FOREST CONSERVATION"}

\section{Emanuel L. Philipp, Governor of Wisconsin}

\section{Mr. Chairman, Ladies and Gentlemen:}

In behalf of the state I want to bid you welcome, particularly those of you who have come from other states and from other sections of this state to this meeting. It is an important meeting in many ways and one which will result, I am sure, in some good. I welcome you to this great university, the capital, and our state in general; and I hope that when you leave here the people and the surroundings that you have been in will leave a good and lasting impression upon you.

To me has been assigned the subject of "Legislative Measures for" Forest Conservation". Before I attempt to speak upon that subject, howerer, I am going to review briefly what I believe to be the waste of forest materials during the nineteenth century. I do this because I was reared in the state of Wisconsin; I knew something of the timber supply of earlier days; I have been a lumberman, and I am going to speak to you from the lumberman's standpoint, not only of the waste in $W$ isconsin, but of the waste that we have seen in other states, particularly in the South, and the new conditions and the better understanding that the people no whave of timber values since they began to see it disappear. I think that would better illustrate the necessity of legislation for timber conservation than mere legislative discussion of the subject.

The state of Wisconsin, as you all know, had a great timber supply. I think back to the sixties when men went to the northern pineries, bought forty acres of land, and cut around that forty acres for three or four years. That was a common custom. There was so much timber in northern Wisconsin that it was the general belief among our citizens that the supply was inexhaustible. To that supply was added the then only partially-known supply of northern Minnesota and the great supply in the state of Michigan. There was so much timber to be had and lumber was necessarily so cheap that only the very best qualities could be used and sold for a very common and 
ordinary purpose. I recall the time out here on the Wisconsin river, where I lived as a small boy, when $1 \times 6 \times 16$ fencing had to be free of knots. A farmer would not accept a fence board, a cork pine fence board, that had a knot in it; bridge plank had to be practically clear; and so it was with all the lumber that was used at that time. You of younger years who have probably had something to do with the wrecking of old houses have learned that the "piece-stuff", so called among lumbermen, used in those days was practically clear material. Now, every lumberman knows that when you can sell only clear lumber there is a tremendous waste that must be left either at the sawmill or in the forest.

I want to say at the outset, without any thought of criticising nature, that nature would have been a great conservator of forest products if she had permitted trees to grow square rather than round, because the fact that the log had to be square was one of the reasons for great waste in those early days. There was no thought of making anything of slabs, and the slab burners of the country have been a great enemy of conservation. I do not know, nor does anyone know, how many billions, aye, countless billions, of good material have gone up in the form of heat and smoke through the slab burner, a perfectly innocent apparatus, so far as that is concerned. I attribute the loss. not to the apparatus itself, but to the market conditions. That part of the log was burned hecause there was no market for it, and the lumberman was compelled to make whatever the people would buy.

Now, the waste has gone on not only in pine and softwoods but in the hardwoods as well. I had some experience in the south as a lumberman in the manufacture of hardwood, and I am going to give you a brief review of what I saw there and of what is going on not only now, but as far back as the nineties. Prior to the entry of the sawmill in the southern forests, there had been a system of timber destruction going on in the South, particularly of the very choicest white oak, that I thought was a reflection upon this Government.

I arge crews of men in these southern forests were in the business of making what is known as pipe stares. The stares were 60 inches long and from 4 to 6 inches wide. and could be made only of the very best quality of white oak that had a perfectly straight grain. Whenever they found a tree with a winding grain they had to leave it. because they could not use a crooked stick. The syistem was this: They 
made arrangements with the owner, paying, as a rule, $\$ 2.00$ per tree, to cut any tree in the forest that was over 30 inches in diameter-I may say any white oak tree. 'They cut it, and cut off the first bolt. If it did not split perfectly straight, they went away and left the tree to rot in the forest. By that system no doubt billions of feet of splendid white oak were left to waste in the woods. Every sawmill today utilizes the tree up to the point where the large limbs appear, or as far into the top as you can possibly use it to make a board of any kind. Now, they took out of the forests of the South the most beautiful, the best, clear white oak, which today would be worth countless millions of dollars, and which they sold for $\$ 2.00$ a tree. I don't know what one would have to pay today if one went out to buy it.

Gum as far back as 1900 had practically no value. I started a sawmill in the Yazoo Delta in 1892. I sawed enough so-called red gum to build our plant and our tramways, and I sawed possibly 100,000 feet more than we actually needed. I though I could sell it. I could not gire it away. Finally I sold it to the planters for $\$ 1.00$ a load to get it out of the yard. 'The same may be said of white ash. 'There was a splendid growth of what was commonly known as cane ash. It was slaughtered for one purpose or another and was sold or practically given away. It was used largely for mechanical purposes and would be a raluable timber if we had it today.

'The history of hickory is rather interesting to the lumberman. I remember when southern hickory with the wide. broad, redheart, or what we lumbermen used to call shellbark hickory, had no value at all. Everybody wanted what was called second growth hickory from Indiana and Ohio. About 1900, people's notions changed in that regard, because the supply of hickory was about exhausted. 'They began to saw and use shellbark hickory; and about this time I imagine the market was glad to take eren that kind of hickory.

The poplar tree had the same history. As long as poplar was available you could not sell cottonwood at any price. I recall when so-called boxboards sold for \$12 per thousand f. o. b. Memphis. Standing cottonwood was worth 60 cents a thousand. The supply is exhausted. Cottonwood has gone. and now they have come to gum; and it is truly unfortunate that so many countless billion feet of gum, that beautiful. splendid tree, have gone to waste before we began to appreciate its value. The planters of the South destroyed it. They 
girdled it, left it standing for a year or two, and then set it on fire. It was in their way. The timbermen went by, fortunately, where the wood was still standing. The gum tree that was neglected back in the nineties is now being put to practical use and has direct commercial value. That was due to the fact that so much timber of a better quality was available during those years, and at a cheaper price, that the people refused to use the poorer qualities of timber at any price whatever.

It is unfortunate for the country and unfortunate for the timber supply of the country that there was not some control. even back in the sixties and seventies when the great timber supply was here; that there was not some supervision that compelled the use of what we at that time regarded as the class of timber that had no commercial value for purposes to which it could be put and save the high-grade timber- the timber that we need so much today-for the future. But somehow our forefathers did not foresee it. We will not blame them for it. It is not a nice thing to speak ill of those who went before us. We do not mean it that way, but we can express regret that no form of intelligent supervision was undertaken at that time. I am sure that many billions of dollars' worth of beautiful timber that was slaughtered for nothing might have been saved for the benefit of future generations.

We have reached the point now where we appreciate that. I believe that all thinking men appreciate the fact that the question of a timber supply for the future has resolved itself into a serious proposition. It is true that we are using now what we left in years gone by. We are using now eren the despised hemlock that you could not give away in the early days. Nobody would look at it. It was not good building material in the past. It may be the best we have now, but, compared with what we used to have. it is not good; nevertheless, we have to use it. That is becoming exhausted. however, little by little, and in the course of time the hemlock will be in the same situation that the cork pine was in, a magnificent supply when we started, but completely exhausted. Now, what shall we use as a substitute for hemlock? I do not know. We shall have to find some ornery tree that we would not use in the past and do not care for now, but it will answer the purpose and will look better when we need it. 
How much more could be said upon the question of the timber that has disappeared. Let us consider walnut, if you please, for a while. There was a time, as most of you know, several older people tell us and younger people have read it, that they built rail fences in Indiana and Ohio of walnut. Now they are digging out the stumps of what was left, veneering it for covering for pianos and beautiful furniture. The walnut $\log$ is about as scarce as a gold mine now. There is very little left indeed. There is a small supply left in Oklahoma that is so far away from transportation that one could not afford to handle it. White oak is becoming rery scarce. I had in my day a wide experience in the manufacture of white oak, and I felt that I was quite conversant with the supply throughout the United States. I made a study of it at that time. A man might offer me any price today that he chooses in asking me to furnish a sawmill where I could supply him with, say 100,000,000 feet of white oak in the next ten years; I should have to tell him frankly, I would not know where to go. By white oak I mean the kind that can be used for finish, the kind that we used to regard as merchantable white oak during the days when we actually had a supply.

Now there enters into this question the tie supply for railroads. There is still quite a lot of white oak available along the Ohio river, some in the mountains of Tennessee, some in the state of Mississippi; and as you go on through the South you will find a little patch of white oak here and there that the planter has refused to cut down because of some sentiment commected with it or because he wanted to keep it for ornamental purposes. You will find in Arkansas little patches and stands of timber that the lumberman has gone through which he left because the trees could not be used for ties and merchantable timber. Vast quantities of ties in this country are being made of hemlock and other softwoods, and the railroads are getting along with what years ago they thought they could not use. The hemlock is going and so are the other woods that they are using, and finally some other material must be substituted.

But to get at what I was asked to speak about. What are we going to do to better conserve our forests, our timber supply; and what kind of legislation should be enacted to do that? The people of this country are not agreed upon this subject. In fact, it is one of our peculiarities that we are never quite agreed upon any subject. 
and there was never greater evidence of that than now. However, this state has had some experience in reforesting. We have attempted, and we have made an honest attempt, to replant some of our cut-over timberlands. Now, I have this to say about it. As a state policy it is not a possible thing today.

The cost of the land, the cost of planting, the cost of the care that the plant needs, the taxes that the state loses provided it reserves this land for forestry purposes, make the price, if we compute it up to the time that the trees might have become merchantable, so high as to make it an impracticable thing. Nor is it, in my judgment, a state duty. Let us assume that the state of Wisconsin would plant in the northern part of our state a million acres of young pine. I do not know what it would cost to do it, nor does anyone else know. The best we could do is to make an estimate which would be liable to be wrong, but we would have to wait at least 50 years before we could get any merchantable timber. Now. when that timber comes into the market it is not for the state of $\mathrm{W}$ isconsin alone. If it were, it would not be a supply for the country, and what we need is a supply for the whole nation. So, then, those who agitate that the state ought to undertake reforestation would do it upon the basis that it is a state duty merely because we at one time had a forest, and that these states that at one time had forests should now undertake this great business proposition, this great speculative investment, in order that the whole country might have a timber supply. That does not appeal to me. It is not a state duty, it is a national duty. The national government should recognize it promptly and take hold of the future supply in an efficient manner. The timber supply of the future, the one which is produced, should be the supply of the entire country, and whatever it costs should be the expenditure of all of the people. There are many states in the Union that have never had any forests. Why should they come in on a timber supply that costs them nothing? No private citizen, I am sure, would like to invest his money in an enterprise that could not possibly, under the most favorable circumstances. give him any returns in less than 50 years. If we go into national production of hardwoods, why, we have to wait perhaps as much as 100 years.

In my experience as a lumberman I cut an oak tree in Mississippi that was 76 inches in diameter, 52 feet to the first limb. It had 
352 rings, and if we assume that each ring represents a year's growth, and no one has been willing to say that it represents any less than one year, then the minimum age of that tree was 352 years. That would have been a long time investment. So it would be with the hardwoods we plant; and it is not for the state of Wisconsin alone to wait, but the nation should wait. It can afford to because it is for the general good.

Now, I would recommend to Congress, if I were to recommend anything and they were willing to listen, that they provide for the purpose millions of acres of land, not merely cut-over lands, not merely land that produces perhaps scrubby timber. whatever kind it is, but some good agricultural land with it that will produce the hardwoods. We all know, who have had experience in the forest, that the oak and ash and the other hardwood timbers that we must have for mechanical purposes are not going to grow on a sand heap. They need good soil. The nation must sacrifice some good agricultural soil if it proposes to be a successful timber raiser. 'The government should provide the land and set it aside for that particular purpose. It should firmly stand against the demands of the agriculturist and say to the people that this land must be used for this particular purpose, that it is just as important to raise this crop as any other crop. It should be the rule in the future that whenever a tree is cut down a tree should be planted in its place, and that another tree be planted wherever there is room to produce one. And then we must look after the crop of trees. We must protect it against destruction by fire, against trespassers, etc.

Unless we go into the problem in an intelligent and practical way, of course, the whole project will be a failure. So then, those of us who are interested in the reproduction of the forest, and who appreciate that we must begin it now, ought to do our work not in the States, because I think it is useless, but go to the halls of Congress and impress Congress with the importance of this work.

The lumbermen of this country, perhaps, have the best conception of the value of timber and its fast disappearance. As an organization interested in replacing what they have cut down, interested in putting back the trees they have taken to the mill and sawed into lumber, they should go to Congress and impress Congress with the importance of the subject, in order to get the necessary appropriation and the nec- 
essary legislation to go into this question of reproducing our forests in an intelligent way. Lnless we do that we shall soon be out of timber.

Talk about reforesting the arid lands of the West! Now, fellow citizens, I do not know all about that, but it does seem to me that a section of the country or a land that nerer produced anything more than a little scrub sugar pine will never produce anything else. If the country must wait for that kind of timber culture. I am afraid we will find ourselves rery much out of lumber in the future. That type of land which does not produce anything left to itself. where nature has not planted the seed and produced it, that is not going to do anything under cultivation. It has no moisture, and there is nothing in the soil that will make it grow. It is so in our own state. We have sections here in Wisconsin that never raised good timber. There is nothing substantial in the soil to support the tree. It raises scrub stuff, scrub pine, Jack pine, and other pines of that rariety. You must wait 50 year's for that. So we must make up our minds that we must set aside soil that has substance enough in it to support a tree; otherwise we cannot have it.

I want to say in conclusion that I fully approve and have been in great sympathy with the work of the Forest Products Iaboratory. Its business has been to find new uses for timber that heretofore have not been considered satisfactory for any particular use. It has rendered a great service in that respect. It has also found many ways to use what was heretofore regarded as absolute waste around and about the sawmill. It was high time that somebody devoted some time to that, and in that respect whaterer they have accomplished has been of real use.

IVe must conserve, if you please, everything there is in a tree that can be used. You camnot throw away a six inch slab; you have got to make some use of it. They say of the packer that he makes use of every part of the hog excepting the squeal. We must make use of every part of the tree excepting the noise it makes when it falls. There must be a real spirit of conservation produced among our people; they should be able and willing to use ererything that is usable. 'The timber of today ought to be cut and used with reference to the use that it is to be put to. We should under no circumstances be permitted to use a good pine board. for instance, for a meat box that renders serv- 
ice but once and then goes into the furnace. That should no longer be permitted. Whether we can do that, whether we can regulate our lumber supply to that extent, I can not say, but it would be a right step towards conservation. You know what we really need sometimes is a king; we need a lumber king anyway, a man who could tell the people to do with what ther hare and compel them to do it. If we had that privilege we could conserve what we have.

I thank you for your time and I trust you will have a pleasant visit.

\section{Remarks by the Chairman, Mr. H. F. Weiss, Following. Governor Philipp's S pecch}

I renture to say that you gentlemen who are from our sister states wish you could have a Governor who understands the forestry program and problems as well as our Governor. That is just the way we do things in Wisconsin. (Applause.) Gorernor Philipp, I thank you for your splendid talk.

In connection with every business organization there are two words used which I have seldom, if erer, seen applied to an educational institution. They are "quality" and "service". You gentlemen who are engaged in business know full well to what I refer. The hours that rou have spent and are spending in improving the quality of your product and the splendid service which your company renders are things which you are interested in. If these terms were to be applied to an educational institution, I know of none which lay better claims to them than the University of Wisconsin. The high quality of the University's work is reflected not only in the faculty and its teachers, but in the great student body which it sends out every year. The high ideals of the University are not locked up in the text books nor in the class rooms, but in this State they reach out to the shop, to the factory, and to the legislature.

I think one of the biggest surprises of my life was when I first came to Wisconsin from my old home in New Jersey and saw farmers of fifty or more years of age walking down the streets of Madison with a text book under their arms, studying agriculture. This variety of farmer was totally unknown to me, and was not existent in the range bounded by the State of New Jersey. Through my years of 
living here it has been very evident to me why the Wisconsin farmer is able to make his farm pay while my old farmer friends in $\mathrm{New}$ Jersey are still paring for the mortgage on their farms.

I think the Forest Products Laboratory is particularly fortunate in being identified with such an institution as the Lniversity of Wisconsin, because it furnishes an inspiring example of not only how to gain knowledge, but, of what is of equally great importance, how to apply that knowledge.

It gires me great pleasure to present to you the man who stands at the head of this great seat of learning-President Birge. 


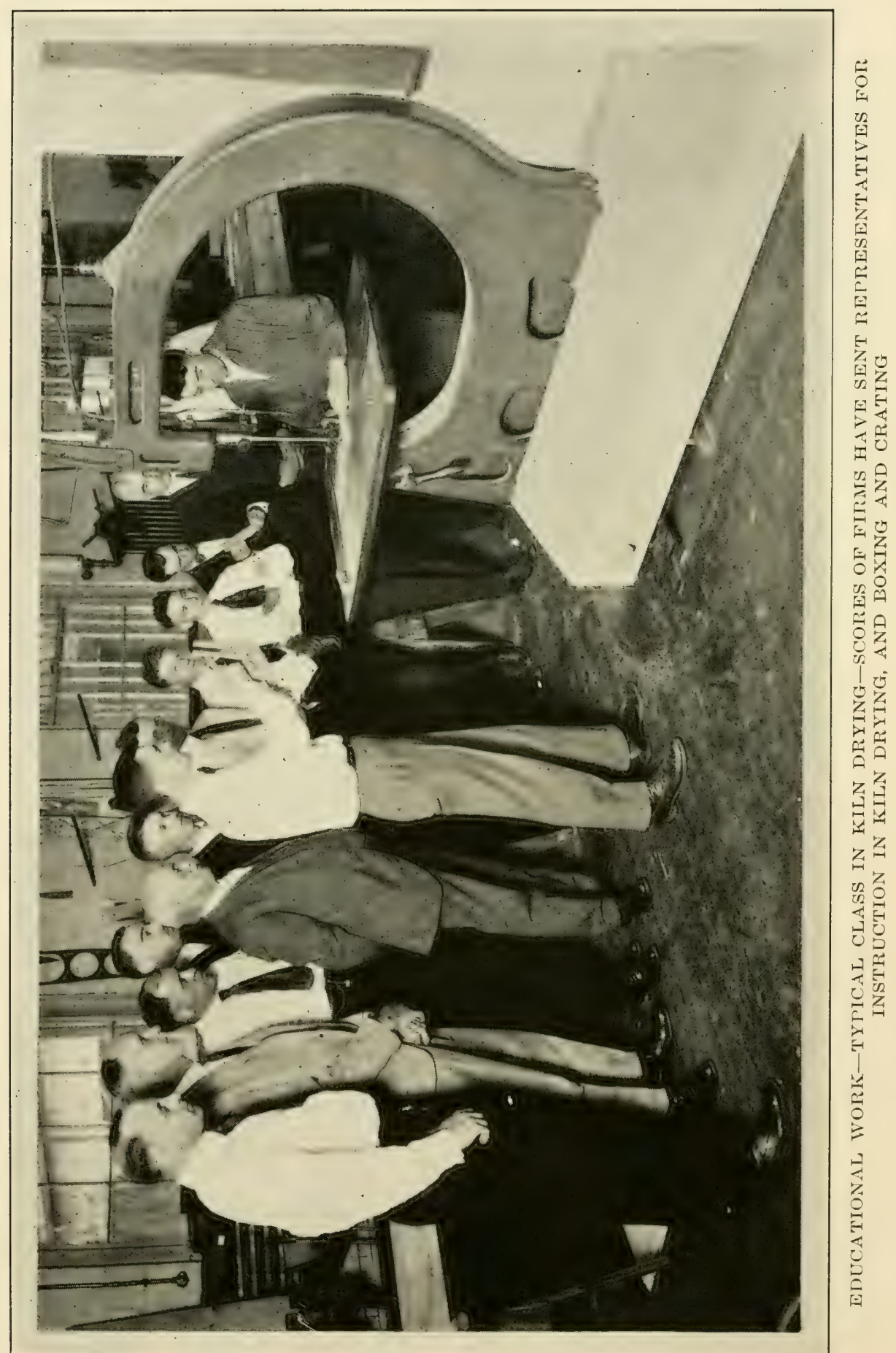




\section{TRANSTATING KNOULEDGE INTO POWER}

\section{E. A. Birge, President of the University of Wisconsin}

\section{Mr. Weiss and Members of this Convention:}

I suppose that I have been asked to speak here in two capacities. In the first place, I address you as a representative of the University, whose guests you are in some sense today, since you are meeting with us in the Unirersity ('ollege of Agriculture. We meet to celebrate the completion of the first ten years of the life of an institution which was established by the govermment of the Lnited States in cooperation with the State and the University of Wisconsin. It is an institution to whose prosperity and work this State has continued to make contributions, small. indeed almost negligible, in comparison to the total budget of the institution. negligible in comparison to that contribution of the United States gorernment. Nevertheless, they have been contributions which carried with them the hearty good will of the State and of the Iniversity. And we hope that we have also contributed something of the spiritual aid and fellowship which a university can give to an institution of research. We, ourselves, have received much from the presence of the laboratory with us. and we hope that we have heen able, in our turn. to give something to it. So I welcome you, as representing an institution of the type which ought to gather about universities, carrying on work of a kind which is represented within the university as well as in its ascociated institutions. I welcome you with especial warmth as you are present here to celebrate a decade of distinguished success in services and investigations so fundamental to the alvance of the science and art of forestry.

In the second place I am here to speak on the subject assigned to me by Mr. Weiss and Mr. Winslow-Transtating Kundedge Into Pozcer. You have just had a most rivid sketch of the history of the lumber resources of the country and of their present situation from Governor Philipp, who speaks to you not only from the point of view of a statesman, but also from the point of view of one who has spent. years in the industry that you represent. You will hear, after I have talked to you, a vivid presentation of the Forest Products I aboratory 
itself and its specific work from its director, $\mathrm{Mr}$. Winslow. So, if I interpret rightly the subject assigned to me, I am expected to sandwich, as it were, between these two vivid and interesting stories a little of what might perhaps be called "highbrow stuff", a little of that sort of talk which is supposed to belong to the traditional university.

When Governor Philipp was telling us the story of lumber, he spoke of the indifference of the last generation to the situation with which we are now confronted. It is easy for us now to see that our parents were blind to conditions which the future was sure to bring. I do not believe that we should criticize them too severely for this blindness, for I suppose that our descendants, fifty or a hundred years hence, will look back to us and will wonder at our blindness just as we wonder at the ignorance of our fore-fathers. Howerer blind they may have been, they were not without excuse. for the conditions under which they lived were wholly new in the history of the world. No preceding century ever saw a growth of population in the least comparable with that of the 19th century in Western Europe, and especially in our own country. And still more, no preceding century saw that rapid increase of drafts on natural resources which was characteristic of the 19th century, and especially of its later years. If, therefore, our fathers did not foresee the future. it was because the story of the past br which alone they could conjecture the conditions of the future, did not enable them to foresee them; and we ought, therefore, not to blame them for ignorance. We, howerer, are in a totally different position, and if we do not foresee and provide for the future it will not be because of ignorance, but because of indifference and slothfulness.

In our use of forest products we have been drawing on the balance of resources which has accumulated during the remote past. We can now see very plainly that in no long time this balance will be exhausted, and that if we draw a check on nature's bank, it will be returned to us promptly marked "No funds". The western world has never been in this situation before. It is a wholly new thing that a great people like ours should be face to face with the situation that it must depend for its supply of wood upon the annual growth. It is a new thing that a people should be placed in a position where the annual growth of timber will be the substantial limit of the amount which that people can use. 
This situation is not confined to the forest products. In all of those resources which are produced by the earth the same situation is arising or has already come to pass. We can not easily increase the area of productive land or of utilizable water. We must make the annual production of land and water suffice for our needs.

As this situation begins to become manifest, we take various measures in order to reduce the depletion of our balance in nature's bank; in order also to increase the annual production. We put up restrictions, both legal and moral. upon the use of the products of nature. We go still farther and endearor to increase the annual income of these productions. We set up fish hatcheries; we produce improved rarieties of seed so that the net increase of the land and water may be made larger and that there mar be a greater amount in this annual contribution of the earth to our support; we try to utilize waste or what we once regarded as waste; we handle the inaking of coke so that what were formerly waste products are utilized; we orerhaul the culm bank of the coal mine and we rework the tailings of other mines. In all these ways and in many more we attempt to check the depletion of our natural resources.

In the use of forest products we increase our balance, as the Gorernor has told us, by emploring kinds and rarieties and sizes of wood which only a few years ago were regarded as entirely worthless. All of these methods are necessary and right, and they all help to prolong the period during which the balance in nature's bank may be available to us. They aid also in increasing the annual supply of the products which nature is putting forth for our use; but, as the Gorernor's story showed us, these means are inadequate-inadequate in erery direction and particularly inadequate in securing a permanent supply of forest products.

This raises the particular point which I was asked to talk about: this morning. I an asked to call your attention to another great asset, another great resource of a civilized people. which is being used slightly and very imperfectly, which is continually accumulating: which is capable of very great use; out of which will come great saving and great addition to natural resources and a correspondingly great prolongation and adrancement of the prosperity of the people. I am speaking of the stock of scientific knowledge which has accumulated during, let us say, the past half or three-quarters of a century. 
Look back at the condition of science in that earlier period to which the Governor referred in his talk about the forests. We celebrated here in Wisconsin a few weeks ago the fiftieth annirersary of the Wisconsin Academy of Sciences, founded in 1870. We talked about the men who were the fathers of that Academy. 'There was Lapham, a surveyor of Milwaukee; there was Dr. Hoy, a busy physician, in wide practice at Racine. This was the type of man who first brought science to Wisconsin. Fifty years ago, science was mainly in the hands of people busily engaged in other matters; that was true all over this country. Science was a side issue for people whose work and thought were chiefly given to other things. Since that time the situation has changed completely. In those days there were single individuals working at the exploration of nature, many of them doing this as a task for leisure hours; today we have an army of people who are devoting all their time to the exploration of nature and are deriving their living from this work. 'Thus the knowledge hich these men and women are bringing together, the knowledge which they have been bringing together during the past generation, has been accumulating at a rate which one may almost call tremendous. We look with surprise at the rapid increase of population during the past half century; we look with eren greater surprise at the enormous increase of wealth during the same period. But neither of these facts is in any way conparable to the increase of scientific knowledge during tho same years. Here, then, is an enormous asset which has been growing rapidly, increasing indeed at a geometric rate, and of which by far the greater portion has accumulated during the memory of men here present. It is an asset whose increase is still going on at a rate which is constantly accelerated. 'To this asset there are contributing, not merely a few men, not merely a few great men. but the labors of hundreds of thousands of men, working each in his own field of exploration.

This, then, is a new situation in the history of the world. It has made necessary the development of a new type of profession. of a new type of institution. It has made necessary men and institutions who are to mediate between knowledge in this sense of the word and practical life, between scientific knowledge and affairs. This situation has brought about the establishment of institutions of various types and in various directions. Such are agricultural colleges and experiment 
stations; such are institutions like the Ynited States Bureau of Standards; and such, also, is this institution in whose honor we meet todaythe Forest Products Laboratory.

It is noteworthy that these institutions have dereloped to greater size and in greater number in those relations which have to do with the soil and its products. Here we find the largest number of men whose business it is to take the knowledge which has been accumulated by the explorer of nature and to bring it into direct relation with affairs and with human life.

Let me take an illustration from the activities of the department of agriculture and outside of the forestry service. Consider for a moment the student of soils. His work is dependent upon the knowledge which has been brought together in past years in the department of chemistry, both organic and inorganic; it depends also on knowledge which is embodied in the sciences of bacteriology, of botany, of zoologr; and in addition to these specific sciences he needs the principles which have been wrought out in physies and in many other departments. 'The definite work of the student of soils is the application of knowledge and of principles which have been wrought out elsewhere. 'These he takes and applies to the conditions found in the soil.

There are two points to be noted in regard to this work. In the first place scientific knowledge can not apply itself, nor can it be directly carried orer from laboratory to field. For the conditions under which this knowledge has been wrought out are widely different from those in which it is applied. 'The student in the laboratory makes his own conditions of experiment, and it is only as he is able to define and to limit the conditions of nature that he is able to secure the results for which he is seeking. But the student of soils must carry this knowledge over into the world of affairs, into the complex situation which nature offer's to us. Knowledge must be set to work under nature and therefore under conditions totally different from those of the laboratory. 'The material conditions of the soil must be considered, the intelligence of those who are working it, and especially the relation of cost and of profit to the processes which are set up. All of these innumerable items which the scientific explorer neglects, and ought to neglect, must be carefully considered by those who are applying knowledge, since they furnish the conditions under which knowl- 
edge must be set to work, if it is to produce results that are useful to the people.

So it is with the Forest Products Laboratory. It is founded to bridge over the gap which lies between experiment and manufacturer; it must bridge the gap between laboratory and factory; in a word. it must bridge over the great gap which lies between knowledge and life, between knowledge and affairs. And this is not all; for it is not a simple matter to set knowledge at work under the conditions of nature. The representative of applied science does not merely take knowledge wrought out by others and put it to work under new conditions. The knowledge which is present as science is not stated in the form in which it can be used, since the statement does not take into account the complex conditions under which it is to be set to work. The representative of applied science, therefore, does not merely apply knowledge to new conditions but he translates that knowledge into those new forms in which alone it can be applied.

Thus the subject assigned to me is justified. The function of an institution like the Forest Products Laboratory is primarily the translation of knowledge into new terms and into such forms that it can be set to practical work in affairs. Such a translation involves not merely a knowledge of what other people have found out, but involves also scientific study and research itself. It involves, therefore, not merely an application of old knowledge but the derelopment of a new sort of knowledge; the development of knowledge which will work under conditions which are set not only by the tangled web of nature within which it is working, but also by the commercial and social conditions of the men on whom the practical success of applied science must depend.

Thus, as you see, out of the enormous increase of knowledge on the one side, out of the need for its application on the other side, there have arisen professions like those which are represented here today, and finally institutions like the Forest Products Laboratory. in which these professions find a home and an opportunity for service.

I will not trouble you with many illustrations. I et me take one or two from the work of the laboratory. It is necessary to find new types of wood and new forms of wood if airplanes are to be quickly and economically constructed. Hence there arises a need for waterproof glue. It would seem at first that such a need could be easily 
satisfied. We have only to go into the market and purchase what is offered. But as a matter of fact if such an adhesive is to be developed it will only be after scientific study and research which will bring in the accumulated knowledge from half a dozen sciences, and the men who make that research will need high scientific qualifications on their own part. Only thus can a produce be discovered which is worthy to put before the people and a product on which the people of the country can depend.

Or take another problem which arises not only in connection with the manufacture of airplanes but in a hundred directions involving the utilization of wood-the matter of kiln-drying. It seems at first a very easy thing to put wood into a kiln and dry it artificially. Yet you know better than I that the man who goes to work on that principle will rather spoil wood than produce good lumber. It is only as the complex conditions and problems involved in kiln-drying are appreciated and thoroughly mastered that success is reached. Only as there are scientifically worked out processes by which the different varieties of wood may be treated, each according to its own kind and condition, can success be secured, even in a process which looks at first so simple. And if in such matters as these, which seem to be simple. scientific study and scientific organization are necessary, much more is the same necessity present in the far more complex problems which are involved in the production of paper pulp, in the prevention of decay of timber, in the other infinitely varied uses to which timber is put.

I need not give you more illustrations, for these are enough to illustrate the principle which underlies the subject assigned to methe need of institutions like the Forest Products Laboratory, which shall concern themselves with the translation of knowledge into power and so shall make arailable for the benefit of the public along specific lines the enormously valuable asset which the world possesses in the accumulated treasures of science.

This necessity the government is trying to meet along one line through the Forest Products I aboratory an institution which mediates between knowledge and affairs. I congratulate the laboratory on the way it has performed this duty during the past ten years; I congratulate it for the work which it has done itself; I congratulate it as a part of the great working force of the Department of Agriculture; I congratulate it especially on the part which it has taken here 
in Wisconsin for our benefit as well as for the benefit of other states, on the part which it has taken in the work which our University on its side is trying to do, not only for its own state, but as a part of the national system of education.

But I can not confine what I have to say to a review of the past ten years. Let us look to the future, first looking back to an earlier day. Look back, if you please, to 1876, when the Lnited States celebrated its first centennial. How did we look at the forest resources of $\mathrm{W}$ isconsin at that time? Now look forward to the next centennial in 1976 and tell me what will be the situation then and what the necessity for institutions like the Forest Products Laboratory? We need not indeed look backward and forward so far. Took back less than twenty-five years to the state semi-centennial in 1898 and look forward to the centennial of the state. How have our forests disappeared in less than a quarter of a century; what will be their condition less than thirty years from now, in 1948, in a year when the large majority of those who are here this morning will take part in the centemnial celebration of the state? Upon what will the prosperity of this state depend at a period so short a time ahead of us as thirty years? Will it not be dependent upon the greatly enlarged work and success of institutions--of the Forest Products Laboratory and of other institutions akin to it; and upon the intelligent and vigorous utilization, by the people, of the results that they work out? The scientific knowledge which has accumulated in the past. and which will accumulate with even greater rapidity during the coming years, must be translated into terms of power by men who make it their profession so to treat knowledge and by institutions which are established for the purpose of setting knowledge to work in affairs. This they must not do in any rule-of-thumb way, not by means of prescriptive rules; but they must convert knowledge into the living and growing contribution of the human mind to the prosperity of the human race; they must translate the knowledge gained by the explorer of nature into the power of applied science.

\section{Remarks by Mr. Weiss Following President Birge's Speech}

I hope very much that those of you who have come from out of the city may find it possible to stay in Madison long enough to look 
also into the work of the University of Wisconsin and to see for yourselves the way in which the university has been translating its knowlerlge into power along the lines which President Birge has so kindly pointed out to us in his rery interesting talk. I do not believe his talk was at all too "highbrow" for the friends of the laboratory, as I am personally acquainted with many of them and know they ean grasp it and digest it. I thank you, President Birge.

WV now come to what I might call the third layer of this sandwich, as P'resident Birge has pointed it out. and it has been somewhat of a problem for me to know what to say in the way of presenting him. He does not need any introduction. I have not been able to talk about his work or his institution because he is going to do that; and I camnot talk about him personally hecause I know him too well for that, and. furthermore, it would be rather unfair for me to take adrantage of his natural modesty. So, after thinking it over, I have decided I would follow the adrice I once saw written on the blackboard of our laboratory. It said, "When in (leep water keep your mouth shut."

I am now going to state that we will have the pleasure of listening to the man who has worked so loyally and ably to make the Forest Products I aboratory the institution you will see today, and, of course. that refer's to none other than C. P'. Winslow, best known to all his personal friends as "Cap". 


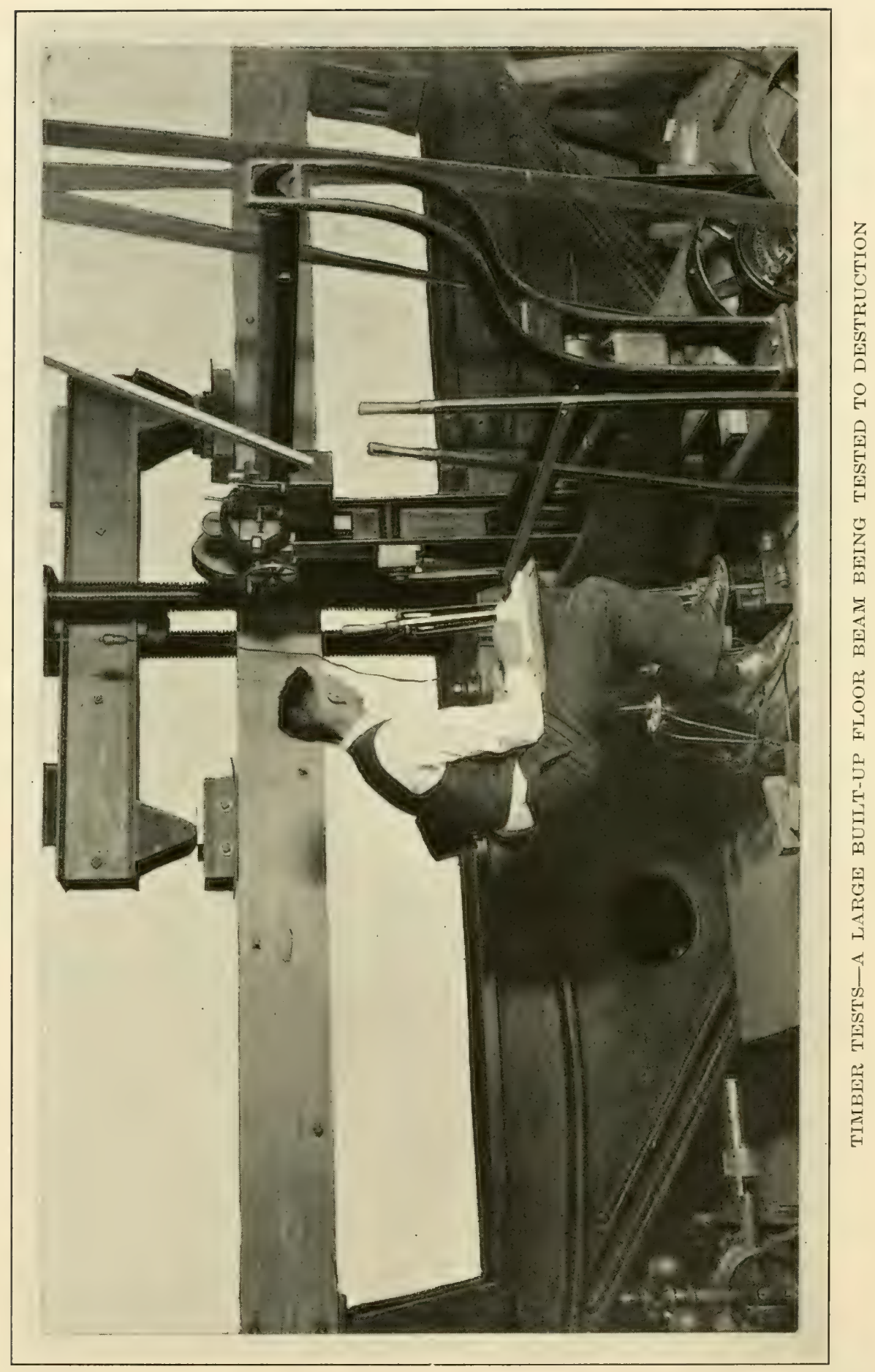




\section{THE FOREST PRODI'TS LABORATORY}

\section{Carlile P. Winslow, Director, Forest Products Laboratory}

Mr. Chairman, Ladies and Gentlemen:

It affords me a great deal of pleasure-more than I can really well express to you-to extend to you a most cordial and hearty welcome to this commemoration of the completion of the first ten-year period of serrice of the Forest Products Laboratory. I wish particularly- to express my appreciation of the work and efforts of the Decennial Committee which has planned and arranged for this erent, to those f'riends and supporters of the laboratory who by their generous contributions lave made it possible, and to all of you here who are thus lending your support and encouragement to the organization.

I am particularly appreciative of the untiring and effective efforts of the Chairman of the Committee. Mr. Howard F. Weiss, known to all of you in previous dars while Director of the Laboratory. andi I can only regret that Mr. MicGarrey Cline, the first Director of the organization. has found it impossible so to arrange his plans that he could also be here. It was my good fortune to work first under the stimulating guidance of these men when the Forest Products Laboratory was but a thought. and it is due to their imagination, foresight, and persistence that the laboratory was conceived, organized and put upon an effective working basis.

Rudyard Kipling once wrote:

"Twelve hundred million men are spread

About this Earth, and I and you

Wonder, when you and I are dead,

What will those luckless millions do?"

If we change the closing lines of this stanza to read:

"and I and you,

Wonder, when all the trees are gone,

What will those luckless millions do?" 
the kindly sarcasm of the Kipling humor disappears, and we are confronted with a question of vast importance for our consideration and action.

The importance of the broad problem would possibly be more sharply recognized if we view the situation from a somewhat less altruistic and international standpoint and consider only the 100 million people within the borders of the United States. Consider for a moment the extent to which forest products enter into the comforts, conveniences and pleasures of many, if not all, of this vast multitude of people. You rise in the morning from your wooden bed and walk about on the wooden floor of your wooden home; you bathe with soap probably containing or produced in part with a product from wood, annoint your face with a lotion containing alcohol very likely produced from wood paste, put on your hose manufactured from wood fibre, step into your leather shoes requiring tannin from wood for their manufacture, and then proceed to breakfast where you sit upon a wooden chair, in front of a wooden table and read the daily news from a paper made of wood pulp. printed with ink manufactured from a forest product, and receired orer telegraph lines supported by wooden poles. If reasonably prosperous. you now journey to your office in an automobile with wooden spokes in the wheels, probably travel at least part of the way over a wooden parement and finally settle yourself in your office surrounded by wooden trimmings and furniture and dig into the daily letters and reports which are again dependent upon the supply of wood pulp paper. If, by chance. you have occasion to travel to Madison to attend the celebration of the Forest Products Laboratory you board a wooden railroad car (or at least one made to appear like wood) and travel orer tracks supporter by wooden cross-ties. 'The food which you eat, the clothes which you wear, the materials and supplies necessary for the comforts of your home and the conduct of your business, all are received in containers, some of wood and some of fibre but practically all of forest products.

'These accustomed comforts and privileges of existence are dependent upon a very wide variety of industries, dependent to greater or less degree upon forest products. These supply useful and necessary occupation to some million or more people. They include twenty per cent of the 276,000 manufacturing plants in the country. 
The future of these varied and tremendous industries is dependent upon a supply of raw material - their ultimate and greatest success dependent upon the wise selection and most efficient handling of this raw material. This means that authentic knowledge of the properties of the material and how to most efficiently utilize them is, in the long run, essential to their continuation on a sound economic basis.

These considerations inevitably lead us to the forests. and here again we are confronted with a demand and necessity for knowledge of the properties and possible uses and utilization of the many available species. Without it, it is impossible to know which trees to cut or which to grow, what is their value, how best to utilize them, or what to do with the enormous quantity of waste material.

It was such broad conceptions as these that led to the development of the Forest Products Laboratory which was established in $1910 \mathrm{by}$ the Forest Service, United States Department of Agriculture, in cooperation with the University of Wisconsin. Federal appropriations maintain the organization and provide necessary supplies and equipment. The University provides the buildings and light, heat and power, at least within certain limitations. It is a pleasure to be able here to express to the President, Board of Regents and members of the Cniversity Faculty my appreciation of the whole-hearted and effective cooperation which has been so generously extended to the laboratory throughout its existence. This was of particualar value and importance during the war emergency period, when the expansions in our organization made it necessary to utilize in part or in whole some eight additional University buildings. I wish to make particular acknowledgment to the College of Agriculture, whose buildings were not only largely used by our organization during the war but sereral of which are still in use for this purpose.

The Forest Products Laboratory is called an institution of industrial research. Its object is to acquire, disseminate and apply useful knowledge of the properties, uses, and methods of utilization of all forest products. This is a broad field of almost unlimited scope-the surface has, as yet, been but partially scratehed.

It has been said that research is primarily a matter of men "who work upon the frontiers of knowledge, conquering new domains". Research may be done-as a matter of fact is done-individually, separately, disconnectedly, and progress of some sort will, undoubtedly, 
result. But to organize, correlate, co-ordinate and direct such effort must, in the long run, bring greater progress, in less time, with less expense, and greater saving.

This has been the guiding thought in the derelopment of the Forest Products Laboratory-the syrstematic acquiring of useful knowledge that may be transformed into the power that builds up American industries. With the exception of a similar and much smaller institution in Canada, it is the only institution of its sort in existence. However, the importance of such work is becoming generally and, in fact, internationally recognized. 'The Australian government now has under way the derelopment of a forest products laboratory and similar developments are under way by the British government in India, and, to a very limited extent, in South Africa. Former members of our staff have, within the year, left to take up such work in these countries. Norway also has similar plans under development although they have not, as yet, progressed as far as in Australia and India.

Work of this character requires the services of highly trained specialists along widely rarying lines. The forester's knowledge of tree growth is necessary to the engineer studying the mechanical properties of various trees in order that he may wisely select for study those species which are or may become arailable for use; the engineer's knowledge is necessary to the physicist engaged in problems of drying wood in order that the effect of such treatment on the mechanical properties may not be overlooked; the pathologist's knowledge is necessary both to the engineer and physicist in order to determine the effect of decay on the properties under investigation and equally is his knowledge necessary to the chemist pursuing his work on the development of durable water-resistant glues, on preservatives to prevent decay. and on prevention of decay in pulpwood and wood pulp. The knowledge of the dendrologist is necessary to all in order that the identity of the species under study may be determined with certainty and in order that peculiarities of their structural anatomy may not be overlooked.

An organization of such men provided with proper equipment, materials and facilities for work cannot. in the long run, fail to secure results of ralue. It is such an organization that we have attempted to develop here. I shall make no attempt, at this time, to describe it 
in further detail. You will, this afternoon, get a first hand comprehensive idea of its present scope. Suffice it to say that prior to 1917 it composed a persomel of approximately 80, expanding during the next 18 months to 500 and at present including slightly less than half that number. 'The aggregate expenditures orer the entire ten-year' period are in the neighborhood of two million dollars a yearly arerage of about $\$ 200,000$. 'This is but an insignificant sum when the breadth of the field and mangitude of the problems are considered. 'The results of much of the work camnot, of course, be quoted in dollars and cents. Certain other results. however. enable the use of such a yard measure, and a few of them will. I am sure. serve to convince you that organized industrial research is a paying proposition.

For example: 'The building and construction trade uses ammually approximately five and one-half billion feet for structural purposes where strength is important. 'This material is worth roughly $\$ 200,000,000$. Investigations at the Forest Products Taboratory on the mechanical properties of American woods have given knowledge permitting a twenty per cent increase in allowable working stresses in many structural timbers. If the results are actually applied to only ten per cent of such material. the anmual saving will equal $\$ \$, 000,000$.

'The claims for loss and damage to commodities in shipment actually paid by the railroads amount to $\$ 100.000,000$ ammually. Proper nailing. developed and recommended by the Forest Products I aboratory, and adopted by the National Association of Box Manufacturers, and through them hy many companies and shippers. if conservatively estimated to save lut one per cent of this loss. means a total saving of $\$ 1,000,000$ a year.

Work on water-resistant glues and plywood for airplanes carried on at the laboratory during the war emergency alone saved the War Department $\$(6,000.000$ in their procurement of such material during a twelve months period.

Investigations carried on at the laboratory during the past year regarding the use of hull fiber and second cut cotton linters for pulp and paper have made available 200.000 tons for this purpose and have resulted in the establishment of large plants with potential production of 300 tons per day and an annual sales value of $\$ 15.000,000$. 
Improved methods of turpentining dereloped by the Forest Service resulted in increased yields and less injury to timber with net savings aggregating $\$ 4,000,000$ per year.

These few examples alone show combined annual increase in production and decrease in waste aggregating $\$ 30,000,000$. They should serve to crystallize for you the value and importance of industrial research. Results. of course, cannot be obtained orer night. Patience is required and efforts are not always quickly crowned with success - but it cannot be doubted that over any reasonable period of years, economies resulting from organized research so greatly exceed the expense involved that there can be no question of its desirability.

The lumber and wood-ussing industries represent some of the greatest and most important manufacturing and industrial developments of the country. Of the nation's industries they rank second in invested capital. first in labor employed, and second in annual value of products. The Forest Products Laboratory is the only institution of organized research engaged upon the problems of these industries, and those problems yet untouched and unexplored are many and of far reaching importance. What, for example, of the possibilities which may result from the development of permanently durable and waterproof glues or adhesives and their application to the use of material too small or of too poor a grade for other service-what of their application to forest economies through the increased value thus given to small second growth material? What of the sulphite-pulp liquor problem involving the possibility of utilizing the $5 \tilde{5}$ per cent of the wood fed into the pulp digesters and now lost in the waste sulphite licuors? What of the problems of packing, boxing, and crating of rarious materials and commodities for shipment and transportation when conservative estimates show a possible theoretical annual saving to the country of three hundred million dollars? What of the need for improvement and the method of treatment and handling of piling and dock timbers in water infested with marine borers which destroy the piling within 18 months after placement and cause an annual replacement aggregating millions of dollars in the various harbors of the nation? What of the waning supply of hardwoods and the need for authentic knowledge of the properties of South American and other foreign woods as compared to those of our own country for which they may ultimately be needed as substitutes? 
Slight progress and success applied to only a small per cent of even the limited field above suggested, will result in annual savings greater than the total expenses for the entire Forest Products Laboratory for the past ten-year period. Such sarings. of course. will not result only from research within the confines of the laboratory; but will necessitate the dissemination and application of these results in industrial service. Your help is particularly needed in this phase of the work. 


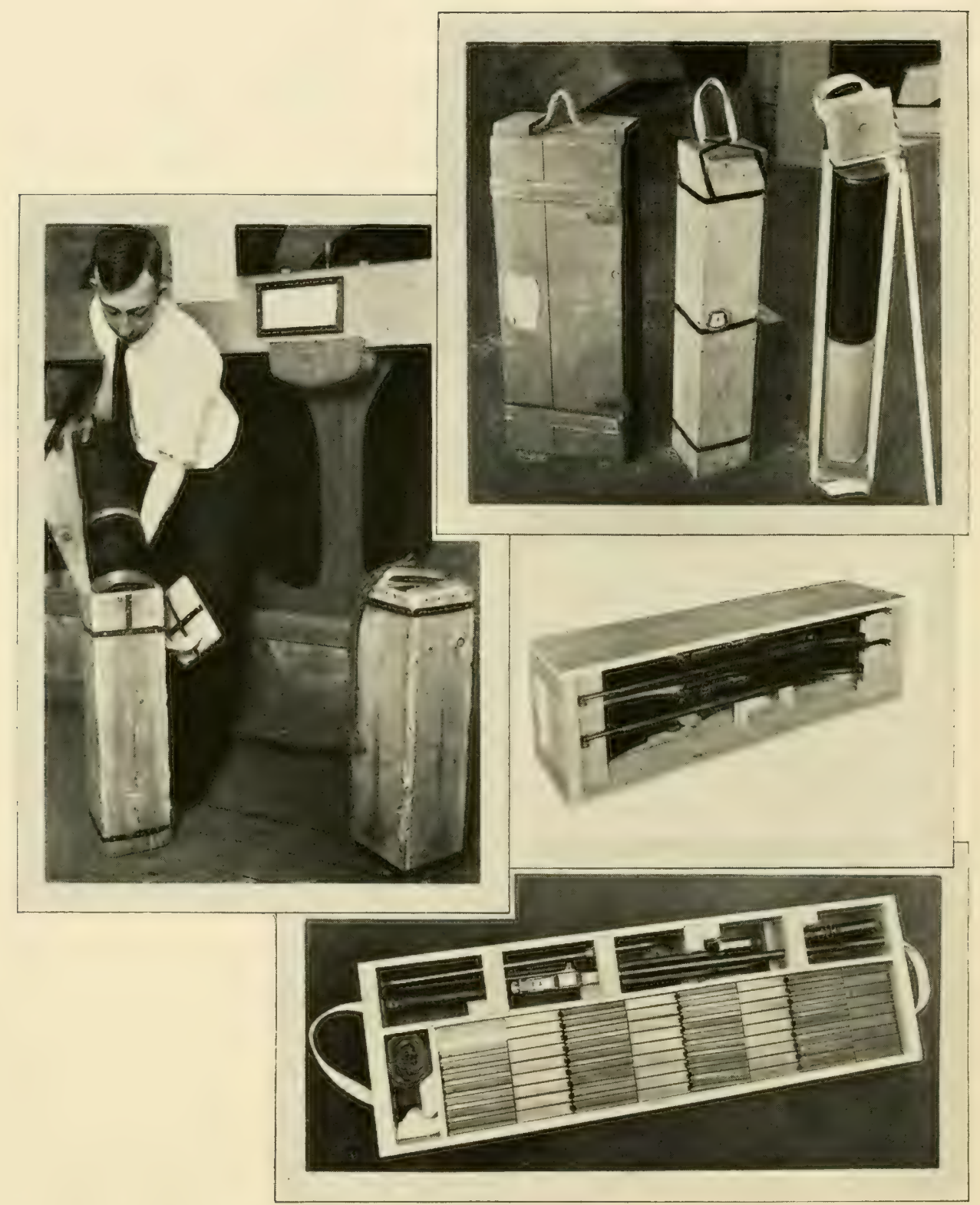

NEW BOXES FOR OLD-SOME WAR TIME BOX WORK OF THE LABORATORY Trench Mortar Shell Boxes

4.7 Inch Shell Boxes

U. S. Army Rifles Box

Browning Automatic Rifles Box 


\section{IN'TRODUC'TORY SPEECH}

\section{Burr W. Jones, T'oastmaster}

You had an opportunity today to witness an exhibition such as you would not find any other place on the face of the globe. It is true that several people have imitations of our laboratory. 'Ther have one in Canada; they have one in Australia; Great Britain has started two or three in far off' India and If rica; but none of them can offer such an exhibition or compare with such an exhibit as you have seen today. 'This was the original Forest Products I aboratory. For some time it was the only one.

It had a rery modest begimning-several gentlemen worked here in two or three rooms out in Wingra Park. 'They corresponded with some others in other parts of the country. Some of the wise men in Washington-there are always a few wise men in Washington-became interested, and our Board of Regents, who were always progressive, became interested; and it was finally arranged, as you heard today, that the Regents would erect a building and that the government at Wrashington would fumish the money to maintain it. So the work went on.

We here in Maclison did not hear very much about it until we got into the war, and then we hegan to hear a good deal. We used to hear that the government had recognized its child and appreciated the great service which the Forests Products I aboratory could render. 'They had a comparatively small number of men on the force, but during the war they had five or six hundred. Instead of one building which they harl occupied they then occupied the most of nine or ten, and they were aiding the government in many ways.

I suppose that the human mind can hardly conceive of the rast amount of shipping which it was necessary for our government to begin to send orer the seas. I can hest illustrate it perhaps by the incident of the boy who was told by his teacher to find out from his father what a million dollars meant. The boy went to his father and asked him. 'The father was rather amused and interested at the precocity of his boy and answered, not very prudently, "A million dol- 
lars! A million dollars is a hell of a lot." The boy gave his teacher this valuable information in the language of his father, and the boy got a licking.

Now this illustrates in a way, in somewhat emphatic language it describes, the vast amount of material which our government had to send across the seas. They came to this laboratory for advice. I suppose that those who originated the idea never dreamed that this institution out here would be aiding our great government, in a war with the great nation of Germany, to send beyond the seas such articles as munitions, rifles, and all kinds of accessories of war. Y't, such was the fact. At this time we began to hear about the work of the laboratory. We began to hear, and have heard ever since, that while it has been in existence, hundreds of men have come here. Several hundred men from the great industries have come to take their short courses of instruction. Such companies in the United States as the General Electric, the Western Electric, and many others of the great corporations have sent their representatives here to learn something which would aid them in carrying on their practical work. The liberal representation of lumbermen. those interested in manufactures, here today illustrates their view of the importance of this work.

I listened today to Dr. Birge and Governor Philipp, and I heard Mr. Winslow talk a little about the work which had been done here. I talked a little with him before, and I talked with Mr. Weiss. and it seems to me that they are the two most modest fellows I ever saw. Why, as Mr. Winslow made his speech today, telling in his morlest. quiet way of the work of this institution, if he had been followed by one of those orators (properly coached. and told what ought to be said), one of the orators from the Chicago Convention - the Republican Convention - or the San Francisco Democratic Convention, with his foghorn roice and his swinging arms, I don't know what we might have done. We might have gathered in processions and wrapped the flag around Mr. Weiss, Mr. Winslow, Gorernor Philipp and President Birge, but it has not been the method of the laboratory to indulge in that kind of publicity.

Now we are going to hear from a gentleman presently who knows not only about the work of this institution, but about forestry in general. When I was a lad living on the old farm I mistrust that if anyone said to a group of farmers that it would be a good thing to send 
fellows to a college to learn about forestry he would have been ridiculed. They would all have felt that there was no need of sending a man to college to learn to split rails, or cut saw-logs; but we have one here tonight, a real forester, who has been in college, and the account that I may give of him sounds like a fairy tale-reared in California, educated at the State Lniversity, then at Yale, he first took control of forest matters in the Appalachians, was then called back to the Sequoia forest, then to the great forests of Montana and Idaho, then to Washington, and like so many of our other patriotic college men, he was called to France. First he was called upon to aid in reeruiting twenty thousand foresters. I imagine when Alexander, Caesar, and Bonaparte carried on their wars they did not recruit foresters, but this gentleman who is to talk tonight did. He went over to France, and there in the forests of France he ran sawmills and he ran the lumberjacks, and helped win the war. He came back and is now connected with the goremment forestry service, the Chief of the Forest Service. I take great pleasure in introducing Colonel Greeley. 


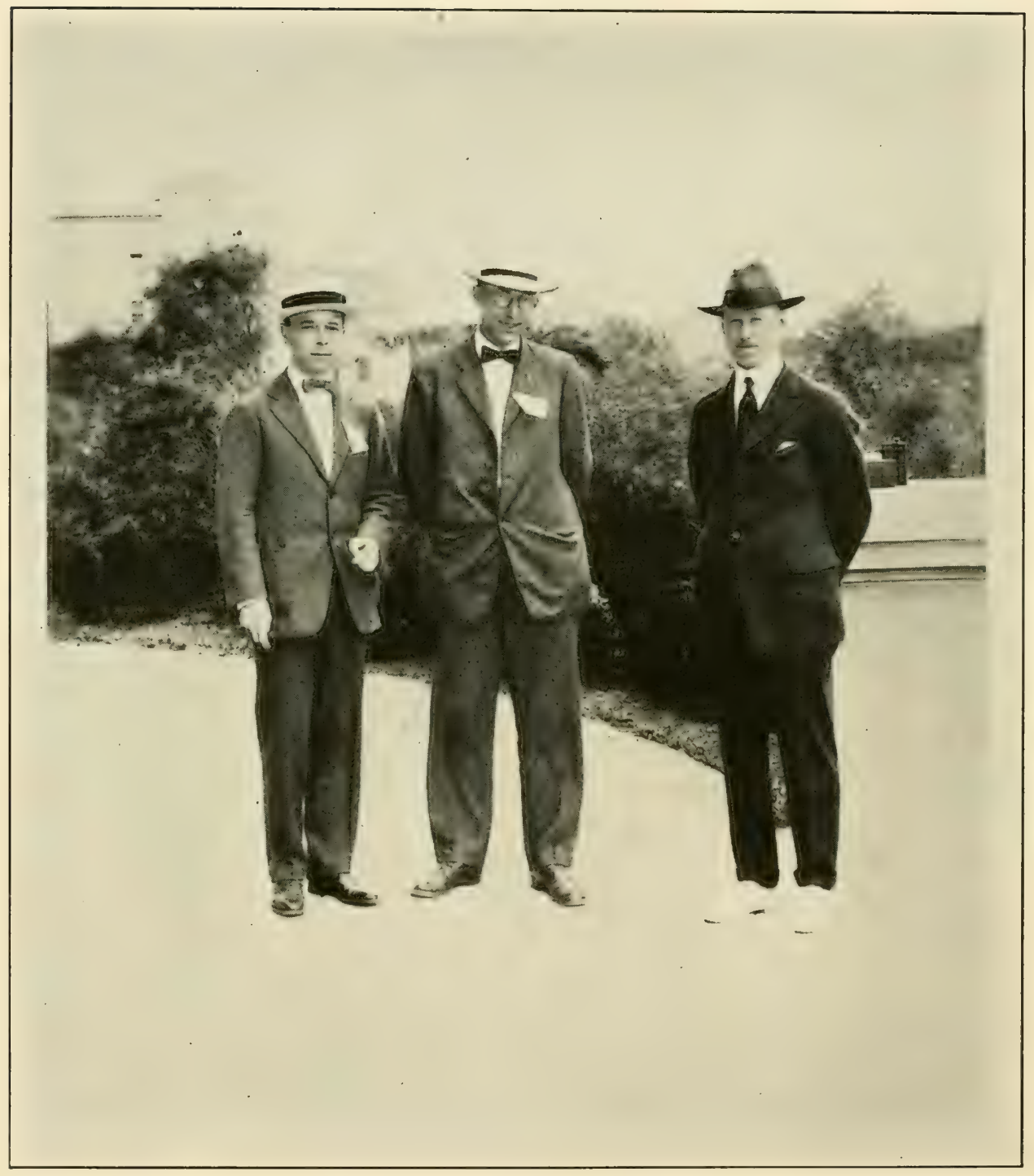

NOTABLE DECENNIAL FIGURES

DIRECTOR C. P. WINSLOW, FORESTER W. B. GREELEY, FORMER DIRECTOR H. F. WVISS 


\section{FORESTS ANI) NA'TIONAL PROSPERITY}

\section{William B. Grecley, Forester, U.S. Forest Service}

This morning when I entered the hotel and approached the gentleman in charge of the check rooms he pointed to a group of gentlemen in the lobby wearing this little white ribbon and said, "Be this the undertakers" convention!" I said, "No, sir, this is a convention of woodusers." 'Then, "Well, them undertakers use lots of wood." So I think Mr. Winslow should have capped the climax by referring to the wooden coffin in which most of us hope to repose our weary hones after the game has been played to the last goal.

Someone has suggested to me that I am supposed to make a keynote speech tonight. I know that keynote speeches are popular pastime this summer, but I want to assure you that I have no kernote ambitions. In fact. judging from the experience that I have just come from-I think the rery last speech I made prior to this-- I come to you in a very humble frame of mind. I was talking to a group of ranchers, road builders, ete. out on one of our Colorado forests. IVe were talking about timber, the resources of that region, and I got up hefore them with a good deal of enthusiasm and talked about what the Forest Service was going to do, what we were going to do with our timber. with our water power. our grazing lands, etc., and really, I suppose gave the impression that I possibly was the sole owner and dictator of this rast public domain. Well, after the ceremonies were over one of the old-timers, a man who had grown up in that country since early boyhood, in the audience approached me. The "my" and "our" in my speech had not set just right on the old man's srstem. He said. "Young fellow, your talk sounded to me a little bit like the time when the devil took our I ord and Master up on high mountain and showed him all the domains of the world and said that all of those should he his if he would only do what Mr. Devil said, and the durned old coot did not own a single acre of it."

There is no occasion for kernote speeches. The things that have brought us together are the simple fundamental things and the sort of 
things that we should approach in the light of sober, every-day, wellknown truth.

These are days when the whole world is being reconstructed. The stage is set for a new era in international relations and industrial competition. The times make it worth while to consider some of the things which in the new rivalry of world progress will make nations strong. We hear much about the oil fields of the world and how the industrial control of the harrassed old planet will lie with the people who control the bulk of its crude oil. Yet, oil is but an example of the many raw materials which modern civilization demands. And while keeping a watchful eye upon new and undeveloped sources of raw material. surely we must not overlook the resources which nature has put in our own hands.

Many of us who served in France were able to see at first hand the conditions of life and industry in a country where population has crowded close upon natural resources, where for the masses living has become close and hard, and, even to maintain standards of comfort far below what the arerage American demands, a degree of thrift and frugality beyond our comprehension must be constantly employed. In France wood is a commodity of a totally different character from what it has been in the United States. Fren with the care and intelligence applied unremittingly to French forests, lumber is priced as an imported luxury. No one can become familiar with that country without appreciating how this fact handicaps the comfort of living and the industrial opportunities of the French nation. The gleaning of the forests for little fagots, the very scaffolds used in city building. which are made out of small poles carefully lashed together and used orer and orer again, tell the story. With all their beauty and picturesqueness. the rural districts of France often leave an impression of decadence. A new structure of any kind is a rare sight and moss-corered stone buildings of the time of Jeanne d'Arc must serve the French farmer of todar. Only a people great in industry and foresight could, under such limitations, hare built up within an area less than that of our single largest state, the great industrial nation that France is today.

The lesson which such things bring home is, in a broad way, the same fundamental truth which underlies many economic problems of 
the present time-not alone those of America, but of the whole world as it strives to get back to normal industry. It is an old and simple axiom: Aside from the will to work which is the foremost quality of any strong nation, its economic and social progress depends in the long run upon the foresight and efficiency with which its natural resources are used.

This is simply an attempt to restate, crudely and partially, the conception of national conservation which was embodied in our public thought and policies by President Rooserelt fifteen years ago. It is the viewpoint of the public welware in the long run which two great leaders, President Roosevelt and Gifford Pinchot, brought to bear upon our forest resources, our national water powers, and our national deposits of coal and oil. The Forest Products Laboratory at Madison, which now completes its first decade, stands as a visible and practical expression of the thought of these leaders in the field of forest conservation. To make the most of our forest resources Mr. Pinchot and his associates foresaw that knowledge of the use of wood must progress hand in hand with the national movement to assure a sufficient supply of this essential raw material. Each had an integral part in forest conservation. It was not enough to create National Forests in which the Federal Government might embark in the business of timber production and to assist the private owner in keeping his woodlands productive. It was equally necessary to build up a practical science of wood use,- to determine how to get the right stick into the right place where its strength or durability would count for the most; how to make one railroad tie do the work of two or three. by prolonging its life and service; how to utilize the enormous quantities of waste material in our forests and sawmills; how to reduce manufacturing losses and better the methods of employing wood in the infinite number of American industries which require it, from the paper mill to the automobile factory; and what fresh supplies of wood could be found for this or that industry as old sources of raw material were exhausted. The Forest Products Laboratory was built by men who saw that to answer these questions and others like them was as necessary as to stop forest fires; that the wood technician in the factory must supplement the woodsman in the forest. And they not only built the Laboratory as an efficient unit of itself; they built it into and made it part of one of the most virile and far-sighted movements toward using nat- 
ural resources for national efficiency in the long rum that the world has ever witnessed.

Much in the way of practical forest conservation has been accomplished by this vigorous and growing movement. One hundred and fifty-five million acres of National Forests have been established and partially developed for the maximum public service in producing timber and forage and protecting water sources. Some thirty of the states have enlisted in the suppression of forest fires, and in spreading the gospel of wise use of timber-growing land. Much has been done in our industries to prolong the life of wood and utilize materials previously wasted. And yet we must recognize today that forestry is still just what President Roosevelt called it fifteen years ago-one of the most important internal problems of the United States. The aftermath of the war has indeed brought home its magnitude and its seriousness much more sharply than any previous event in the history of this country.

Consider for a moment our situation today as a people of wood users. The United States at this moment is short at least one million homes. In comparison with the need, new dwellings are being constructed at a snail's pace because of the high cost of lumber, other building materials, and of labor. From the shortage of homes arise exorbitant rents, crowded living conditions, and lowered standards of comfort and family life. The average farm in the I'nited States needs about two thousand board feet of lumber everyear for new buildings and improvements. Because the average farmer can not obtain lumber at prices within his reach, farm development is handicapped and the efficiency of agriculture suffers. 'This is a factor of no slight importance in our vital problem of food supply and living costs.

We need six and one-quarter million cords of wood a rear to make our newspapers, magazines, books, pasteboard boxes, and other products manufactured from wood pulp. We are meeting this need at present only by importing a third of our paper or paper-making materials from Canada. We require from one hundred to one hundred twenty-five million railroad ties each year to keep up and extend our railroad lines, aside from enormous quantities of timber used in other forms for railroad construction and the building of cars. We have to have at least six billion feet of timber yearly for boxes, crates, and barrels, a requirement which is steadily increasing. In sereral highly de- 
veloped agricultural regions an assured supply of containers for shipping farm products to market has become a serious problem in itself.

A group of our important manufacturers, the makers of wood veneers, handles, vehicles, furniture, and agricultural implements consume one and one-half billion feet of timber yearly. It is upon this group, perhaps, that the growing shortage of timber falls most hearily. since they require largely high grade hardwoods and other timber which the virgin forests of the United States furnished so lavishly, but which it is now becoming more and more difficult to find in sufficient quantities.

All told, we demand of our forests about fifty-six billion feet of timber yearly, aside from well orer one hundred million cords of small material for fuel and rarious chemical products. There is nothing comparable to this enormous use of wood in the history of the world. We are preeminently a wood-using nation. It is wood that has dereloped our farm lands, that has largely built and equipped our railroads, and that supports many of our most valuable and distinctive manufacturing industries. We use from two to four times as much wood-for every member of our population - as the most highly dereloped countries of Europe. The abundance and general distribution of our native forests have had a tremendous part in the domestic and industrial derelopment of the $L^{\top}$ nited States and in its conmercial supremacy. We can not face the future without a sober and intelligent consideration of that fact.

Even with the large substitutions of other materials for lumber, the L'nited States with its growing population can not greatly reduce its present total use of wood without serious injury to its home building, its agriculture and its manufactures. And we must find out how to supply our own needs largely from our own resources, for it is doubtful if lumber imports can be greatly increased within reasonable prices.

So much do we ask of our forests. How far can our forests fill this order?

The original forests of the United States are supposed to have covered eight hundred twenty-two million acres. Orer two-thirds of this area has been culled. cut-over. or burnt. There are left todar about four hundred sixty-three million acres of forest and cut-over land of all sorts, which contains about two thousand two hundred and 
fourteen billion feet of timber of merchantable sizes. 'Three-fifths of the timber originally in the United States is gone.

All told we are taking about four times the amount of wood out of our forests every year which we are growing in them. We are cutting more of every class of timber than we are growing. We are even using up the trees too small for the sawmill, but upon which our future lumber supply depends, three and one-half times as fast as they are being produced.

Of still greater significance is the fact that the timber left is not in the right place. The crux of timber depletion is the exhaustion, or partial exhaustion, of the forests most available to the great bulk of our population, agriculture, and manufactures. One timber region after another in the eastern states has been cut out. Less than five per cent of the virgin forests of New England and about twelve per cent of her original stand of timber are left. New York, the leading state in lumber production in 1850, now manufactures only thirty board feet per capita yearly, or not more than a tenth of the requirements of her own population and industries. Pennsylvania was the leading lumber manufacturing state in 1860 . She now cuts less than the amount consumed in the Pittsburg district alone.

The original pine forests of the Lake States, estimated at 350 billion feet, are now reduced to less than eight billion. In 1892 the sawmills in the region bordering the Great Lakes cut nine billion board feet of lumber and largely supplied the softwood markets of the Prairie and Central States and eastward to New England. Today their yearly cut is a single billion. These four densely populated regions, stretching from the Atlantic to the Prairies, which formerly were lumber exporters and still contain enormous areas of forest land, are now partly or largely dependent upon timber grown and manufactured elsewhere and are becoming increasingly dependent upon timber which must be shipped the width of the continent.

The bulk of the building and structural timbers used in the eastern and central states during the last twenty years was grown in the pine forests of the south. But the cut of southern pine is now falling off and within another decade promises to exceed by little. if at all, the requirements of the southern states themselves. The shifting of the hardwood industries has followed much the same course. The principal reserve of hardwoods is in the Southern Mississippi Valley and 
even here it is doubtful if the cut of hardwood lumber can be materially increased for any great length of time. The scarcity of high grade oak, poplar, ash, hickory, walnut, and other standard hardwoods is now confronting many industries with a difficult situation.

One-half of the timber remaining in the Continental United States is in three states bordering the Pacific ocean. Sixty-one per cent of it lies west of the Great Plains. Since 189t western timber has been filling gaps in the eastern and middle western markets. Within the past year it has assumed a dominating place in the principal markets of the Lake States and has largely replaced southern pine at many consuming points in the Central States. It is estimated that within the next decade the shortage of nearer timber will compel the Eastern and Central States to increase their annual consumption of western timber by eleven and one-half billion board feet.

The true index of timber depletion is not in the quantity that is left but its arcalability. This is shown partly in the cost of transporting the average thousand feet of lumber from the sawmill to the user. Prior to 18.50 when the great bulk of our lumber was manufactured near the points of use, the transportation cost areraged less than $\$ 3.00$ per thousand board feet. 'Today it is probably $\$ 10.00$. In another decade, at the freight rates now prevailing, it will reach $\$ 15.00$ per thousand feet. But aside from rising freight costs, the exhaustion of nearby supplies of timber imposes upon the consumer all the disadrantages of being dependent upon distant and restricted manufacturing regions. These include congestion of transportation, the effects of labor shortages and bad weather in limited regions, and a narrowed field of competition.

Not only is the quantity of timber left in the United States being used up much more rapidly than wood is being grown; the availability of the remaining timber to the average consumer is steadily decreasing. 'The situation which confronts us now will be different only in degree if we allow the western forests also to be exhausted and are compelled to import most of our lumber from Siberia or South America.

Doubtless the extreme conditions of the present lumber markets will be relieved in no great length of time and more moderate prices will prevail. 'The outstanding fact remains, however, that lumber price levels higher than those existing before the war must be expected because of the depletion, or approaching depletion, of our forest regions 
east of the Great Plains. We are fast losing the great leveler of lumber prices, the competition between different forest regions available to a common market. The scarcity of forest products of high quality, cut from old growth timber, will not be readily or quickly overcome. Meantime forest depletion is going steadily on, unchecked. It must lead inevitably to rising price levels under normal conditions. It will contribute to sudden and excessive increases in lumber prices in any future transportation, labor, or other crisis.

The real cause of our timber depletion is idle forest land. Shortages of wood have not resulted primarily from the use of our forests, but from their devastation. The kernel of the problem lies in the enormous areas of forest land which are not producing the timber crops that they should. 'There are 326 million acres of cut-over timber lands bearing no saw timber in the United States. Their condition ranges from complete devastation through various stages of partial restocking or restocking with trees of inferior quality, to relatively limited areas which are producing timber at or near their full capacity. On eighty-one million acres there is practically no forest growth. This is the result of forest fires and of methods of cutting which destroy or prevent new timber growth. There were twenty-seven thousand recorded forest fires in 1919, burning a total of eight and one-fourth million acres. During the preceding year, twenty-five thousand fires burned over ten and one-half million acres of forest land. An additional large acreage was burned each rear, of which no record could be obtained.

The area of idle or largely idle land is being increased by from three to four million acres annually as the cutting and burning of forests continue. The enormous area of forest land in the United States not required for any other economic use, estimated at four hundred sixty-three million acres, would provide an ample supply of wood if it were kept productive. Depletion has resulted, not from using our timber resources, but from failure to use our timber-growing land.

It is unthinkable that the United States should be compelled to steadily contract its use of timber-down to the level of civilized existence as in other countries of western Europe. We are not an old world nation. We still have millons of acres of raw agricultural land to be developed. We still have millions of homes to be built and thousands of miles of T-rails to be laid. We are at the threshold of the 
greatest opportunity to expand our world trade in manufactures which we have ever had. It is unthinkable, I say, that, in the face of these vast requirements and opportunities, the people of the United States should be content to watch one of their essential and readily renewable raw materials become steadily scarcer and less available; that they should accept famine prices on timber as a normal condition, with enforced contractions in its use, embargoes, and governmental restrictions. And such a course is as unnecessary as it would be disastrous.

We have an ample area of forest-growing land, over and above any probable demands for farm crops, most of it indeed unfit for cultiration-an area ample to meet all of our timber requirements if its timber-growing capacity is but put to use. From every hand, during the last few months, we have been told to increase production as the cure of our economic ills. I submit that increased production from land is as necessary as increased production by human labor. The idleness of millions of acres of forest-growing land may be even more disastrous in its ultimate effects than the idleness of hundreds of thousands of skilled mechanies. And we have in America today an area of idle forest land equal to the combined forest of Continental Europe aside from Russia.

'The answer to the forestry problem of the U'nited States is not to use less wood but to grow more-to put our idle acres of burned and logged-off timber land at work growing trees. This is not inherently a difficult thing to accomplish. It is not the Utopian dream of a technical enthusiast. Three-fourth of it lies in preventing forest fires. But it does require an aggressive national policy of reforestation. It requires concerted action by the national and state governments to do the things which must he done hy public agencies. It requires the active participation of the private forest owner. It requires a clear definition of public and private responsibilities as to timber-growing land, with an equitable showing of the cost. There is no phase of our whole problem of an assured and perpetual supply of timber that cannot be met by simple and obrious measures once the constructive effort and capacity for organized cooperation of the American people are put behind them.

It is no exaggeration to say that abundant and well distributed forests have been a vital factor in the prosperity of the U'nited States. It rests with us to say whether they will continue to be, or whether we 
must read just our internal and industrial development within the next half century to a basis where wood is an inported luxury. The last two years have shown all too clearly what that actually means. We can no more continue to draw indefinitely upon the timber stored up by nature than we can draw upon the natural fertility of our farm lands without maintaining and restoring it. Let us safeguard the sources of our national wealth and show that we have the thrift and constructive ability to use them with intelligence and foresight.

\section{Remarks of Mr. Jones Following Colonel Greeley's Talk}

When I was a student in our university - you can tell from my looks how long ago - there were four classes of men who were properly supposed to come to college or university : the prospective lawyer, the loctor, the preachers, and the teacher. If one had announced that he intended coming to our university to become a forester he would have been thought a freak. We had one engineer, I remember, a long lank fellow. We sympathized with him. We thought he was going to be so lonesome in the world. We little realized that before the present time. thousands of engineers would have left our university and engineering would be among the greatest of the industries in America.

Sometimes it is difficult to tell what profession one should join. I heard of one good father and mother, with their only son John, who were asked what they were going to do with him. The father said he had talked of this a great deal with the mother and they concluded that John must be a lawyer or a doctor, and on thinking it all over they had concluded that they would rather take him law than his medicine, and he was going to be a lawyer.

We have here tonight one of that class belonging to the teaching class, one who elected to become a professor. We who live in Madison knew him very well. We knew his father and mother and his grandfather and grandmother and everyone before him. I knew him particularly well because I was his nearest neighbor. I watched his antics and his pranks as a boy, and they were just as harmless as the pranks and antics of other boys. I supposed that in a little while he would grow up and marry and settle down and become a hardware merchant or a lumber merchant following the ways of his ancestors. By-and-by 
we heard that he was a shark in mathematics, and we began to hear that he was a shark in physics. We did not know any more about physics than we did about Hebrew, but we were glad to have a shark among us. After a while we were glad that he became a professor in our university, and we were prouder still, though somewhat sad, when he was called to Yale. Then after he left us we began to hear that he was one of the greatest physicists in America. We were glad to hear also afterwhile that he had concluded to come back to his old university, his old city, and his old fishing grounds.

Then the war came on, and we began to hear that our friend was experimenting out on Lake Mendota to further the demands of our country for means to check the adrance of the Kaiser and Hindenburg and their submarines in their attempts to sink the naries of the Allies. We thought it was a pretty big job he was undertaking. and a rather small field for his operations, but we had faith in him, and presently we heard of his experiments along the Atlantic Coast; and then we heard that he had actually invented a derice that would detect the coming of the submarines. Then we heard that he had been called crer to England to consult with the scientists and the naral experts of the Allies-and finally he came back. He is here tonight. He has been called upon to step into the breach to take the place of a celebrated engineer who had intended to come.

I have the pleasure of introducing Professor. Max Mason who will speak to you. 


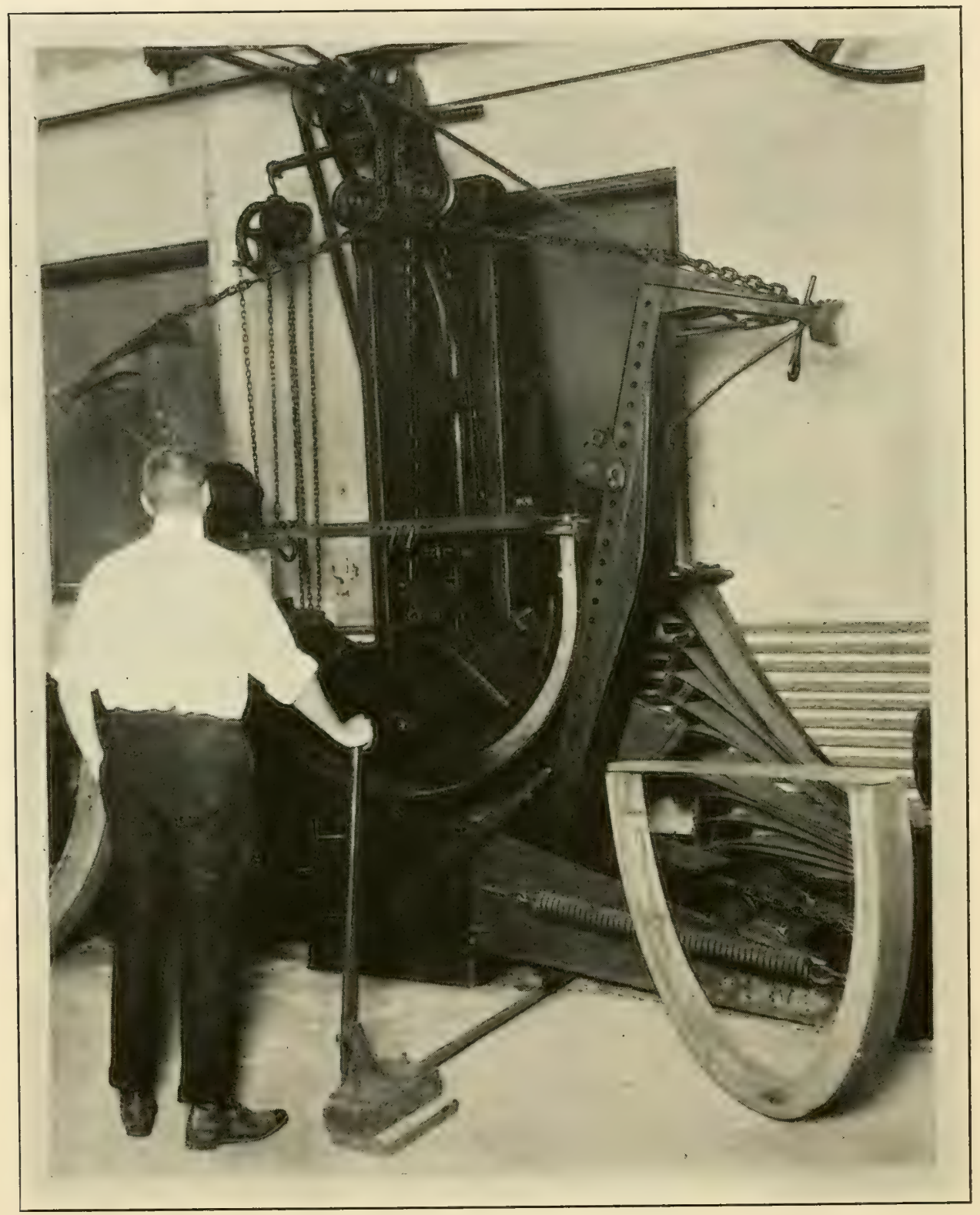

BENDING OF HEAVY WHEEL RIMS 


\section{THE SUBMARINE DETECTOR}

\section{Professor Max Mason, University of Wisconsin}

\section{Ladies and Gentlemen:}

Our experience in the attempt to develop some ways which would aid in combating the German submarine warfare began shortly after our entrance into the war with a meeting called by the National Research Council in Washington. Physicists from America were summoned to hear a discussion of the ways and means of meeting the submarine combat by the British and French naval and scientific men who were sent to America for the purpose of giving American research a running start: and in the course of two or three days we were told of the naval methods of combating the submarines and of the scientific research which had already been started and which had resulted in the perfection and installation of some detective devices.

We were shocked at that time to realize that the enormous loss through the sinking of ships - that was in the early days of 1918-were being accomplished by a marvelousty small number of submarines. From the experience of the British and French navies combined it was estimated that only 12 or 14 submarines were on duty at one time, and we left that conference with the thought that if 12 or 14 can do this damage, and if submarines can be constructed rapidly and manned rapidly, what an enormous amount of waste would result in the near future.

At that time there was no adequate defense against submarines. The British naral officers summed it up in this way: "I have not much to tell you of our submarine work. It consists of the following action. $\Upsilon Y^{r}$ e get a wireless message that a ship has been torpedoed and we send out a boat to pick up the survirors." About that time the nary's use of depth charges and the institution of the convoy system effectively changed things so that the situation cleared up greatly.

In the early days a destroyer would take one or two depth charges and some cans of ' $\mathrm{TN} T, 300$ pounds each, and if they were dead certain ther were near the submarine they would drop a can of TNT thinking they had probably destroyed it. In later days destroyers went 
out with their ship decks loaded with depth charges up to 100 in number and toured over the sea, dropping in a definitely ordered spiral as many as 60 depth charges in 10 seconds of one another; and, of course, if they did not destroy the submarine they shook up the personnel so enormously that it became very unpleasant in the submarine.

The great problem was to find where it was, and that was the problem which the National Research Council wished to solve. What detective device could be used to determine the position of the submarine when completely submerged? I will not and can not give you in a short time the number of devices which were attempted to detect submarines. Probably if you took a large text book on physics and read every chapter you would not find any physical phenomenon which was not attempted, which was not utilized in some way, to attempt to detect submarines by virtue of that phenomenon-light, sound, heat, electricity, magnetism, everything - but the thing that seemed most promising was sound, for a machine can not move without making a considerable noise. Unfortunately a submarine does not make much noise. The efforts we made in Wisconsin towards detecting submarines were based upon the method of determining their position by the sound they make. That is not an easy problem.

The submarine makes a noise like that of a humming bird in a boiler factory, the factory corresponding to the ship and the humming bird to the submarine to be detected. You can imagine what it would be if you were clattering down a cobblestone street with a threshing machine and an electric automobile was somewhere distant and you were trying to determine just where the automobile was at every instant. You could not do it.

The plan which occurred to me in relation to the detecting device was to work with sound in some such manner as we are familiar with in light. You cannot see a star in the daytime but if you sufficiently screen off the disturbing light from the skies and utilize a deep well or a telescope you can see it in the daytime. If you can get some method of intensifying sound from one direction only and shutting it off from all other directions you might be able to detect a fair portion of one sound by thus eliminating the others, and the instruments we developed were based on that theory. We started working here with the generous and cordial support of the University of Wisconsin regents. We soon moved to New London, and there under the naval 
auspices continued throughout the war. A special board of the navy was formed to deal with anti-submarine derices, and under their direction rapid experiments dereloped, with the training of physicists and the installation of devices.

I have a few slides illustrating this work which we will go through and I will attempt to describe, without going into technical detail, some of the features of the work. slides.)

(The remainder of Mr. Mason's speech was descriptive of the 


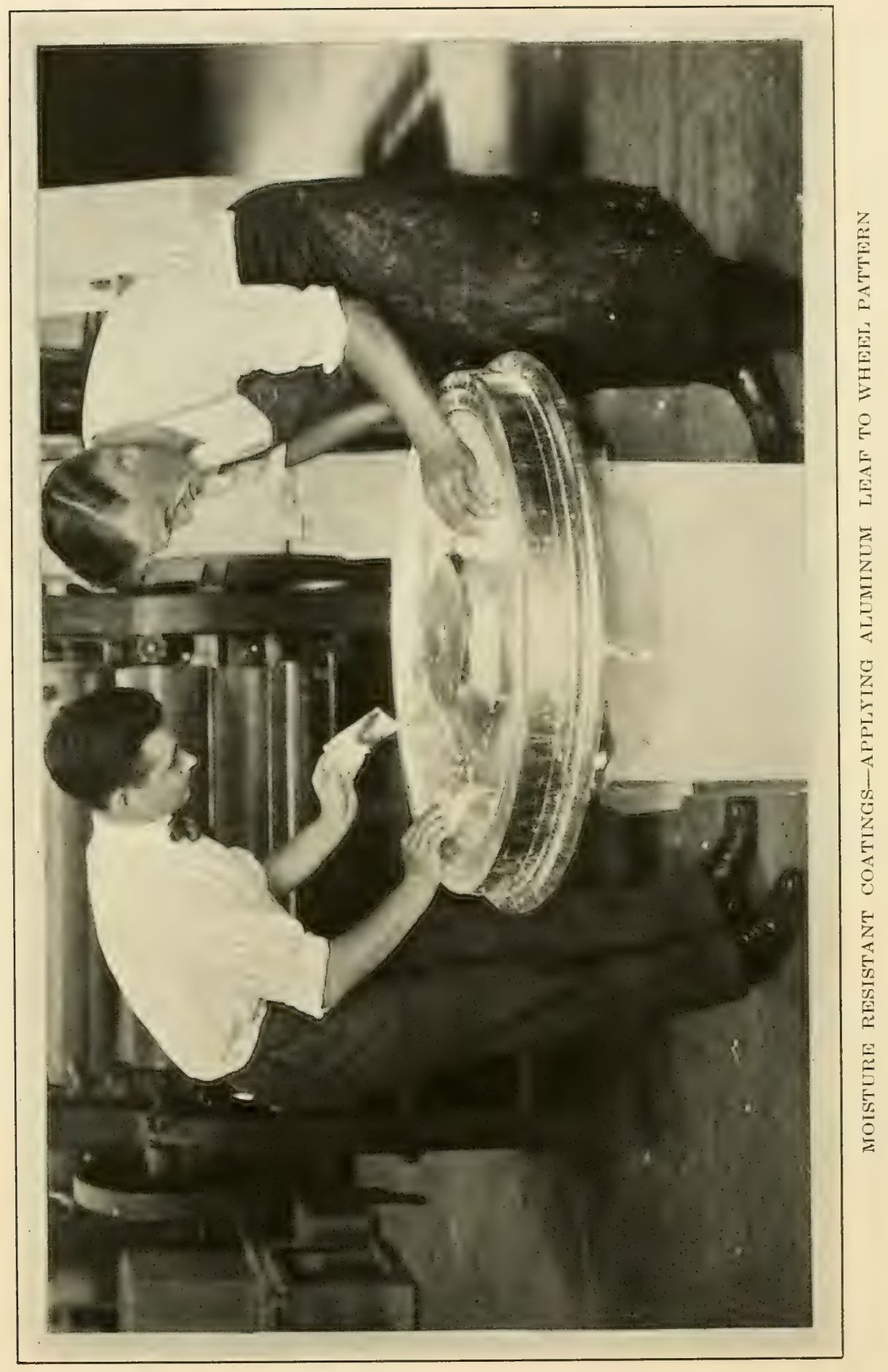




\section{IN'TRODUC'TORY SPEECH}

\section{John Foley, Chairman, Forester, Pennsyliania Railiay System}

Ladies and Gentlemen:

It must be a great satisfaction to the committee on arrangements for this Decennial Celebration of the Forest Products Laboratory as well as to the members of that organization to see this large attendance on the second day of their celebration. It shows that you enjoyed the instructive and interesting program of yesterday. Those of you who were not here yesterday will doubtless be sorry that you did not come. Those of you who have been here before are glad that you have come again and those who are in Madison and at the laboratory for the first time will undoubtedly go away resolved to come again.

A good many people who would have liked to be here were malle to come. and if you will indulge with me a moment I would like to have you hear what they have to say in regretting their inability to join you. Here is a letter addressed to Director Winslow by Mr. McGarvey Cline whom you heard mentioned yesterday as the first director of the Forest Products Laboratory.

"In this morning's mail, I received a program of the Decennial Celebration of the Forest Products Laboratory. It recalled to my mind the early struggles which led to its establishment. My hope in those days was to build so well that the work which the laboratory represents should take such deep root that it would be immune to the storms and uphearals which so often disturb the continuity of research work. Mr pride in the laboratory is almost paternal, and I congratulate you most heartily upon what you have done in making it almost an essential element in the erolution of the forest-using industries.

"I regret keenly, howerer, that I cannot be present at the Decennial Celebration. I would enjoy so much being with you and other members of the Old Guard when you celebrate the successful completion of the tenth year in the life, which I hope will endure to a ripe old age.

"Give my regards to Weiss, Greeler, Burgess, President Birge and any other old friends of mine who are with you during the period of festivity." 
We have a letter from Dr. Stanley Coulter whom all of you know as one of the most prominent men in conservation movements:

"I acknowledge with thanks invitation to be present at the Decennial Celebration and regret that it was not received in time to allow me to arrange my plans so as to be present. As a matter of fact it was forwarded me here.

"The work of the Forest Products Laboratory has been of such scope and significance that anyone interested in conservation problems would feel eager to have a part in a celebration recognizing its past achievements and at which one would doubtless learn something of its plans for the future.'

Those of you who have been in touch with the derelopment of the naval stores industry and the conservation of rosin due to the improved methods of tapping yellow pine trees for resin are familiar with the name of Dr. Charles Herty who did such excellent pioneer work in the derelopment of the present methods of turpentining. Dr. Herty wires congratulations and best wishes to the Forest Products Laboratory regretting his inability to attend the Decennial Celebration.

Not only Dr. Herty who started the work but those who have henefited by the researches of the laboratory in pine distillation feel regret at not being here. We have from the Turpentine and Rosin Producers' Association a telegram reading as follows - "Congratulations on accomplishments during your ten years at Madison."

Not only in the United States are there those who wish the laboratory well but we have from Erie. Pa., a telegram from the representative of the Norwegian Government- "Meartiest congratulations to you and all your friends at your grand institution."

The following letter from Cheltenham, England, was received"I thank you and your committee for your invitation to attend the Decennial Celebration on July $22 \mathrm{2nd}$, but regret that it is impossible for me to attend. I take this opportunity of expressing to the General Committee and especially to Professor Winslow, the great assistance which the publications which he was good enough to send me. have been to the Committee on Aeroplane Timber, of which I was Chairman. and thank you most heartily on behalf of the Committee for these most valuable papers."

As you all know there is in the U'nited States a Chamber of Commerce which represents in the business life the institution which is sup- 
posed to correlate all of the activities of the rarious chambers of commerce and boards of trade. Its president writes:

"I wish again to express my regret that $I$ shall be unable to attend the Decennial Celebration of the Forest Products Laboratory, to be held at Madison, Wisconsin, on July 22nd and 23rd.

"I am happy to advise you, howerer, that I have found opportunity to ask Mr. E. W. Mc ( ullough, who will hand you this letter, and who represents the Chamber as the Chief of its Department on Fabricated Production, to attend. IIis Department is naturally related to the enterprises the Celebration is calculated to forward."

Those of us who hare been coming to the Forest Products Iaboratory with any regularity do not hesitate to suggest to the rest of you that you get the habit. It will not hurt. You will be unahle in these two dars. which are so filled with various other functions, to get thoroughly acquainted with the work across the street, but if you could spend a period of reasonable length, undoubtedly you would get rery much from the laboratory. Then, should you later come back, rou would undoubtedly find changes in the personnel. for the raluable services which its member's can render to industrial institutions result in many of them being taken away, but you would find constantly there the same spirit, the spirit that more actively each year derelops along the line that the Forest Service stands for, that is, usefulness and serrice to the people of the country in providing the wood necessary in its every day life.

You are going to hear today about some of the problems connected with the industries depending upon the forest. The first of these is that which to each of you represents what you get in the newspapers every day and in the magazines you read, forming the astonishing amount of 35 pounds of paper to each man, woman and child in the United States erery year. When you think of the paper that is used for other purposes besides newspapers it makes the total of over 100 pounds of all kinds of paper consumed by each of you every year. It is natural to assume that in the production of that rast amount of material there are a great many problems and on those problems we are going to hear from Mr. Ererest. General Manager of the Marathon Paper Mills Company. 


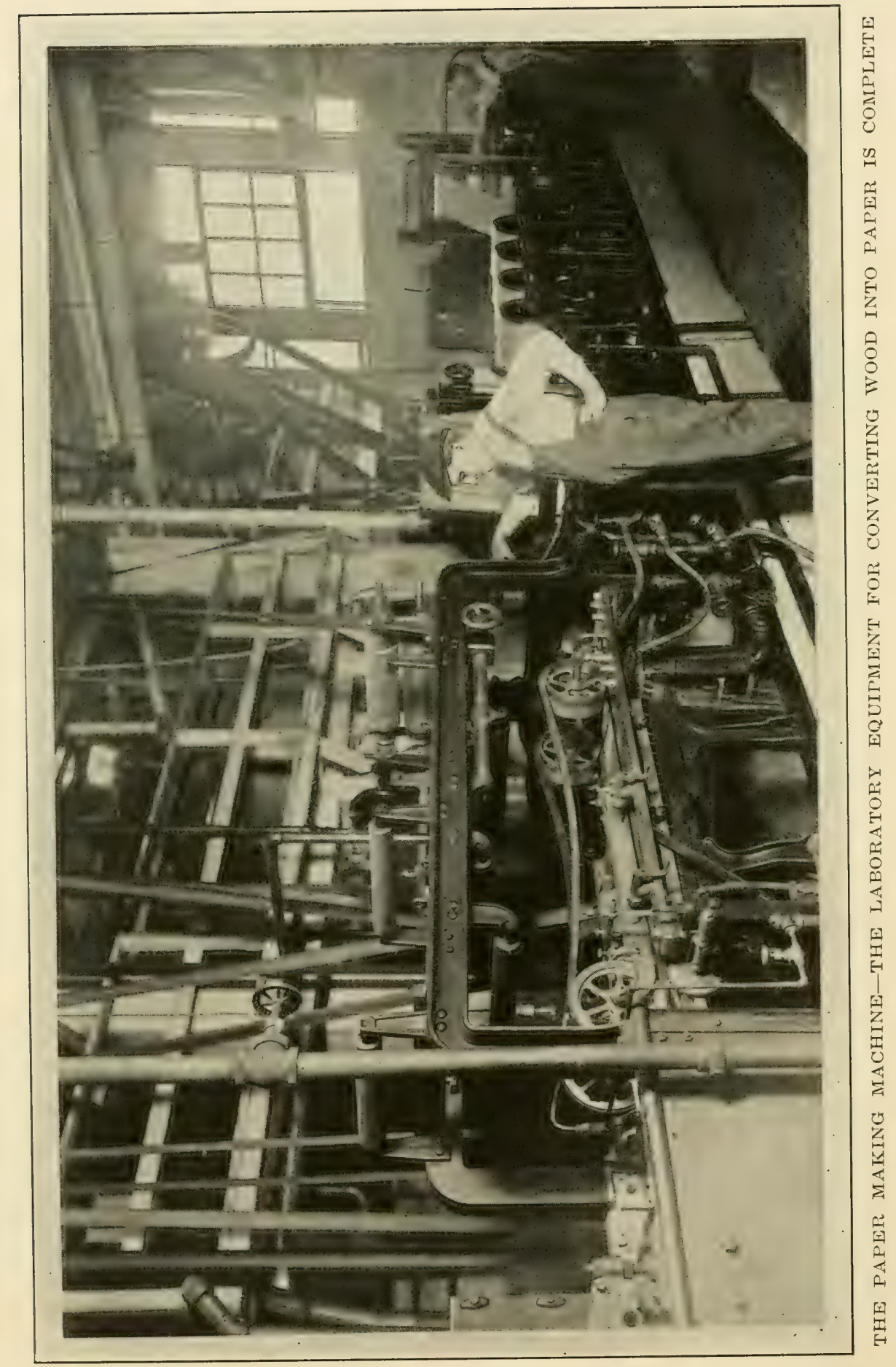




\section{SOME PROBLEMS OH' 'THE PLLP AND PAPER INDL'T'TY}

\section{C. Everest, Secretary and General Manager, Marathon Paper Mills Company}

Mr. Chairman and Gentlemen:

In presenting some of the problems in which the Pulp and Paper Industry is interested, I intend to deal only with those which relate to the work of the Forest Products Laboratory and which we expect to be able to solve by intelligent cooperation with this institution.

In the beginning I wish to say that eren though this laboratory has been in existence for ten years, Paper and Pulp manufacturers have not taken advantage of its remarkable facilities to any great extent, and, as a matter of fact, only comparatively few yet realize what a wonderful asset we have in this institution. What I have said of the Paper and Pulp industry, I believe applies equally as well to other branches of industry represented here today and those which have to deal with forest products in any form.

Had we as manufacturers of forest materials awakened to the value of the laboratory to us and taken the interest in it, which is now apparently manifested, there would be fewer problems of our various industries today. Men connected with this institution have, from the time of its establishment, been anxious and willing to cooperate with manufacturers in any way and have only been prevented from rendering greater service on account of the failure of manufacturers to acquaint the laboratory personnel with the problems confronting them. For ten years the men here have tackled every problem which has been put up to them and have rendered invaluable service to those who have realized the necessity of such work and have made use of the laboratory in the manner intended when this institution was established.

The present situation in the paper industry, abnormal as it is, has directed the attention of more manufacturers to the need of immediate and definite action in attacking the rarious problems with which they are confronted. The attitude in the past has been to take advantage of the improvements only as they have been made by a few pro- 
gressive manufacturers, and a tendency to procrastinate, even in this, has been rather common. The condition of the industry looking to the immediate future demands that these problems be attacked in such a manner as to produce definite results in the shortest time, for with the growing scarcity of pulp wood in the eastern and central states and our increasing dependence upon Canada for the supply of raw material, a situation has been created which can be rightfully viewed with alarm. While some research either in a haphazard manner or following a carefully coordinated plan has been carried on by the paper industry, it is safe to say that only those organizations in which the program of research was definite have succeeded in placing the manufacture of their products upon a sound basis and are now able to take full advantage of their foresight.

When research is mentioned among paper mill men, and other timber users, too often the audience is unsympathetic if not hostile, and the tendency of many mill operators has been to look with disfavor upon the efforts of investigators along scientific rather than the immediate practical lines.

In spite of all this, the pulp and paper section of the Forest Products Laboratory has been striving for the past ten years with funds and personnel inadequate for the work in which they are engaged to solve some of the pressing problems of the industry. The field is a large one, and most of the work pioneer in character. How successful they have been in their work may be judged from the following recital of the major problems which they have attacked and are now studying.

The need for definite specifications to corer the purchase of pulp wood has long been recognized. That the present basis of purchase, using the cord as the unit of measurement, is inaccurate cannot be doubted. The ordinary piled cord $4^{\prime} \times t^{\prime} \times 8^{\prime}$ may, depending on the diameter of the bolts, freedom from knots, etc., contain by actual measurement from 104 to $65 \mathrm{cu}$. ft. of solid wood. Further, the present method of buying wood does not make a proper allowance for the percentage of decay. More than four years ago an attempt was made to interest pulp mills in this problem, but until very recently nothing has been accomplished. However, field work financed by the American Pulp and Paper Association is now under way, and no doubt exists but that the results accomplished will meet expectations. 
Closely connected with this problem, and of more rital importance due to the growing scarcity of pulp woods, is that of rossing. chipping, drying and baling of pulp wood preparatory to delivery to the pulp mill. With the vast pulp wood forests of the West practically intouched, it is felt that some such method as this may offer a solution to the decreasing supply of pulp wood in the East. 'This is now a cost of transportation problem.

For many years the enormous amounts of the unavoidable waste in the lumber industry has challenged attention. Few pulp mills, however, have been in a position to utilize this waste, and have depended upon round wood for their supply. Conservation of timber resources will in time compel the utmost utilization of this waste, and the time is not far distant when lumber mills will undoubtedly undertake the barking of edgings and slabs, chipping and screening the wood and selling, in the case of hemlock, the bark to the tanneries.

The utilization of hemlock bark obtained from the barking drums has already been the subject of study upon semi-commercial scale, and and it only remains to bring the tanner and pulp man to a mutual inderstanding of each other's problems. The burning of such bark is indeed a great waste if the value for tanning purposes as shown by the semi-commercial test is actually proved in the commercial tests to be made. and there now seems to be no question about its being worked out satisfactorily.

'The increasing cost and scarcity of wood labor has both reduced the supply and increased the ralue of hemlock bark. And in addition, the inability of the lumbermen to deliver peeled pulp wood to the pulp manufacturer has further increased the cost of this commodity.

'The woods of the national forests, particularly those of the W'est, hare been the subject of an intensire investigation looking toward their utilization by both mechanical and chemical processes. All the more important pulp wood species hare been investigated, and samples are arailable on practically all the woods of importance from a pulpmaking standpoint. Local and economic conditions still remain to be studied. and since a great deal of this work was done prior to 1914, the greatly changed conditions necessitate a further survey.

Sulphite pulp can best be produced from the non-resinous woods, and the decreasing supply brings into importance the possibility of reducing resinous woods by this process. A successful solution of this 
problem would make available many cheap woods which cannot now be used and to a decided extent assist in overcoming the wood shortage.

The possibility opened by the use of liquid sulphur dioxide, which can be obtained from the smelters, in the manufacture of sulphite acid has been a subject of much speculation, and while semi-commercial scale studies have pretty clearly indicated the results to be expected, it still remains for a mill scale demonstration to be made. The largest source of this material is, of course, in the West, and in addition to offering an outlook for an extremely objectionable nuisance, it would go far to eliminate the damage to which all vegetation in the vicinity of a smelter producing such fumes is subjected.

In line with the policy of conservation of by-products, investigations have been planned and carried out on the uses of waste sulphite Iiquor for the production of alcohfol, binders, tanning materials, etc. When one considers that approximately one-half the weight of the wood is dissolved during the course of the coking treatment and ordinarily runs to waste, some idea may be gained of the immensity of this problem. It may be that in time to come, the relative importance of the products of pulping may be reversed, as was done in the coke industry.

Hardly a sulphite mill exists but that experiences trouble with "pitch", and in spite of this, but little has been accomplished along the lines of pitch elimination. The laboratory equipment is too small to permit a comprehensive study to be made of this problem, but analyses in conjunction with changing cooking conditions will doubtless throw a great deal of light on the subject.

The study of fundamental cooking conditions in the soda and sulphate processes led to the development of a modified method of producing sulphate pulp. By this method decreased chemical and steam consumption and increased yields were obtained, and while it has been impossible to conduct an entirely satisfactory mill scale trial, no doubt exists that this method is worthy of wide use.

Although sulphate pulp is not usually considered as easy bleaching, indications are that it can be successfully bleached, yielding a fair color with a higher ultimate yield than wood pulped by the soda or sulphite process. A pulp- and paper-making trial has just been completed where southern pine pulped by the sulphate process has been bleached, and used to a large extent in the production of a satisfactory 
magazine sheet. This has been done without undue cost or sacrifice in yields.

One of the questions which is rery frequently the subject of conversation when sulphate mill men get together is the relative advantages of diffusers and pans. 'This problem, however, can only be successfully attacked upon the mill scale, and the same applies to a study of the cause of corrosion of diffusers.

The successful recorery of chemicals from the waste liquor has always been of great importance, and any means which can be devised to raise the percentage of recovered chemicals would immediately be reflected in a decreasing cost for manufacture. Here again but little can be done upon a small scale.

Paralleling the recovery of by-products from sulphite liquors, distillation of those obtained in the soda or sulphate process offers a means of more fully utilizing the present waste. It is definitely known that valuable products exist in the black liquors, but their recorery upon a commercial scale is not yet a complete success.

Salt cake has been universally used in the sulphate process to make up the chemical losses, but the use of niter cake offers certain advantages which, howerer, are offset by a few serious drawbacks. If opportunity could be given for a thorough investigation into the use of niter cake, this problem might be solved.

A constant source of trouble in the sulphate mill is found in the refractory material used in lining the smelters. While the conditions existing in a sulphate smelter doubtless offer great difficulty, it is not inconceivable that by intensive study a solution for this problem can be found.

Woods which are pulped by the alkali process lend themselves very readily to recorery of rarious products prior to pulping. So far, however, tannin is the only product which is now recovered on a commercial scale, but the high rosin and turpentine content of the southern pines suggest that before long these materials will also be recovered. This problem can be very successfully attacked upon a laboratory scale and has already been too long delayed.

There are but few quarries in this country where a successful grade of stone for pulp grinders is found, and the cost of the work necessary to experiment with new deposits is practically prohibitive unless the investigations can be first carried out upon a laboratory 


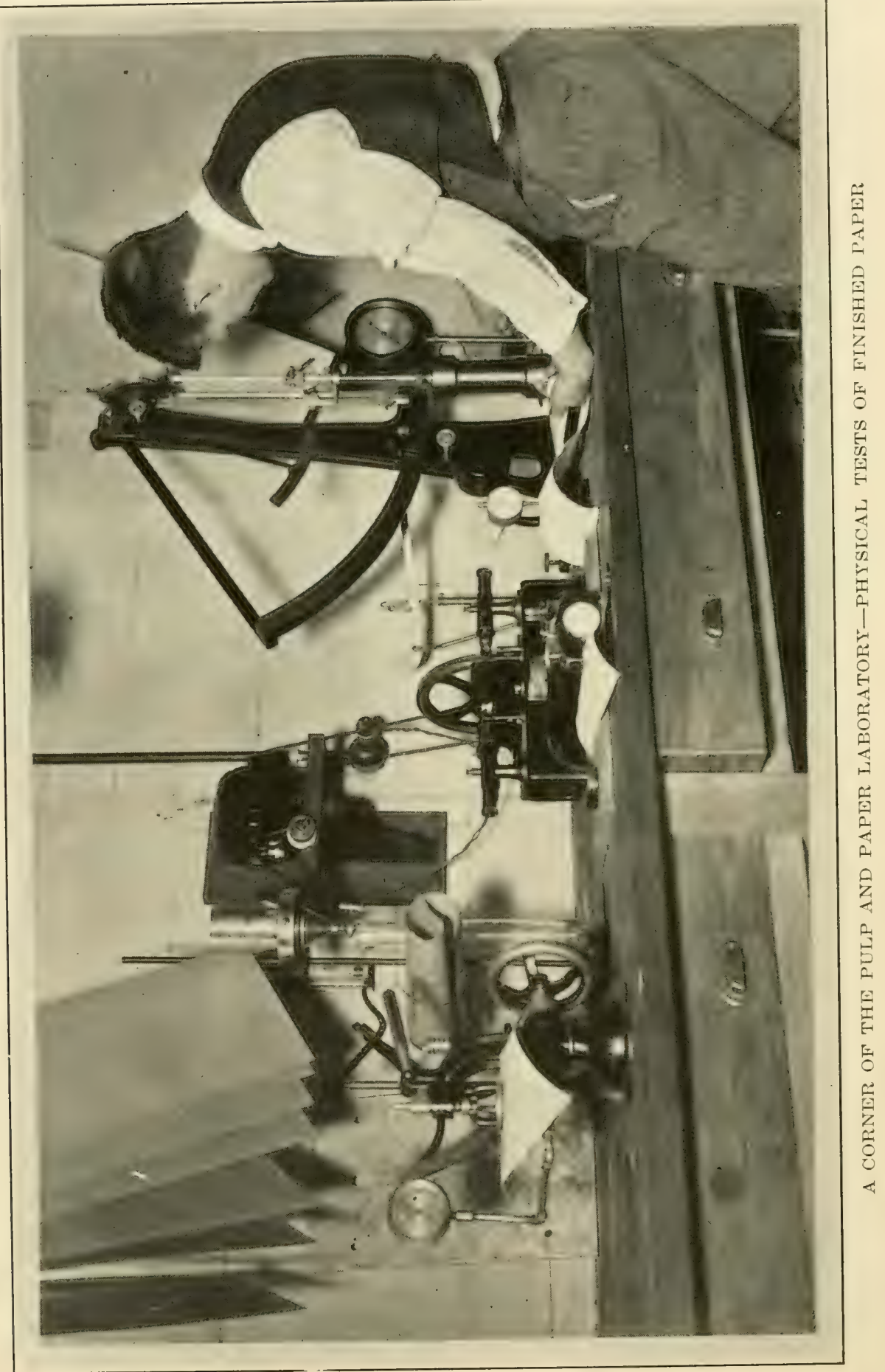


scale. C'losely connected with this problem is that of dereloping a suitable artificial stone, and while many abrasive materials have been suggested, and some tried, the problem is not as ret solved. But here again the laboratory can be of great assistance.

The importance of keeping under control the production of mechanical pulp is receiving increasing attention, and a number of years ago was the subject of some study. Since that time. howerer. no opportunity has been presented for the laboratory to continue this work. although nill organizations are carrying on investigations along this line.

The loss of fibre in whitewater has been the subject of much discussion in the past. hoth from the standpoint of stream pollution and improving plant conditions. Because of the large volume of water which must he handled in order to recover the relatively small amount of fiber, certain difficulties present themselves at the start. But progress has certainly been made in the solution of this problent. and much more can be done if the matter is made the subject of an intensive studry.

'The eff'ect of the various factor's entering into the beating of pulp) is not entirely understood. although progress is being made along these lines. In spite of the work that has been done with experimental beaters it is not yet possible to apply the results obtained upon a small scale to mill conditions.

In connection with the conservation of waste materials, the recorering of various waste papers such as paraffine and asphalt commands attention. Because of the difficulty of collecting these waste products. but comparatively little progress has been made, although the laboratory tests have successfully demonstrated that the impregnating material can be recorered without undue cost and the extracted pulp made into a satisfactory sheet. (One mill is now being built for the extraction of paraffine and the manufacture of the waste paper into pulp.

The study of a substitute for sulphate of alumina is a problem of utmost importance at this time, and if transportation conditions remain as they are today, and seemingly no miracle is going to happen to change these conditions under from three to fire years, then we shall need some substitute for this commodity which we can obtain easily, possibly from some materials now employed in our pulp-making industry. The conditions in the manufacture of sulphate of alumina today 
are a serious problem for the paper manufacturers. I understand some work has already been done along that line.

The study of paper specialties such as fiber containers, indurated ware, molded articles, artificial silks, twines and textiles requires a highly organized research body, and progress has necessarily been slow along these lines. Work has been done in an attempt to develop water and grease proof containers, and a certain degree of success has attended the efforts.

Various raw materials other than wood are receiving an increasing amount of attention from the trade, and utilization of one such material: namely, cotton linters, has been successfully carried to commercial scale operations. Others such as the various grasses, straws and crop plants should be the subject of investigations, but must await the solutions of those problems which are more pressing, and which promise more valuable results.

Studies on the chemistry of pulps have been confined principally to the research carried on in the European countries, although the subject is of great importance in connection with the use of chemical pulp for manufacture into various cellulose derivitives. The lack of this knowledge was very forcibly brought home during the war when investigations of the suitability of chemical pulps for manufacture into nitro-cellulose were seriously hampered by our ignorance of the subject. In the study of pulp wood and wood pulp decay, chemistry will, undoubtedly, play an important part in determining the various decomposition products formed by the decay organisms. However, it must be remembered that in all cases where a chemical study of pulp or wood is made, complete data must be available relative to the previous treatment which the material has undergone. Too much work has already been done upon pulps whose origin was unknown. Of the various studies mentioned, this one alone requires the services of several highly trained men, and results could in no case be expected under several years' time.

The beginning of the study of this problem of deterioration in pulp wood and wood pulp to any great extent in the laboratory was brought about by the experience we were having at the mill in which $\mathbf{I}$ am interested, with fungus growth in stored and purchased pulp. Owing to the serious problems of transportation during the war it became necessary to purchase wood pulp in full cargoes and store it 
rather than to depend on regular shipments by rail of freshly ground wood. This storing of large quantities of pulp and particularly in riew of the high market value at the time, soon impressed one with the enormous loss due to deterioration both in money and quality of product. When this problem was taken up with the laboratory it was found that practically all the funds were tied up for other work and that even though the funds were available, the necessary pathologists and others necessary to the prosecution of the work must be found. It was impossible to do anything until funds could be supplied and according to regular practice this would mean waiting until appropriations were made and the money available after July 1st. This meant a delay of nearly a year and consequently I undertook to raise sufficient funds from concerns engaged in pulp and paper manufacturing to defray the expense of this work until regular governmental appropriations would be made to cover it. 'Twenty-three concerns contributed $\$ 10,500.00$, about one-fourth of the concerns addressed on the subject replied to the first appeal and the reasons given by others for not contributing after the second and third appeals were made, showed that there was either a lack of knowledge on the part of many manufacturer's both as to their own needs and as to the ability of the Forest Products Laboratory to handle such questions, or there is an epidemic of "tightwaditis" in this country when it comes to sensible propositions which are to be of benefit to our business and the country generally. Let some one present a proposition involving the expenditure of millions of dollars for the assistance of some fool thing or other and men seem possessed to be the first on the list to give their personal or company funds, but a sensible program looking to the conservation of one of the greatest assets this country possesses is passed up without giving any financial aid and by offering excuses, usually too thin for any use. Many said we are studying this problem in our laboratory, but we had all done that for years and were no nearer a solution of the problem than when we started. It requires the best men obtainable in the country in several different lines and it must be patent to every one that a coordinated program being carried out in one place under such conditions as exist here would vield better results than if men equipped with only general chemical knowledge and working individually should undertake the study of this problem in private laboratories. 
Some replied that this should be a goremment matter and the goremment should provide funds, etc., not seeming to realize that funds were not then arailable and that the loss to every manufacturer due to a delay of six or eight months in the solution of such a problem meant many times the amount they were asked to contribute.

If the Forest Products Laboratory is to be of the greatest possible assistance to the pulp and paper industry closer cooperation must exist with the mills, for the final test of any laboratory trial must take place in the mill. 'Too often information vital to the successful prosecution of a problem is withheld or full and hearty cooperation is lacking. If the mills refuse to give the laboratory their full confidence and at the same time maintain a critical and unsympathetic attitude but little real progress can be made on those problems in which the industry is vitally interested.

If, howerer, they look upon the laboratory as a part of their own organization and treat it as such, correcting its mistakes and commending its successes, the greater portion of any research problem is already solved.

For an organization of this character to be so seriously hampered, both as to equipment and personnel, is fatal to a rapid solution of the many problems with which it is confronted, and it is. of course, impossible to carry on intensive studies of the many pressing questions. Should a mill organization desire work done, the results of which would be of benefit to the whole industry, a cooperative arrangement can be made similar to the ones now in force with respect to pulp wood and wood pulp decay and pulp wood measurement. Or one or more men. financed by the mills, could be detailed at the laboratory for an intensive study of some problem under the direction of the laboratory organization. Either of these suggestions is in accordance with the laboratory policy of furthering the adrance of exact knowledge of the industry with which they are so closely connected, and their adoption by any organization is most heartily welcomed.

In summing up the problems of the pulp and paper industry, perhaps the one which is as important as any is in seeing that ample appropriation is made for the continuance of this work, so that with the necessary funds, the personnel of this laboratory may be built up to a point where we may rest assured that the problems confronting us may be solved. The personnel is the foundation, and the whole thing 
depends on it. 'The Secretary of Agriculture has been working to have the salaries of these men and women put on a basis comparable to salaries paid in private industry for like service, and in this we must assist him in erery way possible. Adequate salaries must be paid.

The necessity of such action rests not only on the paper and pulp industry but on every other branch of forest products conrersion industry in the country. From my conversation with lumbermen and other's connected with wool-working industry, I am convinced there is a woeful lack of information as to this work and the possible adrantages of it to the individual concern.

'Take, for instance, this prohlem of deterioration of pulp wood and wood pulp. Experiments have demonstrated enormous losses in rield from infected wood and a falling off in quality which is surprising. Heretofore, deterioration of pulp wood and other forest products has lieen looked upon as a matter of course and no great effort made to correct it. We have heard of the rapidly decreasing timber supply, public men how about it, and newspapers harp on it continuously. Conservation has been preached by every man who could get an audience. I umbermen and others of days gone by have been criticised for what was at that time an unaroidable waste of unsuitable timber and what was a necessary waste to open up what is now our best agricultural territory. Criticism of everybody and everything has been the order of the day. but when it comes down to a proposition to finance this laboratory, the only department of the Forest Service which can point the way to conservation of our natural timber resources after they are remored from the land, it is only after the greatest effort on the part of the Secretary of Agriculture, the Chief Forester and all others comnected with that department, together with the efforts of various associations of industry represented here, the splendid work of some newspapers and trade journals and the actual work in committee of Congressman Nelson and Senator Lenroot, that Congress would appropriate barely enough to keep this institution alive for another year.

Another strange fact is that within a few months of the time the appropriation was fixed for the laboratory another committee made up of men from the same body which considered the appropriation, tack on to another bill an appropriation of $\$ \mathbf{1 0 0 . 0 0 0 . 0 0}$ for the investigation of a substitute for pulpwood, cornstalks or sugar cane. The 
same old story of finding substitutes for pulpwood but doing mighty little to find ways to save what we have. Probably none of those who dealt with the Underwood bill recalled that there was a well established laboratory for the purpose which they had not properly supported. If these gentlemen are sincere when they howl "Conservation", then their actions in providing for this institution belie their words. Most people lose their sense of proportion when dealing with large problems. and unfortunately congressmen have proved no exception to this rule.

IVe need this laboratory. Private enterprise cannot buy such facilities and conditions. You who have been privileged to see and know what is being done here must realize that if we are to solve our technical problems relating to timber, its care, perpetuation and proper use, we must back this laboratory to the limit, either by inducing Congress to adequately provide for it or by individual subscription if necessary.

There is but one thing for the paper and pulp industry and other industries using forest products to do, and that is to work earnestly for a better understanding of the possibilities of this laboratory serrice both on the part of the members of their respective industries and of those who have the responsibility and power to fix the sum which shall be expended in this work, and in this manner we may expect to materially reduce the number of problems which confront the pulp and paper industry and your other industries as well.

I urge rou, gentlemen, to give this institution the support it deserves in the solution of the scientific problems affecting our industries and which are so vital to our individual success and the conservation of one of the nation's most valuable natural resources.

\section{Remarls of Mr. Foley Following Mr. Everest's Talh}

In the early days of the world war, most of you heard a great deal about the National Council of Defense, the War Industries Board, and other activities of the Government at Washington. To many they were simply names. To those who spent any time at Washington they quickly became very significant factors in the wonderful work which was being done in developing the necessary forces to resist the progress of the German Army. 
The talk that you heard from Professor Mason last night certainly should have given you an insight into what was done by the scientists of this country in organizing the technical knowledge ther possess and which I assume our German friends did not credit them with possessing. It was coordinating such knowledge and bringing into collaborated effort the experience and the experiments of the various scientists, individuals, and organizations of the country that made our wonderful progress possible. What was learned during the war in the way of effectiveness in such coordinative effort is being profited by to the extent that there is now being maintained an organization called the National Research Council.

We are rery fortunate this morning in having present to tell us about the work of that organization its Extension Manager, Dr. Howe. 


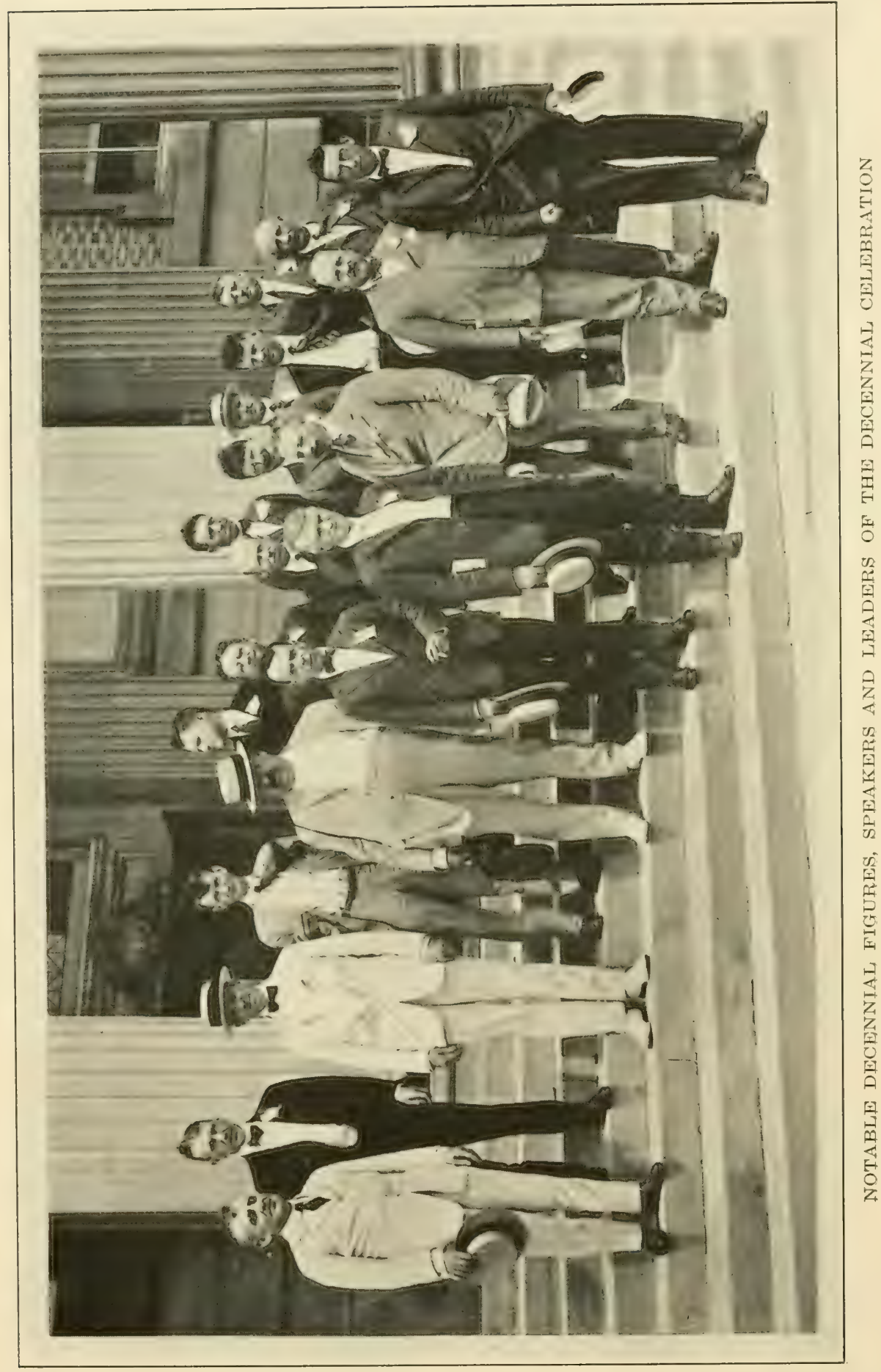




\section{AMERICA'S PLACE IN INDESTRIAL RESWARCH}

\section{H. E. Howe, Chairman, Research Extension Division, National Research Council}

\section{Ladies and Gentlemen:}

The subject which has been assigned to me affords a real temptation to bring out the American eagle and let him scream. 'The easiest way would be for me to make the assertion that America holds first place, and let the other fellow attempt to disprove the statement. I think, however, that we would do well to consider how we are regarded in industrial research. what the present situation is, and what the opportunities are for winning and holding first place. The record makes it rather plain, I think, that America rightfully belongs out in front leading the industrial research procession in many fields and in the majority of the fields of science America has already a very high standing.

Perhaps the best tributes that have been paid to American industrial research hare been from abroad. I can refer you, for example. to Mr. Fleming's discussions in Fngland where he has taken occasion to illustrate various phases of industrial research by reference to the Inited States in the hope that our progress here will stimulate the efforts of our Fuglish friends who may find in our work an example worth emulating.

More recently Holland, considering the establishment of a large laboratory in Java, has taken pains to investigate our Government lahoratories, educational institutions, and the many places where research has turned to the aid of industry.

Our Australian friends who have heen collecting data on research laboratories, routed many of their men who were returning after the war through the United States. These men were given the information wherever they risited, made acquainted with equipment, details of method, reports of progress made in our plans of organization, our greatest activities, and in general the points in our own experience which may aid them in Australia. They have already decided upon the duplication of some of the equipment to be found here at Madison. 
You have heard also of the establishment of the Forest Products Laboratory in Canada, and the Canadian Parliament has planned the establishment of something similar to our Bureau of Standards and the Mellon Institute where the training of men as well as the inrestigation of scientific problems will be the outstanding features. I think, therefore, that the way in which our foreign friends have investigated our conditions and found them satisfactory speaks very well indeed for our position and gives us some right to claim that we are well toward the front in the field of industrial research.

Another piece of evidence on the same point is the status of industries founded on scientific data. I know of no better argument to off er in urging people to undertake research in their own industries, founded upon cut and dry methods, than to point to such experiences.

Many of the older institutions still use rule of thumb methods and refuse to accept the full measure of aid science affords. An example of this is the ceramics industry. On the other hand, our electrical industries and chemical industries have developed much more rapidly than the older industries and are more progressive. These new ones have founded themselves upon science and hold their present status due to scientific endeavor.

In America we have many such industries; the petroleum industry is an outstanding fact of what science can accomplish. I can remind you of the work of Frasch in the elimination of sulphur from petroleum making it possible to use that material from Ohio, Canada and other points for illumination purposes. This, orernight, raised the price of that oil from 90 cents per barrel to many times that amount.

The packing house permits us to enjoy meat products at even the present prices only because of the by-products which have been developed through industrial research. At one time two per cent of the annual turnover was the net profit made by the concerns on the edible products.

The electro-chemical and electrometallurgical industries are conspicuous examples, and we might spend all of the time at our disposal on the progress made, especially during war times. The fact is that these industries gave us our abrasives and whole industries have been built up around our artificial graphite and electrolytically refined copper upon which all electrical industries depend. What industrial research can do in this particular field has been proved, and electro- 
lytic methods of refining metals and making steel will continue to engage attention for some time to come.

In welding we have made quite a record. Without this research we probably could not have repaired the German ships which were in New York harbor. This has always been a very interesting subject to me, for we accomplished in a few weeks what the Germans thought would take years to do. All ships were damaged almost exactly alike, the variations being but slight. Everybody carried out his orders, there being no evidence of individuality in the methods used; and when the results were available from one ship, a method had been worked out for all and it was only necessary to increase the units of the repair equipment. Out of that work the American Welding Institute has grown up and is now engaged upon a study of the various methods of gas and electric welding.

Perhaps there is no brighter page in industrial research in America than the development of the art of communication. In wireless simply marvelous progress has been made and is due wholly to research. Men who learned their radio during the war and have lost touch since, find such rapidly changing conditions that they must almost begin over again. Such progress is being made in the use of new apparatus and the steps are being taken with such rapidity that in order to keep up with wireless the men must keep in touch with each development as it unfolds piece by piece. The wireless telephone strikes me as being one of the most remarkable accomplishments. That we can send wares traveling as from the center of a sphere with such intensity that part of them will reach a distance from Washington to Paris or Hawaii with sufficient force to be heard is a modern miracle.

You heard from Professor Mason last night about research on one type of communication that was carried on in many of our laboratories during the war.

The rubber field is another glowing example of what American research has done; and still another can be drawn from fields of electricity, chemistry and engineering in the Mazda lamp. The use of this lamp is said to mean a saving of $\$ 400.000 .000$ annually as compared with our old carbon electric light bulbs. Our scientific men fought with German scientists for the prize; both knew the advantages of tungsten filament and that ductile tungsten was the next step. Our men were first to solve the problem, and also to learn that the use of 
inert gas in place of a partial racuum in the bulb very greatly increases the efficiency of the lamp. We like to tell of this particular work because much of it began in pure science and has practically intrenched the electric lamp industry in America.

Something that may be of interest, perhaps, is the work which has been done in Hawaii in the use of paper to fight weeds. It is another Yankee invention. Due to the type of soil and the heary rainfall the weeds grew so fast that sugar cane could not be grown at a profit. On one plantation Mr. Eckhardt after many unsuccessful efforts to kill the weeds by spraying, etc., eventually conceived the idea of trying to fight them by putting paper over the rows. This is possible because under the paper you get a hot-house condition. The sharp spikes of the sugar cane have little difficulty in penetrating, while the soft tops of the weeds are unable to get through the paper. The place where the spikes strike the paper obliquely and do not get through is shown by small elevations and a knife incision permits their emergence. 'These rapidly overtake the ones which have penetrated earlier.

A type of roofing paper was used and a few trials on several acres showed the possibility of decreasing the actual cost of production from 50 to 80 per cent, and an increase of about ten tons of cane per acre. due to the elimination of weeds. 'That paper was, however, a rather expensive product and the next step in industrial research was to make this type of paper from Bagasse, which is sugar cane from which sugar has been extracted. 'This has been worked out satisfactorily on a small scale in this country by Arthur D. Little. Inc., and a 20-ton mill is now in operation making sufficient paper to care for the need.

We have heard mention made of the progress of associations in England fostered by the Gorernment. We have in this country associations that are doing equally well and have many years of success behind them.

'The National Canners' Association is an outstanding example of what can be done for industry through cooperative work. It was one of the first in the field. The entire product of the industry has been improved; virtually the whole industry has been elevated. This does not mean that the products of inferior grade before this cooperative work began are now equal to the best, but that the poor ones have been improved and the best ones hare also benefited. The men who were formerly able to make the best quality are still able to do and 
better able with the help of research. Members who formerly fought scientific control now recognize its value and their need for it.

The Portland Cement Association has also accomplished a great deal, particularly in studying types of aggregates which are suitable for concrete. Often failure in concrete is due to the use of excessive water in making the batch. This research work done by the Association proves that if care is taken to use the right proportion of cement to give the proper binder, and not to use an excessive amount of water, any local aggregate when graded and classified can be used. 'This is becoming the general practice for roads and pavements and effecting considerable savings.

The malleable iron industry has been sared from a secondary position by the application of industrial research. When this association began its work the members bound themselves to conform to a high standard specification administered by the laboratory. If a certain foundry was turning out a poor grade of iron, that foundry was risited and steps taken to put its product on a higher level. Those who were making the best iron before this work was undertaken are still making the best iron although the tensile strength and other physical characteristics are higher for the entire industry. Individuals and concerns have been benefited without interfering with the progress which comes from individual initiative, and the resourcefulness of the concerns.

Commercial laboratories are filling a very real need. Many manufacturers who can not afford to establish research laboratories and whose research problems are not receiving the attention of associations find these laboratories very useful and necessary.

The Bureau of Standards, the Bureau of Chemistry, the Bureau of Mines and many other of the forty Government bureaus devoted to scientific research must, of course, be mentioned as factors in establishing our high position in research. In the estimation of our foreign friends they rank high. It often seems, as Mr. Everest has told us, that the funds are not as large as they should be, but the total appropriations for scientific work constitute a sum which is not inconsiderable, and I think we are probably doing more than any other Government. Other Governments have accepted our research results and these institutions have added much to our fame abroad as well as at 


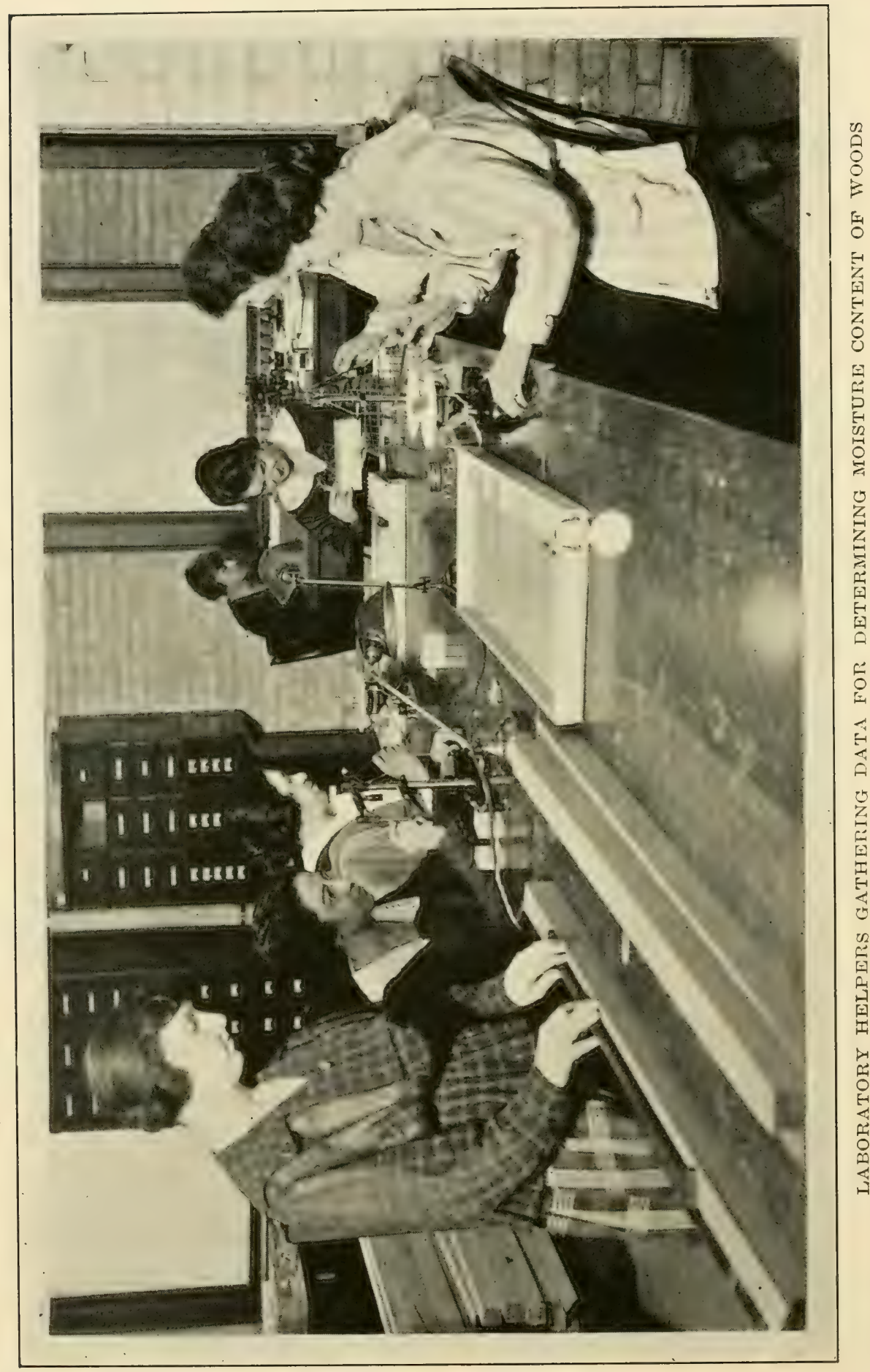


home. But we are not doing enough and have not enough money at our disposal.

The industrial fellowship plan of the Mellon Institute carries with it the idea of developing men for a particular field and at the same time solving the given problem. The success has been marked. All in all, we have reason to believe that we do stand high in industrial research. The present condition is very promising for eventual and undisputed leadership.

A list of nearly 300 industrial research laboratories has been published by the National Research Council and this does not include all in the United States. The scale on which certain of our investigations are handled is now a very hopeful sign. In the National Electric Lamp Association we find something like 2,000 men on development, work, 600 of them being highly trained technical men. The American Telephone and Telegraph Company have 1.300 giving their time to industrial research. In the Du Pont Company we find there are nearly as many engaged in industrial research, and in many other corporations large bodies of scientific men constantly at work trying to establish principles and gain knowledge that will improve process and product.

At one time in the rapidly changing conditions it was considered a sign of weakness to acknowledge that things were not as they ought to be and to spend money on scientific work.

Public serrice corporations who meet great difficulty in steadily increasing costs and fixed rates must turn to scientific work to find means of doing an increased amount of work more efficiently. As an example of the application of scientific research we can cite the longdistance telephone. When the problem was to talk across the continent there were two methods of attack. One was the derelopment of a special instrument with a loud transmitter for long distance work; the second was to find ways to use the instrument now installed. The second line of attack was followed out with the result that eventually the working radius of erery telephone was increased a thousand fold without changing the instrument, while the first method would have required the re-equipment of the entire telephone system of the country.

Research activities are increasing and industries are employing the very best research men they can possibly find. Today the cry is 
for better trained men rather than merely for more men who can work along scientific lines. This is another very hopeful sign. More and more fellowships have been established and the policy of establishing fellowships can be encouraged particularly where fundamental research in educational institutions is concerned.

The associations I have mentioned number something like twenty, at the present time. The National Canners' Association today is spending as much on one problem as the whole laboratory cost at the start. They have found industrial research a very well-paying investment.

There have been a number of new associations founded for cooperative research. A Plant Protection Institute has been formed to further the study of methods for controlling injurious insects and plant diseases.

The Petroleum Institute is another good example of the trend of the times, and I might also, in this connection, mention the support of scientific endeavor along fundamental lines by individuals who have heretofore directed their attention more toward commercial lines.

However, if you had not come here I might have better evidence that you need conversion to the cause of research. The fact that you are here to attend the celebration of the laboratory's great decade of industrial research should answer for you, for if you needed any argument to convert you to research, you would not be attending the birthday party.

Let us turn for a moment to a consideration of what we might do to strengthen our position as a world power in industrial research. I think first and foremost we need more fundamentally trained men and women who will step into and carry on industrial research. By fundamentally trained men and women. I mean those who really know the various sciences involved and who can fit into any need as do the white corpuscles of the body. As you know white corpuscles can become brain, tissue, bone, etc.- whatever the need may be at the time.

If industry is to get the most benefit from industrial research, I believe it to be essential that the laboratory be made just as important as the advertising or production department. I think such a department rightfully becomes a part of the organization, but that does not mean that such firms can not join in the cooperative solution of the fundamental questions of science. They can cooperate on such com- 
mon problems as fuel and smoke abatement. Improved working conditions and the use of the abnormal individual in industry are other good examples of cooperative work which the industries can undertake. The industries need to increase the number of unrestricted fellowships, and those industries that have profited through research should take steps to repay the debt they owe educational institutions. I do not believe in doing that simply by adding more fellowships, but the industries ought to make an allowance for their supervision.

We find that our Government laboratories are losing their best people on account of the inability to pay them what is necessary to relieve them of financial worry and to keep them in their employ. To discuss it further is useless; as Mark Twain said of the weather, "We talk about it a great deal, but nothing is done". It becomes rery discouraging in many universities that steps are not taken to properly increase the remuneration of the teacher's. 'This is one of the largest and greatest outstanding needs. Not all teachers can conduct research, but wherever one is found, he should be relieved of teaching and endowed so that his time can be spent on this work. Research should be fostered in educational institutions and the spirit of research encouraged by the establishment of research professorships and more fellowships.

The direct help of the industries to the government laboratories has been stressed. Adequate appropriations hare not been secured for the Forest Products Laboratory. The establishment of Advisory Committees who can consider problems from the riewpoint of the man who must eventually make the proper application of the data discorered should be encouraged. I believe funds for the direct support of the types of research in which each industry is concerned should come from the groups to be benefited and not from the Government alone. I am confident when industry pays directly to the sumport of well established research, it has more interest and is far more liable to apply the results obtained. Industry should be brought to realize its obligation to pay its debt to science by subscribing regularly a percentage of profits for the support of fundamental research. There are industries where people are still living on the profits upon investments in brains made by their ancestors, and they do not care to make any contributions themselves to industrial research for their descendants to nitilize. I am sure that many of the industries have no intention of 
being parasitic, but many of them must be brought to realize their dependence on science, its bearing on commerce and the desirability of doing the right thing to promote work upon fundamentals.

Another place where the industries can help is in the publication of bibliographies which are not properly cared for at present. There are many people who cheerfully support other forms of publication but find lists and bibliographies unattractive, even though they are essential for scientific work. There is always great difficulty in getting sufficient financial backing for such work, and yet there should be no delay in trying to find out from time to time what has been done and what is going on. The public as the ultimate benefactor of all this work clearly has its duty to perform in this connection.

That it is the public to which we must look is shown by the experience at the Brunner-Mond plant. The president and vice-president recently recommended that 100,000 pounds (sterling) be deroted to research in the universities, but the stockholders who had already received large dividends turned down this suggestion even though their business depends upon science for its existence and advancement.

I think that sort of thing comes from the lack of a proper understanding of science. For example, an advertisement appeared in a recent paper offering to pay a satisfactory cook $\$ 2.500$, and in the same service there was also an opportunity for an experienced chemist at $\$ 1,800$, and a laboratory assistant in pathology was offered $\$ 950$. I presume we must have good cooks, but it does seem that a trained scientist should be worth as much. The support of the government laboratories by the public at large is, of course, for the benefit of us all. Most of the speeches made in Congress appear to be designed for consumption by the people back home. If these people back home could only be convinced that we must have and spend money in supporting scientific work in their interests, as MIr. Ererest has outlined, I am sure it would be rapidly forthcoming and research could proceed on an adequate scale.

There are many sciences available for research that have not been called upon by industry. There is, for instance, the great group of biological sciences with which industry should become acquainted, and we can render service by introducing the two parties to their mutual advantage. We have the ability in this country to do the proper type of industrial research which will keep us in the lead. What can we 
do to bring about the improred conditions which I have attempted to describe?

First of all, we can work through our various scientific, technical and business organizations. We can work in many instances as individuals getting the story to others more effectively at times than can any organization.

All the great organizations in natural sciences are represented in the National Research Council which was introduced to you by Professor Mason last night. The Council is an opportunity for cooperation in science and a clearing house for research. The National Research Council is not a government organization, but enjoys the help of the Federal bureaus and scientists. It has a wide backing, and large funds have been obtained from certain foundations and industries which wish to help in carrying on this work of encouragement and stimulation. 'The money for' cooperative research must come from those who will be benefited, and as an example I would cite the support of the committee on Forestry by the Southern Pine Association. 'The Council has a deep interest in all phases of industries based on the forest and its products and invites your cooperation and your use of its facilities.

Whatever else the war has done for us, it seems to me that it has given people generally a little bit better insight into what science is, what it has done, and what it can do. WVe should preach research to educational industries, to indiriduals, to industries. We must get the support required for the research that will keep America in the very forefront.

Of all civilized countries we have the greatest responsibility in using our great reserves of natural resources, for they are almost world reserves. True conservation is based on intelligent use, and such use requires knowledge such as comes only from research.

The Forest Products Laboratory with its ten years of creditable work to recommend it can surely look forward with enthusiasm to the next decade during which time, as in the past, it will do its share in making America's place unquestionably in the lead. 


\section{Remarks of Mr. Foley Following Mr. Howe's Talk}

It must be a satisfaction to all of you to have heard that the lumber industry does not hesitate to take advantage of the help it can get from industrial research. 'Those of us who were privileged to be present when the plans of the Forest Products Laboratory were originally talked over can not help but look back with admiration upon the foresight of those who gave the incentive to this wonderful organization.

The lumbermen of the country have not been ready to acknowledge the usefulness of the foresters, as have been the wood-using industries, on account of the work done at the laboratory. Howerer, there has been no group of men who have more earnestly backed up the efforts of the Forest Products Laboratory and the Forest Service to get the money necessary to prosecute the investigations at Madison than have the lumbermen, and we are going to hear some of the problems of the lumber industry presented by a member of the committee on economics of the National Lumbermen's Association. It is very unfortunate that Mr. Scanlon who was scheduled to present this paper has been unable to come, but the committee on arrangements were exceedingly fortunate in getting in his stead, at the eleventh hour, a gentleman whose wide experience amply fits him to cover the subject very thoroughly. I take pleasure in introducing Mr. Gilchrist. 


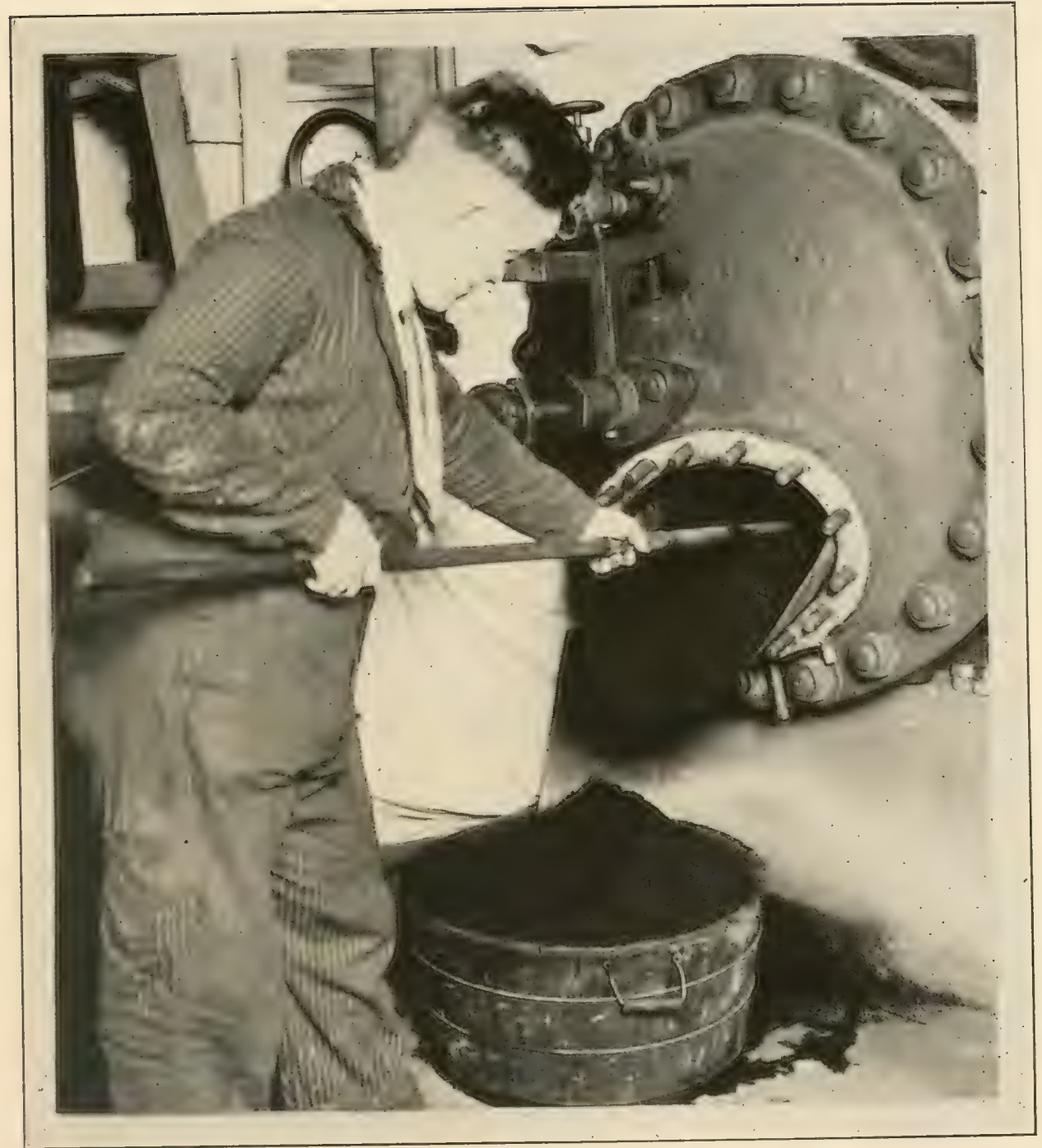

A MIRACLE OF CHEMISTRY-CONVERSION OF SAWDUST INTO STOCK FOOD 


\section{SOME PROBLEMS OF THE LUMBER INDUSTRY}

\section{W. A. Gilchrist, National Lumber Manufacturers' Association}

Ladies and Gentlemen:

This is a pleasure even though it is a substitute arrangement. You know Mr. Scanlan who was to speak is a prominent and successful Jumberman and an earnest believer in this activity, and it is my regret that he was not able to be here to present this problem in the masterful manner that he would.

I have heard some of my friends say "By all means say something complimentary about Madison". I heard yesterday our good friend Mr. Weiss, speak of the bathing facilities afforded in the vicinity. I have tried them all and I can say that after an early morning swim in this lake, one can undertake almost any obligation in connection with the problem confronting us.

Our industry is credited as being the largest consumer of the products of the forest. Our chief forester, Colonel Greeley, made the statement that the forest growth is but one-fourth of the normal or annual consumption.

I regret being compelled to make this statement, but it seems to be the consensus of public opinion that the average lumberman is opposed to a federal, or forestry policy. I hasten to correct this idea. We lumbermen are in sympathy with any reasonable forest policy. It is a broad problem which cannot be solved by the theoretical gentlemen, the practical ones, or the technical ones, but only by all of them working cooperatively.

I have every reason to believe that they can bring forth a policy handling this most important problem that will be worth our while. We must bear in mind that we need a conservative one, one that will. endure and one to which our posterity fifty years hence will say "Well done". That is our spirit, and that is what we want incorporated in that policy.

We lumbermen insist that there shall be provision made for the proper utilization of the natural stands of timber by economical means. We believe that the opportunity exists for the handling of that timber 
and without burdensome restrictions. Gentlemen, it affords me pleasure as a lumberman to make that statement, and I trust that the other lumbermen of my acquaintance appreciate the situation and will go forth and spread this gospel at all times.

I am a lumberman.

The definition of a lumberman as commonly understood by the public is one who maliciously and wantonly destroys the forests.

They are presumed to be a rough set of men; men without character.

Being frontier men, naturally they are presumed to be devoid of the niceties that go to make life worth living, an uneducated class. Their mathematics are presumed to be sadly neglected. Fren as much as in the case of my early acquaintance, Capt. Jack Downer, a master of a lake lumber cargo steamer. In the early days of the lumber industry, in the vicinity of the Great Lakes, small steamers were used to transport the cargoes of lumber from point of manufacture to the lower lake ports, the points of consumption. Upon departure from the port of loading, a document was handed to the ship's master indicating the quantity of lumber and the freight rate per thousand feet expressed in shillings. The cargo upon this particular royage consisted of 392.782 feet of lumber at a rate of 13 shillings. Captain Jack's early education had been much neglected. The period of the voyage was three days. In order to determine the amount of freight money to be collected. the captain spent all of the three days in a vain effort to determine the sum. No two computations resulted alike, and as the royage was nearing completion, with the table in front of him corered with bits of paper in his effort to arrive at this result, in exasperation Captain Jack beat the table forcibly with his fist and exclaimed. "Why in h-l don't they make these rates $\$ 1.00$ or $\$ 2.00$ so that a man can figure them".

Wastes were excessive in the harvesting of the forest, the mechanical appliances were likewise destructive and wasteful about the mills. But, gentlemen, bear in mind that the lumber business, no different from any other commercial industry, is an economic problem, and failure confronts it if pursued in any other manner.

Within my memory, the early lumberman was unable to indulge himself in any of the modern luxuries-his food was of a substantial character, but consisted principally of beans and salt pork-for the 
reason that the profits were such as did not permit of more. The early, successful lumberman was a student of economics in his own way, and those who were not failed. The successful ones interpreted the term, "merchantable"-that which could be harvested at a profit-accurately, and there are many instances of financial disaster of those who failed to comprehend.

The term "lumber king" and "lumber baron" were earned only by those who deserved it, and came only to those with foresight, wisdom, and above all, with the ability to discern the economics of the problem.

'The term, "merchantable", is a variable one in the classification of either timber or its products. It differs at this date from that of thirty years ago ; it differs today as to localities; for instance, low quality timber classed as mechantable in the state of $\mathrm{New}$ York would likely be classed as being below that term in the states of 'Texas or California, namely, unprofitable to harvest. Therefore, care must be taken in discussing problems of our industry, as they are purely problems of economics.

Other industries possess the same and similar problems. Gold mining in the West was no exception. Witness the tailing piles of these early mines being worked by Chinamen. The famous Black Hill gold mining district of the Dakotas, a low valued ore for years, wasted a value of eighty cents per ton in tailing, when their raw material was presumed to carry but some $\$ 2.30$, as it was more economical to return to the raw material supply than attempt too great an extraction. The sugar producer permits a waste of two to four per cent of sucrose and replenishes with raw material.

I retired from the lumber business and for some years engaged in the production of sugar. In one employment I had a preceptor, a gentleman trained in the European school of economics, a most competent sugar man. One day in discussing our problems, he stated, "Gilchrist, I was 15 years in learning American methods of sugar manufacture". The explanation was based upon low European wages and high cost of raw material compared to high American wages and low cost of raw material. It is a simple problem in economics.

A number of years ago, when this wonderful Forest Service was organized, young men representing this institution appeared before us lumbermen at our conventions. These young men upon all occa- 
sions were most affable, and they frequently addressed us. We indulged them. We were good natured. Some of the statements made by these young college men-always good looking and enthusiastic chaps-we poor lumbermen engaged in wallering logs from the swamps envied them, for sure they possessed a degree from some university as foresters, and, therefore, we solicited their advice-butsome of the proposals made by these young men were interesting at least-but blamed impractical. Frequently they indulged in predictions as to the financial outcome of our industry; on some occasions they indulged in comments indicating that portions of our industry could fairly be classified as profiteering were we to advance the price of our commodity.

I am free to admit that many lumbermen considered the comments of some of these young foresters as right impertinent. I wish some of these young men, after an experience of some fifteen years, would review their notes of these addresses, and, of course to themselves, conclude what changes they would make in the advice offered at that particular time.

The evolution was and is as my sugar friend explained-American industry can not be conducted upon European principles. The forester's training is by European instruction or its influence upon such instruction. Required-American instructions applicable to American industry.

I offer a ray of hope. The modern American lumberman while a frontierman of necessity, for timber is only available in such vicinities in the main, has himself dereloped. At least 25 per cent and possibly to per cent of the present generation of lumbermen of my acquaintance who are directing a modern lumber business are college men. While such training is not of prime necessity to the success of the lumber business, it indicates a type of man whose brain is presumed to have been afforded an opportunity to develop. 'Therefore, these men, usually being ones of influence, should be more receptive to problems required in the advance of our industry.

Certain activities of this wonderful institution, the Forest Products Laboratory, are attracting the earnest attention of members of our industry. Being engaged in the commercial side of the lumber business, I hear comments of the most favorable nature, that I fear do not come to the ears of those sincere men engaged in directing this 
activity. The packing box investigation is of inestimable value. The problems associated with the seasoning of lumber are so far reaching that it in itself is a subject for discussion that would engage attention indefinitely. However, these are problems of the products of the forests only.

There is another field of activity that requires exploitation. It has to do with the prevention of wastes and the use of the unpreventable wastes-if there be any. Many lumbermen believe that the policy of harresting the mature stands of timber, by the most economical means, at this time or as soon as possible, is proper. The imposition of burdensome restrictions that retard such a policy we believe to be uneconomical.

To a degree this is a mechanical problem. Our industry has been classed, and rightfully so, as a mechanically progressive industry. The development has been directed along the lines of labor-saving devices. The success of such development is observed in the sawmill proper, where particularly laborious tasks have been eliminated. However, there remain certain tasks which are particularly laborious in certain portions of our operations, and I will touch upon some of these later.

We have, however, as an industry, neglected mechanical development which tends to reduce waste.

It is indicated by surveys of some specific branches of lumber production that about one-third of the cubic contents of the tree ultimately reaches the form of lumber. Some seven per cent of loss occurs in the form of stumps. Another serenteen per cent occurs in the mechanical losses of sawdust and shavings. These three items of losses are worthy of attack.

A survey of a yellow pine operation indicated that there existed a preventable loss of an amount of 450 feet per acre, or approximately two per cent of the original stand of timber on this area. This was preventable by severing the stump at a line six inches above the ground level. A premium was offered the woodsmen who did this cutting to encourage them to reduce this stump height, explaining to them that they too were indirectly interested in the perpetuation of the life of the sawmill institution, and by so doing an additional amount of some 300,000 feet of timber might be removed from each section of land cut. 'This method of cutting is most laborious. Men must crouch in an awkward position. Many of the men objected, in spite of the induce- 
ments offered. I pay tribute to the proprietor of this business who perfected this seemingly slight economy, for the obstacles were many.

There exists no mechanism that accomplishes this task to perfection, the common and principal fault being a lack of portability of such machines as are now available, due to excess weight. The task that confronts us is one of mere engineering - to establish rules covering the creation of suitable mechanism.

Who better can accomplish this than an engineer cooperating with the woodsmen?

Funds in limited quantities are available for the establishment of a piece of mechanism to assist in the inquiry into the possibilities of circular saws. This is being conducted by the National Lumber Manufacturers' Association. 'The excessive saw kerf in the apparatus used in certain required operations about the sawmill is well known. A sawmill operation is a commercial institution and can poorly serve as an experimental laboratory. It is common knowledge that certain recently developed alloys in steel have solved many manufacturing problems in the metal tool trades-in our own industry in the planing mill. 'The planing mill equipment of ten or twelve years ago is now obsolete. The manufacturers of sars have been limited in their possible experiment and development, for present sawmill equipment prohibited experimenting. 'The factor of speeds of cutting points, an important clement in production. was defined; the human element likewise is inrolved, having to do with the care and sharpening (filing) of saws.

The saw manufacturer is hedged in by the steel manufacturer, the sawmill machinery builder, and the sawmill operator. Without the cooperation of all of these, no progress can be made.

It is proposed to install equipment for experimental purposes of a type where speeds are available to a degree that does not now exist in commercial mechanism. The saw manufacturer, the steel producer, the metallurgist are invited to investigate and cooperate in these developments. They are responding with a will, and so the sawmill machinery builder and the lumber producer hope for progress.

It is to be desired that the progress, for the present at least is to be in the direction of reclaiming some of these losses attributed to sawdust, and not in increased capacities. This problem is merely one of economics. It must be made a profitable one. Therefore, with this in mind, a survey of such losses, their allocations, and whether they are 
of a preventable nature should be made. This should be followed by a later survey to determine if they still exist after the introduction of mechanism that is to be developed to utilize them in some profitable manner.

This is a momentous problem and one that manufacturing lumbermen and stumpage owners should pay for, for they alone benefit directly thereby. I submit to you gentlemen this statement of conditions, and ask for your sincere assistance in support of an activity to spread this information to the lumbermen themselves, for "If there be any criticism to be passed upon the lumbermen it is that they have kept their achievements too much to themselves. They have been satisfied to make a large amount of worthless land extremely valuable, and have not taken the trouble to explain their work to the people at large. This is a period of great publicity and large advertising, and the lumber industry must realize this fact in order to keep abreast of the times". This quotation, substituting the name of lumbermen for iron ore miners, is from a poblic document treating of iron ore deposits in the state of Minnesota, and indicates the pleasant relations that exist between commercial and technical branches of this particular industry. and is a sentiment that I wish might be encouraged and intensified between the practical lumbermen and the technical division of the forest products industry. 
APPENDIX 



\section{REGISTRATION LIST}

Forest Products Laboratory Decennial Celebration, Madison, Wisconsin, July 22 and 23, 1920

Ackerman, E. D., Waterproof Adhesives Co., Milwaukee, Wis. Adams, F. R., Pacific Lumber Co., Chicago, Ill. Alexander, John E., Nekoosa-Edwards Paper Co., Port Edwards, Wis.

Alexander, John E., Mrs., Port Edwards, Wis.

Alexander, L. M., Pres., Nekoosa-Edwards Paper Co., Port Edwards, Wis.

Alexander, L. M., Mrs., Port Edwards, Wis.

Altman, N. A., J. W. Butler Paper Co., Chicago, Ill.

Anderson, W. R., Publisher, "Packages", Milwaukee, Wis.

Angier, F. J.. Baltimore \& Ohio R. R., Baltimore, Md.

Babbitt, W. C., Gen. Sec'y., Natl. Assn. of Wood Turners, South Bend, Ind.

Baker, John S., Baker Mfg. Co., Evansville, Wis.

Baker, Wm. B., Secy., Nat'l Assn. Chair MIfgrs., Chicago, Ill.

Barr, H. G., J. I. Case Co., Racine, Wis.

Barth, Kurt, Barrett Co., Chicago, Ill.

Bartle, F. C., Mrs., Madison, Wis.

Bartle, Gladys, Madison, Wis.

Bartle, Vernetta, Madison, Wis.

Bauer, Carl, Doesch \& Bauer Co., Chicago, Ill.

Belknap, G. F., Aeroshade Co., Waukesha, Wis.

Birge, E. A., Pres., University of Wisconsin, Madison, Wis.

Bitting, A. W.. Dr., Glass Containers Assn., Chicago, Ill.

Blackburn, Robert, Wilbur Lumber Co., Milwaukee, Wis.

Blanco, J. P., San Juan, Porto Rico.

Boehme, E. E., International Creosoting Co., Galveston, Tex.

Boettcher, Albert E., Milwaukee Chair Co., Milwaukee, Wis. 
Bolz, H. C., Bolz Cooperage Corp., St. Louis, Mo.

Bolz, P. T., Pres., Bolz Cooperage Corp., St. Louis, Mo.

Brandenburg, O. D., Pres., Democrat Printing Co.; Mng. Editor, Madison Democrat, Madison, Wis.

Brantingham, C. S., Emerson-Brantingham Co., Rockford, Ill.

Brantingham, C. S., Mrs., Rockford, Ill.

Bray, Chas. P., Baggage Mfg. Assn., Conway Bldg., Chicago, Ill.

Bremer, G. B., J. J. Fitıpatrick Lumber Co., Madison. WV is.

Brown, H. H., Pejepscott Paper Co., Brunswick, Maine.

Bryant, R. C., Yale University, New Haven, Conn.

Buckstaff, R. N., Buckstaff Co., Oshkosh, Wis.

Buehler, Walter, Barrett Co., New York, N. Y.

Burgess, C. F., Pres., C. F. Burgess Laboratory, Madison, Wis.

Burgess, Mrs. C. F., Madison, Wis.

Card, J. B., Central Creosoting Co., Chicago, Ill.

Caswell, A. B., Pfister \& Vogel Leather Co., Milwaukee, Wis.

Chapman, Arnold, International Alcohol Corp., New York, N. Y.

Cherner, E. G.. University of Minnesota. St. Paul, Minn. (Chief, Division of Forestry).

Clark. Allen W., American Car \& Foundrỵ Co., Jeffersonville, Ind. Clark, Mrs. Allen W., Jeffersonville, Ind.

Clark, W. A., Chief Engr., Duluth \& Superior R. R., Duluth, Minn. Clausen, F. H., Van Brunt Mfg. Co., Horicon, Wis.

Compton, Wilson, Sec.-Mgr., National Lumber Mfgrs. Assn., Chicago, Ill.

Cone, A. B., "Lumber World Review", Chicago, Ill.

Conrad, Elizabeth, Madison, Wis.

Conzet, G. M., Fire Inspector, State of Minnesota. St. Paul, Minn.

Cooper, R. F., Spanish River Pulp \& Paper Co., Soo, Ontario.

Cornell, Herbert W., Milwaukee, Wis.

Corry, W. J.. Foster Creek Lumber \& Mfg. Co., Madison, Wis.

Cox, W. T., State Forester, St. Paul, Minn.

Coye, C. W., Industrial Specialist, Grand Rapids, Mich.

Crawford, Carl G., American Creosoting Co., Louisville, Ky.

Curtis, C. E., IVisconsin Cabinet \& Panel Co., New London, Wis.

Cushman, R. E., Northwestern Timber Co., Mendota, Ill. 
Dahl, R. D., Sherlin, Carpenter \& Clarke, Minneapolis, Minn.

Dana, S. T., U. S. Forest Service, Washington, D. C.

Davies, Luther, Oshkosh, Wis. (Lumberman).

Defebaugh, Carl W., "American Lumberman", Chicago. Ill.

Demartini, F., Sec., Baggage Mfgr. Assn., Conway Bldg., Chicago, Ill.

Dudley, J. E., Madison, Wis.

Dudley, J. E., Mrs., Madison, Wis.

Dumond, Louis A., Chicago Assn. of Commerce, Chicago, Ill.

Dunlap, Frederick, C'niversity of Missouri, Columbia, Mo.

Esau, Ralph, Barrett Co., Chicago, Ill.

Everest, D. C., Secr. and Gen. Mgrr., Marathon Paper Co., Wausau, Wis.

Fitzpatrick, J. J., J. J. Fitzpatrick Lumber Co., Madison. Wis.

Foler, John, Pennsylrania R. R. Co., Philadelphia, Pa.

Frantz, S. G., Crossett Lumber Co., Crossett, Ark.

Fredrickson, E. A., Virginia \& Rainy Lake Co., Minneapolis, Minn.

Fredrickson, S. D., A. D. \& J. V. Fredrickson Lumber Co., Madison,

Wis.

Frick, O. H., Milwaukee, Wis.

Fuller, L. E.. Editor, "The Lumber \& Veneer Consumers", Chicago, III.

Furlong, Edward, "Packages", Milwaukee, Wis.

Gilchrist, W. A., National Lumber Mfgrs. Assn., Chicago. Ill.

Goodman, R. B.. R. B. Goodman Lbr. Co., Marinette. Wis.

Goslines, C. E., D. L. \& W. Railroad, Paterson, N. J.

Grady, W. H., American Creosoting Co., Louisville, Ky.

Graves, L. W., J. P. Devine Co., Buffalo, N. Y.

Greeler. W. B., Forester. L. S. Forest Serrice, Washington, D. C.

Green, George R.. Pennsylvania State College of Forestry, State College, $\mathrm{Pa}$.

Greider, C. E., B. F. Sturtevant Co., Chicago, Ill.

Greider, C E., Mrs., Chicago, Ill.

Grow, J. H., Allis-Chalmers دIfg. Co., Milwaukee, Wis. 
Gullickson, O., Pres., Chicago Furniture Assn.; also Churchill Cabinet Co., Chicago, Ill.

Gullickson, S., Churchill Cabinet Co., Chicago, Ill.

Hamilton, C. L., W eyerhauser Forest Products Co., St. Paul, Minn.

Hanson, Adolph, J. I. Case Co., Racine, Wis.

Harder, Geo. N., Rib Lake Lumber Co., Rib Lake, Wis.

Harrington, C. L., Wisconsin Conservation Comm., Madison, Wis.

Hemingway, E. E., Wisconsin 'Timber \& Land Co., Mattoon, Wis.

Hendricks, Mr., Madison, Wis.

Henning, S. B., Anderson-Tully Co., Memphis, Tenn.

Henry, A. T., Morgan Co., Oshkosh, Wis.

Ifenry, G. E., Editor, "Barrel \& Box", Chicago, Ill.

Hickey, E. H., Sec.-'Treas., "Packages", Milwaukee, Wis.

Hirt, J. F., Vice-Pres., Management Service Co., Chicago, Ill.

Hogue, C. J., West Coast Lumbermans' Assn.. New York City.

Holbrook, L. W., Asst. Treas.. Sherlin Co., Minneapolis, Minn.

Holderness, Robert M., Bain Wagon Co., Kenosha, Wis.

Honnell, F. H., Wilson \& Co., Chicago, Ill.

Horn, S. F., Editor, "Southern Lumberman", Nashville, Tenn.

Hosford, Roger S., American 'Tel. \& Tel. Co., New York, N. Y.

Hosmer, Ralph S., Dept. of Forestry, Cornell Univ., Ithaca, N. Y.

How, H. W., J. P. Devine Co., Buffalo, N. Y.

Howard, H. C.. National Assn. of Box Mfgrs., Chicago, Ill.

Howe, H. E.. National Research Council, Washington, D. C.

Howson, E. T.. "Railway Maintenance Engineer". Chicago, Ill.

Hort, H. B., Supt., 'Timber Preserving Plant, B. R. \& P. Railroad, Bradford, Pa.

Hubbard, C. W., Pres., Northwestern Timber Co., Mendota, Ill.

Hurd, N. L., Mid-West Box Co., Chicago, Ill.

Imrie, J. E., Cutler Desk Co., Buffalo, N. Y.

Imrie, J. E., Mrs., Buffalo, N. Y.

Jackson, Carl D., Railroad Commission, Madison, Wis.

Johnson. B. A., Editor. "Lumber World Review", Chicago, Ill.

Jones, B. W., Lawyer, Madison, Wis.

Jones, Mrs. B. W., Madison, Wis. 
Jones, G. W., Appleton, Wis.

Jones, J. E., Southern Pine Assn., New Orleans, La.

Jones, T. E., Athletic Director, Univ. of Wisconsin, Madison, Wis.

Joyce, A. R., Joyce-Watkins Co., Chicago, Ill.

Judd, Roy, Oxford, Wis.

Karges, E. F., Karges Furniture Co., Evansville, Ind.

Keig, J. R., Treating Inspector, A. T. \& S. F. R. R., Chicago, Ill.

Keith, L. P., National Lbr. Mfgrs. Assn., Chicago, Ill.

Kelly, T. E., Madison, Wis.

Keyser, Henry, Western Grip \& Trunk Co., Milwaukee, Wis.

Kimberly, H. H., Morgan Co., Oshkosh, Wis.

Kittridge, J. Jr., Forest Service, Washington, D. C.

Knowlton, H. A., Reed College, Portland, Ore.

Kraber, G. L., Turbine Air Tool Co., Cleveland, Ohio.

Krafft, Y. WV., Sec., Associated Cooperage Industries of America, St. Louis, Mo.

Krenz, M. B., Mrs., Chicago, Ill.

Lamb, Geo. N., American Walnut Mfgres. Assn., Chicago, Ill.

Landstrom, O. E., Rockford Veneer \& Panel Co., Rockford, Ill.

Leicester, W. F., Casein Glue Manufacturing Co., Chicago, Ill.

Lemke, O. C., Underwood Veneer Co., Wausau, Wis.

Leopold. Fredrick, Leopold Desk Co., Burlington, Iowa.

Lester. S. A., Doyon \& Rarne Lumber Co.. Madison, Wis.

Long. H. A., Automotive Wood Wheel Mfgrs. Assn., Chicago, Ill.

Lorejoy, P. S., University of Michigan, Ann Arbor, Mich.

Lunenschloss, I. I... Foster Creek Lhr. \& IIfg. Co., Madison, Wis.

MacLean, M. M.. Chief Chemist, Dodge Mffg. Co., Mishawaka, Wis. Mallen, H., H. Z. Mallen Co., Chicago, Ill.

Mandenberg, E. C., Barrett Co., Chicago, Ill.

Marschall, A. J., Marschall Dairy Laboratory, Madison, Wis.

Martin, Gus, Doesch \& Bauer Co., Chicago, Ill.

Mason, Max, University of Wisconsin, Madison, Wis.

Mason, Mrs. Max, Madison, Wis.

Maurer, E. R., University of Wisconsin, Madison, Wis.

Mauthe, Wm., Casket Mfg. Assn. of the U. S., Fond du Lac, Wis. 
Maxwell, Hu, "American Lumberman", Chicago, Ill.

McCaffrey, M. E., University of Wisconsin, Madison, Wis.

McCullough, E. W., Chamber of Commerce of the U. S. A., Washington, D. C.

McKeever, Francis H., 4-Ones Wirebound Box Mfgrs. Assn., Chicago, Ill.

McLarsen, A., Alfred Decker \& Cohn, Chicago, Ill.

McLoughlin, J. M., Gen. Mgr., Wisconsin Cabinet \& Panel Co., New London, Wis.

McNair, C. J., Jr., Northwest Paper Co., Cloquet, Minn.

Mead, Geo. W., Pres., Consolidated Water Power \& Paper Co., Grand Rapids, Wis.

Meeker, E. W., Editor, "Hardwood Record", Chicago, Ill.

Meeker, E. W., Mrs., Chicago, Ill.

Merritt, L. G., Merritt Engineering \& Sales Co., Lockport, N. Y.

Merritt, L. G., Mrs., Lockport, N. Y.

Miller, R. B., State Forester, Urbana, Ill.

Moak, E. R., Managing Editor, Wisconsin State Journal, Madison, Wis.

Moon, Franklin, Syracuse University, Syracuse, N. Y.

Moroney, Robert E., Dallas, Texas.

Morris, Fred H., Union Cedar Co., Toledo, Ohio.

Morris, Leslie, Chicago Mill \& Lumber Co., Chicago, Ill.

Mowry, Don E., Sec., Madison Assn. of Commerce, Madison, Wis.

Nichol, F. M., Turbine Air Tool Co., Cleveland, Ohio.

Norberg, Elizabeth, Portland, Ore.

Osborne, A. L., Oshkosh, Wis. (Nat'l Lbr. Mfgres. Assn.).

Paul, C. E.. C'onstruction Engineer, National Lbr. IIfgrs. Assn., Chicago, Ill.

Peavy, Geo. W., Dean, School of Forestry, Oregon Agric. College, Corvallis, Ore.

Peery, Thomas D., Grand Rapids Veneer Works, Grand Rapids, Mich.

Peters, T. G., Forest Service, Washington, D. C. 
Pettibone, G. D., National Assn. of Cpholstered Furniture Mfgrs., Chicago, Ill.

Philipp. E. L., Governor, Commonwealth of Wisconsin, Madison, Wis.

Pratt, C. A., Tacoma, Wash.

Prien. J. C., Passenger Agent, C., M. \& St. P. Ry., Madison, Wis. Pullen, King H., Southern Pine Assn., New Orleans, La.

Quinn, D. L., Chicago 1 Iill \& Lumber C'o., Chicago, Ill. Quinn, D. L., Mrs., Chicago, Ill.

Quisna, C. L., Weverhauser Forest Products, St. Paul, Minn.

Padsch, R. M., Thilmany Pulp \& Paper Co., Kaukauna, Wis. Rayne, Fred W., Doyon \& Rayne Lumber Co., Madison, Wis. Redman, Kenneth, B. F. Sturterant Co., Chicago, Ill.

Reiff, E.. Casket MIfgrs. Assn. of of America, St. Paul, Minn.

Rhodes, E. R., Standard Furniture Co., Herkimer, N. Y.

Rhodes, J. E., Southern Pine Assn. New Orleans, La.

Rice, Claude H., Milwaukee Chair Co., Milwaukee, Wis.

Robinson, B. B., Hayes Iona Co., Iona, Mich.

Sackett, H. S., Asst. Purchasing Agent, C'hi., Milw. \& St. Paul, C'hicago, Ill.

Salt, W. S., Container Club, Chicago, Ill.

Sameit, H. J., Acting Sec., National Implement \& Vehicle Assn., Chicago, Ill.

Sassey, F. L., J. J. Fitzpatrick Lumber Co.. Madison, Wis.

Schmid, R. V., Kimberley-Clarke Co., Neenah, Wis.

Schmidt, H., Elgin Butter Tub Co., Elgin, Ill.

Schorger, A. W., Chemist, C. F. Burgess Laboratories, Madison, Wis.

Schorger, Mrs. A. W., Madison, Wis.

Schuette, Menry, University of Wisconsin, Madison, Wis.

Schuh, J. P., Pres., Schuh-Mason Lumber Co., Cairo, Ill.

Schuh, Julius, Mrs., Cairo, Ill.

Schuh, Margaret, Cairo, Ill.

Schulte. W. B., C. F. Burgess Lahoratories. Madison, Wis.

Schultz, Marie, Chicago, Ill. 
Schultz, Otto, Pres., National Piano Mfgrs. Assn. of America, Chicago, Ill.

Schultz, Otto, Jr., Chicago, Ill.

Sensenbrenner, J. Leslie, Kimberly-Clarke Co., Neenah, Wis.

Shelly, W. P., Shevlin, Carpenter \& Clarke Co., Minneapolis, Minn.

Sliger, O., Mengel Co., Louisville, Ky.

Slocum, Bert, Madison, Wis.

Smith, Kent, Shevlin, Carpenter \& Clarke Co., Minneapolis, Minn.

Smith, Lowry, Asst. Division Engineer, Northern Pacific R. R., St.

Paul, Minn.

Smith, M. W., Duiron Co., Dayton, Ohio.

Snider, Margaret, Madison, Wis.

Sterling, E. D., Yawkey-Bissell Lumber Co., White Lake, Wis.

Sterling, Elsie, White Lake, Wis.

Stocking, E. J., Central Creosoting Co., Chicago, Ill.

Stuart, M. H., National Basket \& Fruit Packing Mfgrs. Assn., St. Joseph, Mich.

Swan, O. T., Northern Hemlock \& Hardwood Assn., Oshkosh, Wis.

Swan, O. T., Mrs., Oshkosh, Wis.

Tamlin, B. C., National Assn. of Corrugated Fibre Box MIfgrs. Assn., Chicago, Ill.

'Taylor, C. M., Pennsylvania \& Reading R. R., Port Reading, N. J.

Taylor, Hugh K., Editor, "Lumber", St. Louis, Mo.

Taylor, Lucy S., Madison, Wis.

Taylor, S. D., Perkins Glue Co., South Bend, Ind.

'Taylor, W. D., Mrs., Madison, Wis.

Thielens, A. B., Studebaker Corp., South Bend, Ind.

Thomas, Leon I., Editor, "Factory", Chicago, Ill.

Thompson, P. MI., Science Master, Windsor Collegiate College, Windsor, Ontario.

Thorkelson, H. J., Business Mgr.. Univ. of Wisconsin, Madison, Wis. Tiemann, J. H., Mrs., Madison, Wis.

Tuttle, L. S., Minneapolis, Minn. (Wholesale Lumber Dealer).

Van Camp, E. E., American Hardwood Mfgrs. Assn., Memphis, Tenn.

Van Camp, E. E., Mrs., Memphis, Tenn. 
Vilas, Dr. C. H., Board of Regents, L'niversity of Wisconsin, Madison, Wis.

Vogel, Fred A., Pfister \& Vogel Co., Milwaukee Vis., Representing "Tanners Council."

Waldron, Eloise, Fargo, North Dakota.

Waldron, M. B., Agric. College of North Dakota, Fargo, N. D.

Ward, A. F., National Assn. Basket \& Fruit Package Mfgrs. Assn., Plymouth, Ind.

Weiss, H. F., C. F. Burgess Laboratories, Madison, Wis.

Weiss, H. F., Mrs., Madison, Wis.

Werbelo, F. C., Shawano Box Co., Shawano, Wis.

TVetmore, R. W., Sec'y and 'Treas., Shevlin Co., Minneapolis, Minn. Whearr, Geo. H., Hartmann Trunk Co.. Racine Wis., Representing Baggage Mfgrs. Assn.

Wheaton. WV. R., Manager, Pulpwood Co., Appleton, Wis.

Wheaton, W. R., Mrs., Appleton, Wis.

Wheeler, W. C., Student, University of Wisconsin, Madison, WVis.

White, Thos. A. Pres. Crane \& MacגIahon, Inc., St. Mary's, Ohio \& St. Mary's Wheel \& Spoke Co., St. Mary's, Ohio.

TVindoes, Ralph F.. Fditor, "Furniture Mfgr. \& Artisan", Grand Rapids, Mich.

Winkenwerder. Hugo. University of Washington, Seattle, Wash. Woodford, E. G.. Yawkey-Bissell Lumber Co., White Lake, Wis. Woodford, E. G., Mrs., White Lake, Wis.

Wright, Dorothy, Madison, Wis.

Wulpi, M., Plywood Manufacturers' Assn., Chicago, Ill.

Tager, Louis, Engineer M. of Way, Northern Pacific R. R., St. Paul, Minn.

Yager, Mrs., St. Paul, Minn.

Young, Edward J., Foster Creek Lbr. \& Mfg. Co.. Madison, Wis.

Young. Howard S., National Basket \& Fruit Pkg. Mfgr. Assn., Indianapolis, Ind.

Zelmer, Geo. R., Morgan Co., Oshkosh, Wis.

Zelmer, Mr., Jr., Oshkosh, Wis.

Zoelle, F. J., Passenger Agent, C. \& N. W. Ry., Madison, Wis. 



\section{FORMER STAFF MEMBERS}

\section{Forest Products Laboratory}

Left the laboratory prior to July 1, 1920.

S. F. Acree

Shirley W. Allen

Charles 'T'. Barnum

Francis M. Bond

H. Stanley Bristol

Frank E. Bonner

Samuel Butterman

James L. Brownlee
Manager,

International Chemical Products Co.

Eureka, Montana.

Forest Supervisor,

Angeles National Forest

Los Angeles, California.

Wilkesbarre, Pennsylvania.

General Manager, Corticelli Silk Mills,

Florence, Massachusetts.

Department Manager, Baeder-Adamson Company, Philadelphia, Pennsylvania

Assistant Chief Engineer,

U. S. Forest Service,

Washington, D. C.

Proprietor,

Monarch Textile Company,

Chicago, Illinois.

Assistant District Engineer,

U. S. Forest Service,

Denver, Colorado. 
Horace 'T. Burgess

Waynesville, Ohio.

McGarvey Cline

Vice-President, Florida Pine Company,

Consulting Engineer,

Consolidated Naval Stores Co., Jacksonville, Florida.

Robert E. Cooper

Resident Engineer-Soo Mill, Spanish River Pulp \& Paper Co., Sault Ste. Marie, Ontario.

Ollison Craig

Research Engineer,

Underfeed Stoker Company,

Detroit, Michigan.

Richard A. Colgan

Forester,

Diamond Match Co.,

Chico, Cal.

Rufus Crane

Assistant Professor of Engineering,

Ohio Wesleyan University,

Deleware, Ohio

Clarence W. Coye

'Technical Expert, W. H. Coye Organization,

Grand Rapids, Michigan.

C. K. Cooperrider

Grazing Examiner, U. S. Forest Service, Albuquerque, New Mexico.

Fredrick Dunlap

Consulting Forester, Columbia, Missouri. 
Edward P. Devlin

Arthur J. DeSmidt

Joseph D. Deihl

Walter C. Daley

Armin Elmendorf

Nils B. Eckho

Leroy P. Elliott

Ernest D. Fahlberg

Jenness B. Frear
Chemist,

Pitcaim Varnish Company,

Milwaukee, Wisconsin.

Confectionery Manufacturer, Oshkosh, Wisconsin.

Vice-Principal,

Boys' Technical High School,

Milwaukee, Wisconsin.

Central Waxed Paper Company,

Chicago, Illinois.

Consulting Engineer,

Haskelite Manufacturing Corporation, Chicago, Illinois.

In Charge Kiln Drying Research, Forest Department,

Government of South Africa, Pretoria, South Africa.

Dean, Vocational Courses, Bradley Polytechnic Institute, Peoria, Illinois.

Assistant Professor,

Department of Chemical Engineering,

University of Wisconsin,

Madison, Wisconsin.

Specialist in Boxing and Crating, American Radiator Company, Buffalo, New York. 
Clark W. Gould

Frank J. Hallauer

S. B. Henning

Henry J. Hegel

M. H. Hostman

Eugene F. Horn

Jacob M. Johlin, Jr.

John A. Jess

Don P. Johnston
Forest Examiner,

Office of Products,

U. S. Forest Service,

Portland, Oregon.

Edward J. Young, Lumberman,

Madison, Wisconsin.

Technical Advisor on Gluing Problems, Milwaukee, Wisconsin.

In Charge Collection and Claim Divisions,

General Electric Company,

Philadelphia, Pennsylvania.

Pacific Coast Representative, In Charge of Industrial Sales and

Engineering,

American Radiator Company,

San Francisco, California.

Linha Paulista,

Estado de Sao Paulo, Brazil.

Syracuse, University,

Syracuse, New York.

Consulting Mining Engineer, Jasper Park Collieries, Limited, Royal Mineral Association, Duluth, Minnesota.

General Manager, Johnston-McNeil Company,

Naval Stores.

Okechobee, Florida. 
J. Norman Jensen

Willam H. Kempfer

Simon Kirsch

Fredrick W. Kressman

Harry N. Knowlton

Carl A. Kupfer

Jesse B. Kommers

James C. Lawrence

Joseph P. Mehlig
Architectural Engineer,

175 West Jackson Boulevard,

Chicago, Illinois.

Cattle Rancher,

Deer Park, Florida.

Botanical Laboratory,

McGill University,

Montreal, Canada.

Manager,

Continental 'Turpentine and Rosin Company,

Laurel, Mississippi.

Boxing and Packing Specialist, General Electric Company, Schenectady, New York.

California Representative, North Coast Dry Kiln Company, Berkeley, California.

Associate Professor of Mechanics,

University of Wisconsin,

Madison, Wisconsin.

President,

American Chemical Machinery Co., Chester, Pennsylvania.

University of Wyoming,

Laramie, Wyoming. 
Leslie R. Morris

Fingineer,

Chicago Mill and Lumber Company,

Chicago, Illinois.

William W. Morris

Consulting Forester and Landscape Architect,

Pine Bluff, Arkansas.

Teodulo J. Medicielo

Road Construction Engineer,

City of 'Tacloban,

Leyte, Philippine Islands.

Samuel Morrell

Chief Structural Engineer, Sanitary District of Chicago,

Chicago, Illinois.

Edward R. Maurer

Professor of Mechanics,

College of Engineering,

University of Wisconsin,

Madison, Wisconsin.

George C. McNaughton Plant Superintendent,

The Mead Fibre Company,

Kingsport, Tennessee.

Andrew H. McKenzie Kansas City Fibre Company, Kansas City, Kansas.

Charles B. Norris

Mechanical Engineer,

Development and Maintenance of

Plants.

Haskelite Manufacturing Corporation,

Grand Rapids, Michigan. 
Robert C. Palmer

F. IV. Peters

Robert E. Prince

Don L. Quinn

S. W. Schorger

(. V. Sweet

Edwin Sutermeister

O. I. Sponsler

Louis Suetter
Chief Chemist,

The Newport Company,

Pensacola. Florida.

J. Aron \& Company, Inc.,

95 Wall Street.

New York. New York.

Superintendent,

Adams and Elting Company,

Chicago, Illinois.

Manager Research Department,

Chicago Mill \& Lumber Company,

Chicago, Illinois.

Chemist.

The Burgess Laboratories,

Madison. Wisconsin.

In Charge Lumber and Drying

Research.

Forest Research Institute.

Dehra Dun. U. P. India.

Chief Chemist,

S. D. Warren Company,

Cumberland Mills, Maine.

Research Fellow,

Stanford University,

Palo Alto, California.

'Technical Expert,

W. H. Coye Organization,

Grand Rapids, Michigan. 
Clyde H. Teesdale

.John H. Thickens

Clinton K. 'Textor'

J. R. Watkins

Howard F. Weiss

O. L. E. Weber

Lage Wernsted

James B. Yule
Grand Rapids, Michigan.

Vice President and General Manager, The Meade Fibre Company, Kingsport, 'Tennessee.

Chemical Engineer,

Northwestern Paper Company,

Cloquet, Minnesota.

Research Engineer,

Chicago Mill and Lumber Company, Chicago, Illinois.

'Treasurer,

The Burgess Laboratories,

Madison. Wisconsin.

Vice President and General Manager, Watab Paper Company,

Sartell, Minnesota.

U. S. Forest Service,

Portland, Oregon.

Assistant Engineer,

U. S. Forest Service,

Missoula, Montana. 




\section{LIBRARY OF CONGRESS \\ |||||||||||||||||||||||||||||||||||||||| \\ |||||||||||||||||||||||||||||||||||||||||||||||| \\ 0000898093 ?}

